UNIVERSIDADE DE SÃO PAULO

ESCOLA POLITÉCNICA

DANIEL GARCIA SOUZA PINTO

AVALIAÇÃo dO NÍVEL DE SERVIÇO ASSOCIADO À CAPACIDADE DE UM TERMINAL PORTUÁRIO

SÂO PAULO

2020 
DANIEL GARCIA SOUZA PINTO

\section{AVALIAÇÃO DO NÍVEL DE SERVIÇO ASSOCIADO À CAPACIDADE DE UM TERMINAL PORTUÁRIO}

\section{Versão Corrigida}

Dissertação apresentada à Escola Politécnica da Universidade de São Paulo para obtenção do Título de Mestre em Ciências.

Área de Concentração: Engenharia Naval

e Oceânica

Orientador: Prof. Dr. André Bergsten Mendes 
Autorizo a reprodução e divulgação total ou parcial deste trabalho, por qualquer meio convencional ou eletrônico, para fins de estudo e pesquisa, desde que citada a fonte.

Este exemplar foi revisado e corrigido em relaçalo á versāo original, sob responsabilidsde única do autor e com a anuência de seu crientador.

são Paulo, 26 de Qutu, bre de 20aco

Assinatura do autor:

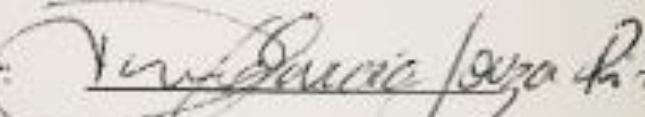

Assinatura do crientador: Al Ux Zs

Pinto, Daniel Garcia Souza

Avaliação do Nivel de Serviço Associado à Capacidade de um Terminal

Portuário / D. G. S. Pinto -- versã̃o corr. -- São Paulo, 2020.

$106 \mathrm{p}$

Dissertação (Mestrado) - Escola Politécnica da Universidade de São Paulo. Departamento de Engenharia Naval e Oceânica.

1.Simulação de Eventos Discretos 2.Nivel de Serviço 3.Terminal Portuário 4.Modelagem Matemática I.Universidade de São Paulo. Escola Politécnica. Departamento de Engenharia Naval e Oceânica II.t. 


\section{DEDICATÓRIA}

À minha família e noiva, por serem as pessoas mais importantes da minha vida e motivos da minha dedicação

E a todos que, de alguma forma, contribuíram para a realização deste sonho. 


\section{AGRADECIMENTOS}

A Deus, primeiramente, por estar presente em todos os momentos da minha vida e que permitiu ao longo dessa jornada a realização de um sonho.

Em especial aos meus pais Joubert Souza Pinto Filho e Regina Celi Garcia Pinto, pelo carinho, pela compreensão, pelo apoio e incentivo, e por nunca deixarem de acreditar, até mesmo nas horas mais difíceis dessa etapa tão importante da minha vida.

Aos meus irmãos Vinícius Garcia Souza Pinto e Joubert Garcia Souza Pinto pelos conselhos e por me inspirarem caráter, sucesso e perseverança.

À minha companheira, melhor amiga e noiva, Andrea Paola Barcellos Covre, pelo companheirismo e compreensão nos momentos em que estive distante, que não foram poucos.

A toda a equipe da CSN, em especial ao meu gestor, colega da USP e amigo Leonardo Dutra Coutinho pela atenção despendida a mim na realização deste trabalho e na minha jornada profissional.

Agradeço também ao meu orientador, André Bergsten Mendes, pela colaboração e pelas orientações dispensadas a mim, não somente durante a execução deste trabalho, mas como em todo o curso de mestrado em engenharia naval. O senhor tem se revelado um excelente ser humano.

Enfim, agradeço aos bons e velhos amigos da USP, Newton Pereira, João Netto, Rodolfo Silva, Daniel Mota, Thiago Brito, Lânia Oliveira, Afonso Medina e aos demais que contribuíram de alguma forma para a realização dessa conquista. 
"Seja a mudança que você quer ver no mundo"

M. Gandhi 


\section{RESUMO}

O presente trabalho se propõe, fundamentalmente, a descrever toda cadeia logística integrada da CSN, desde a operação de descarga de redutores no Porto de Itaguaí, até o abastecimento da Usina Presidente Vargas - UPV no município de Volta Redonda, identificando todos os gargalos operacionais no processo, e propondo uma solução para diminuição da fila de navios sem comprometer o atendimento da siderurgia. Neste estudo foi identificado que as filas geradas no porto de Itaguaí, oriundas dos navios de carvão, coque e $\mathrm{PCl}$, têm onerado a companhia do ponto de vista econômico. Partindo desse pressuposto é que foi desenvolvido um modelo de simulação, com o objetivo de testar as melhores configurações de encomenda de insumos que minimizem as filas de navios e garantam a operacionalidade da UPV. Foram testados cenários de demanda que podem propiciar um melhor entendimento do comportamento da cadeia logística integrada.

Os principais parâmetros estudados foram: o tempo de fila dos navios no terminal bem como a estadia completa dos navios no sistema, os lead times dos produtos encomendados pela usina e a variação dos estoques dos produtos. Os resultados obtidos demonstram que a ferramenta de simulação aplicada no contexto de identificação de gargalos e compreensão real dos problemas logísticos, possibilitam realizar análises e direcionar os gestores das empresas em suas tomadas de decisões.

Palavras-chave: Simulação de eventos discretos, nível de serviço, carvão, coque e $\mathrm{PCl}$, capacidade portuária. 


\begin{abstract}
The present work intends to describe all the integrated logistics chain of CSN, the discharging operation of reducers in the Port Itaguaí, for the supply of the Usina Presidente Vargas, in the city of Volta Redonda, identifying all operational bottlenecks in the process and therefore propose a solution in order to diminish the vessels queues without compromising the steel industry. Besides that, this study identifies that in the Port of Itaguaí, the queues generated from coal, coke and $\mathrm{PCl}$ vessels have harmed the company. Having this scenario in mind, it was developed a simulation model whit the objective of testing the best way to order feedstock that minimize vessels queues and hence guaranteeing the UPV's operability. Demand scenarios were tested that can provide a better understanding of the behavior of the integrated logistics chain.

The main studied parameters were: queu of the vessels at the terminal as well as the complete stay of the vessels in the system, the lead time of the products ordered by the plant and the variation in the stocks of the products. The results obtained demonstrate that the simulation tool applied in the context of identifying bottlenecks and real understanding of logistical problems, make it possible to carry out analyzes and direct company managers in their final decision.
\end{abstract}

Key Words: Discrete events simulation, service level, coal, coke and PCI, port capacity. 


\section{LISTA DE FIGURAS}

Figura 1 - llustração gráfica do efeito chicote numa cadeia de suprimentos fictícia ..24

Figura 2 - Algumas compensações logísticas generalizadas .26

Figura 3 - Quanto maior e mais complexo o sistema, maior a aplicabilidade da simulação .30

Figura 4 - Capacidade de produção e demanda mundial de aço .35

Figura 5 - Berço de Atracação TECAR. .37

Figura 6 - Terminal de Cargas TECAR .38

Figura 7 - Descarregadores de Navios 39

Figura 8 - Empilhadeira .40

Figura 9 - Pátios de Estocagem 41

Figura 10 - Recuperadora .42

Figura 11 - ECV Estação de Carregamento de Vagões 43

Figura 12 - Linha do tempo médio dos navios. .44

Figura 13 - Metodologia de simulação. 49

Figura 14 - Representação do Sistema Portuário .50

Figura 15 - Cadeia Logística integrada porto e usina CSN .51

Figura 16 - Fluxograma do subsistema de chegada de navios .53

Figura 17 - Fluxograma do subsistema de transferência navio terminal .54

Figura 18 - Fluxograma do subsistema de armazenagem .55

Figura 19 - Fluxograma do subsistema de transferência terrestre .56

Figura 20 - Fluxograma do subsistema do transporte porto usina .57

Figura 21 - Fluxograma do subsistema pátio usina. .57

Figura 22 - Plataforma do modelo computacional Port Discharge .58

Figura 23 - llustração do modelo computacional do subsistema de chegada de navios

Figura 24 - Sistema de armazenagem e despache terrestre. .59

Figura 25 - Animação do modelo computacional 60

Figura 26 - Output dos resultados do modelo computacional 61

Figura 27 - Gráfico com o tamanho dos navios movimentados no terminal. 64

Figura 28 -Histograma de tempos médio em fila dos navios .65

Figura 29 - Taxa Comercial dos Navios .66

Figura 30 - Taxa Efetiva dos Navios 
Figura 31 - Distribuição estatística que melhor representa a taxa comercial de descarga do Terminal.

Figura 32 - Distribuição estatística que melhor representa a taxa efetiva de descarga do Terminal .68

Figura 33 - Histograma do tempo de manobras dos navios .69

Figura 34 - Histograma do tempo de pré-operação dos navios no berço. .70

Figura 35 - Histograma de tempo de operação dos navios no berço .71

Figura 36 - Distribuição estatística que melhor representa o tempo de operação do navio .71

Figura 37 - Gráfico do tempo de operação do processo de recarga de trens ...........72

Figura 38 - Gráficos com a capacidade de carga dos trens por produtos .................73

Figura 39 - Percentual das faixas de probabilidades do lead time de $\mathrm{PCl}$................75

Figura 40 - Percentual das faixas de probabilidades do lead time de carvão.............75

Figura 41 - Percentual das faixas de probabilidades do lead time de coque..............76

Figura 42 - Estoque inicial porto e usina ...................................................... 78

Figura 43 - Nível de ocupação de estoque (cenário 1) ........................................... 83

Figura 44 - Distribuição de chegada de navios por produtos (cenário 1) ..................84

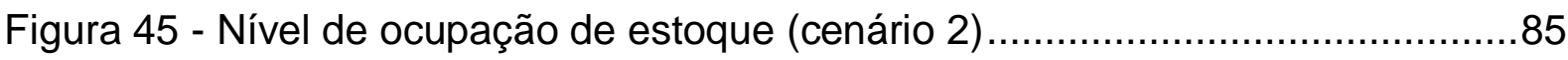

Figura 46 - Análise de Sensibilidade - Estoque de Segurança do Cenário 2 .............90

Figura 47 - Análise de Sensibilidade - Aumento de Capacidade de Estoque do Cenário 2 .93 


\section{LISTA DE TABELA}

Tabela 1 - Exemplo do banco de dados obtidos através dos SOF's 63

Tabela 2 - Média das Taxas Comerciais e Efetivas dos Produtos. .67

Tabela 3 - Consumo médio diário da usina . .73

Tabela 4 - Tabela de premissas cenário base ....................................................77

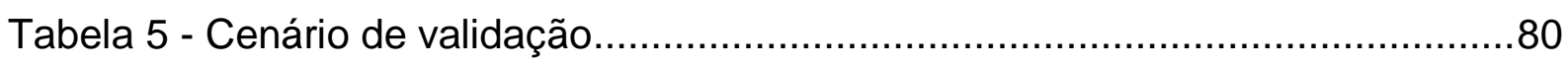

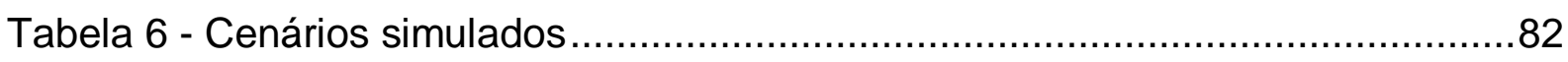

Tabela 7 - Análise de sensibilidade - Estoque de Segurança do Cenário 2 ............88

Tabela 8 - Análise de sensibilidade - Estoque de Segurança do Cenário 2 .89

Tabela 9 - Análise de sensibilidade - Aumento de Capacidade de Estoque do Cenário 2 


\section{SUMÁRIO}

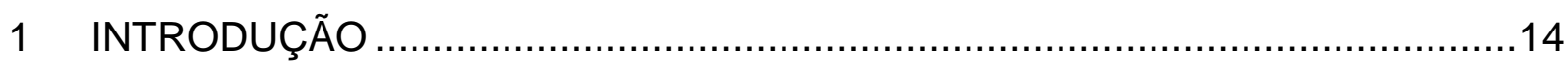

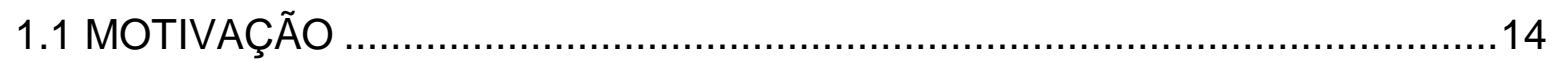

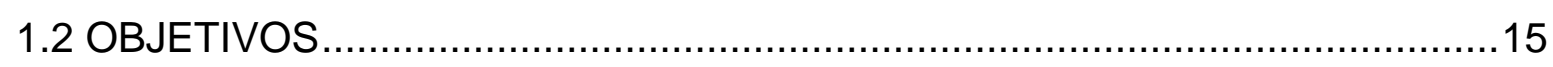

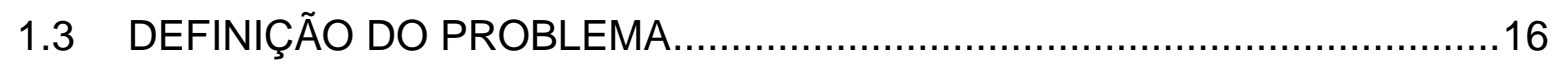

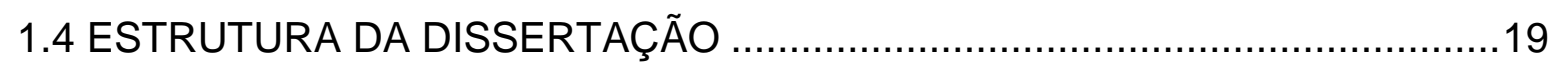

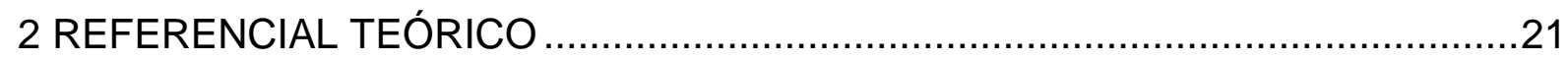

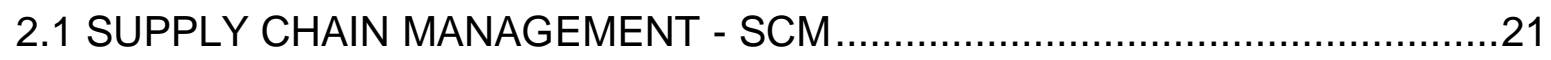

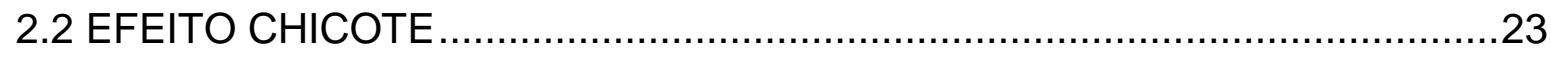

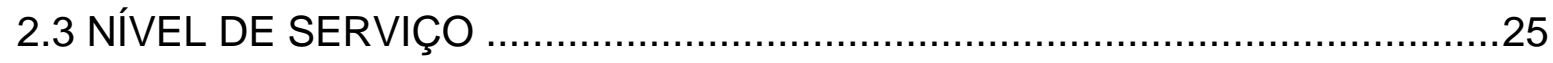

2.4 DIMENSIONAMENTO DE TERMINAL PORTUÁRIO …...............................27

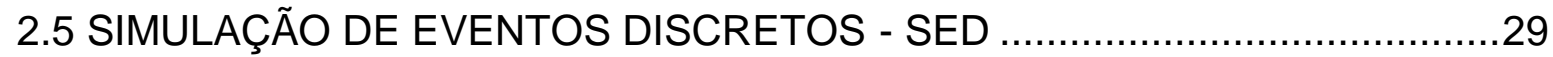

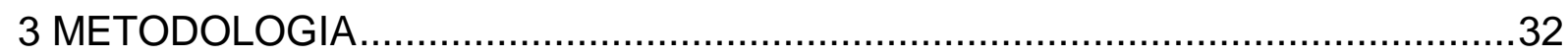

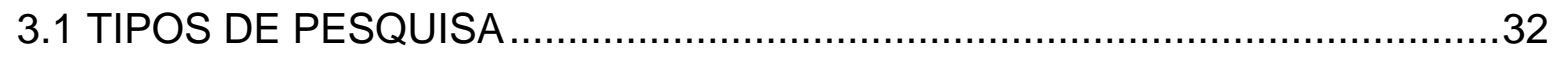

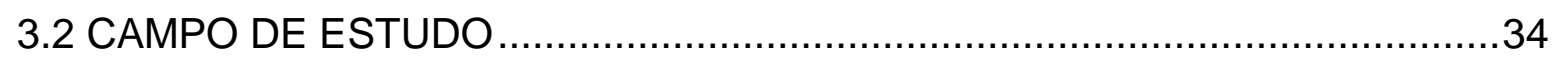

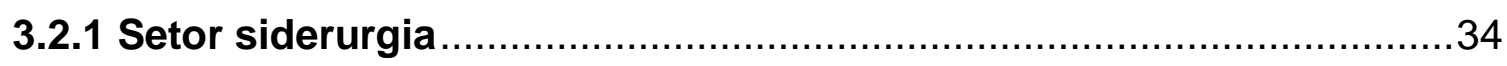

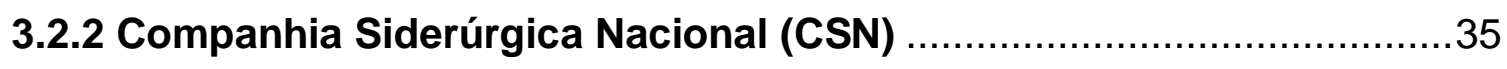

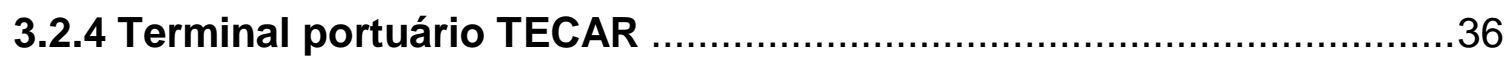

3.2.5 Atividades operacionais do terminal tecar .......................................

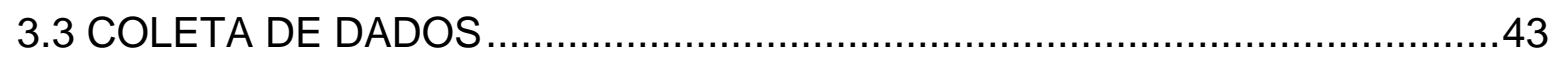

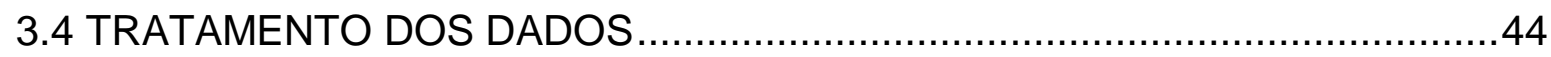

3.5 DESENVOLVIMENTO DO MODELO COMPUTACIONAL ….......................45

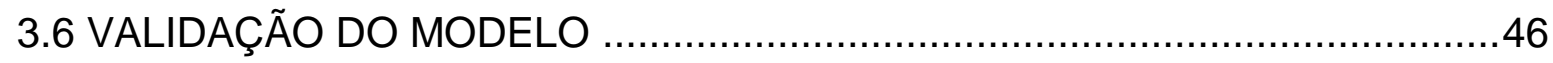

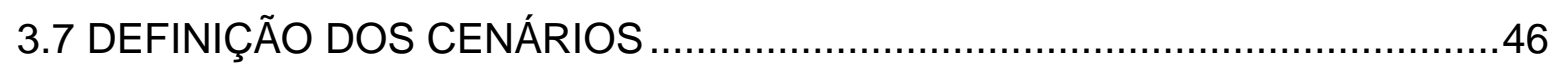

4 DESENVOLVIMENTO DO MODELO COMPUTACIONÁL.......................................48

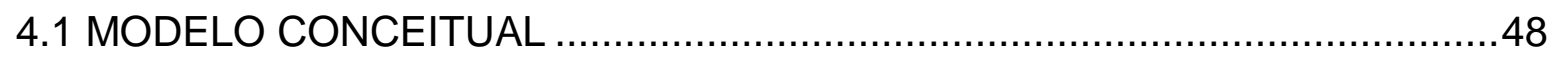

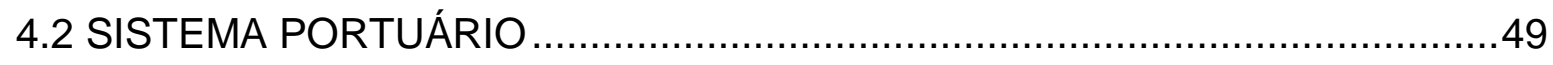


4.2.1 Subsistema chegada de navios

4.2.2 Subsistema transferência navio terminal..........................................53

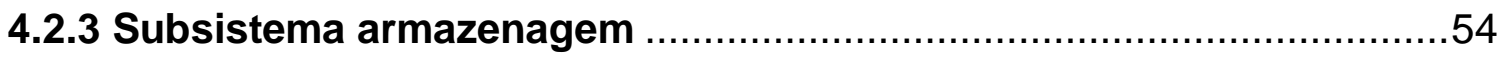

4.2.4 Subsistema transferência terrestre ………….................................5

4.2.5 Subsistema transporte porto usina ………....................................56

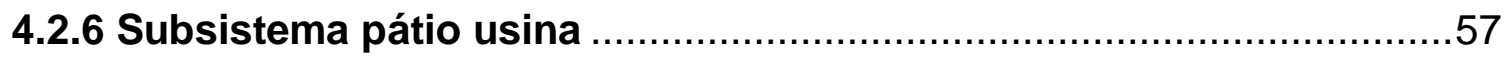

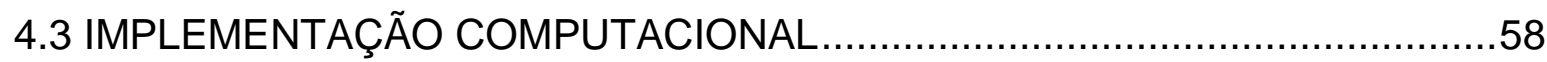

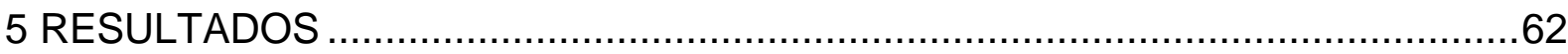

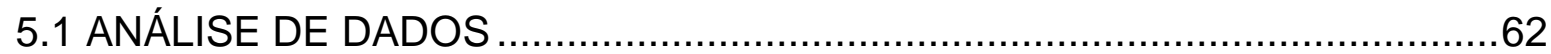

5.2 CENÁRIO BASE

5.3 RESULTADO DE VALIDAÇÃO ……………….......................................

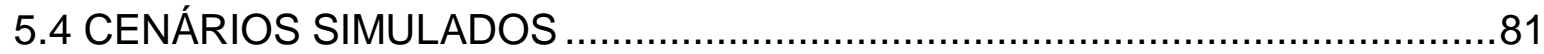

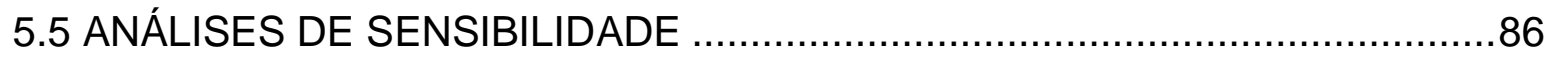

5.5.1 Análise de sensibilidade variando o estoque de segurança ...............87

5.5.2 Análise de Sensibilidade Aumento de Pátio .......................................91

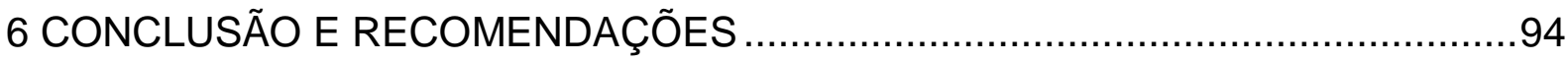

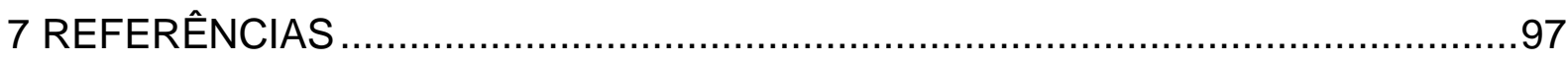

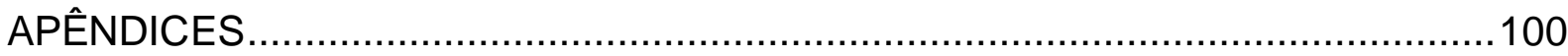

APÊNDICE A - Modelo do documento, Statment of Facts - SOF ......................100

APÊNDICE B - Modelo do Documento, Notice of Readiness - NOR …...............101

APÊNDICE C - Questionário 1) Processo de Abastecimento UPV .....................102

APÊNDICE D - Questionário 2) Processo de Abastecimento UPV ......................105 


\section{INTRODUÇÃO}

Segundo CAMPOS (1999), qualquer decisão gerencial, em qualquer nível, deve ser conduzida para solucionar um problema, lembrando sempre que problema é o resultado indesejável de um processo.

É necessário que nós compreendamos que nenhuma decisão gerencial deveria ser autorizada sem que fosse competentemente suportada por uma análise de processo baseada em fatos e dados, através do método de análise e solução de problemas (CAMPOS, 1999).

Podemos compreender então que, as empresas possuem problemas que as privem de obter melhor produtividade, qualidade em seus produtos, além de prejudicar sua posição competitiva.

Quando se trata de problemas de alta complexidade, de grande relevância para as empresas e impacto direto nos resultados de um sistema, como a melhora do nível de serviço associado a capacidade de um terminal portuário, estes ganhos e perdas podem ser desastrosos se mal administrados.

Portanto, entende-se que existe a necessidade de bom emprego de uma metodologia cientifica, a fim de identificar os gargalos e oportunidades em um sistema portuário, para realização das análises e tomadas de decisões. Este trabalho apresenta as condições necessárias para aplicação dessa ferramenta e, se propõe a fornecer os subsídios para isto.

\subsection{MOTIVAÇÃO}

O modelo de custos que compõe as operações de descarga de granéis em um terminal portuário, se dá pela razão entre os gastos totais e a movimentação total da carga em toneladas. Levando em consideração que os custos portuários têm aumentado ao longo do tempo, cabe um estudo que investigue possíveis custos que hoje impactam no desempenho financeiro portuário, a fim de gerar mais valor às operações portuárias no terminal da CSN. Dentre esses custos, o que mais impacta no porto é o custo advindo da demurrage, que é uma taxa de sobreestadia do navio no terminal. Esse valor é referente à quantia paga ao armador pelo afretador do navio, 
em virtude de o descarregamento do navio ter sido realizado em um tempo superior ao permitido no Voyage Charter Party, contrato firmado entre ambas as empresas.

Um dos motivos que agrava a elevação da estadia do navio no terminal, são as filas geradas em detrimento do nível de serviço oferecido aos navios no porto, isso é refletido pela taxa de ocupação de berço, bem como o número de navios em fila aguardando para atracar.

Deste modo, a motivação para o desenvolvimento deste estudo, é criar uma ferramenta computacional que permita testar cenários de demanda que minimizem esses custos gerados pela sobreestadia dos navios no porto e, consequentemente, aumentar o nível de serviço do terminal.

\subsection{OBJETIVOS}

O objetivo desta pesquisa é propor uma forma para melhorar a assertividade na encomenda de matérias primas descarregadas em um terminal portuário para abastecimento e atendimento de uma indústria siderúrgica, considerando as variabilidades na demanda de cada produto, a taxa de consumo da usina, bem como as características operacionais do porto. Deste modo, esse trabalho deve responder à seguinte pergunta: Qual é a melhor forma de receber os produtos no porto de Itaguaí, de forma a minimizar a fila de navios no terminal e, aumentar o seu nível de serviço frente à capacidade já instalada do sistema portuário?

Para isso, todos os elos da cadeia logística de abastecimento da usina são modelados, o que inclui o sistema portuário, desde o subsistema de descarga dos navios, passando para o subsistema de transbordo e armazenagem, até o subsistema do pátio de recepção de produtos na usina e sua taxa de consumo diária.

Foram identificados os componentes críticos do sistema, que podem impactar na geração de fila de navios e no aumento do custo portuário. Para isso foi realizada uma consulta junto às diversas áreas da empresa que compreendem o sistema portousina, na busca de identificação dos gargalos, e das restrições operacionais e comerciais que deverão estar incorporadas ao modelo. 
Cenários de demanda foram simulados buscando representar esses efeitos, além de alternativas que minimizem a fila de navios e consequentemente o custo advindo dessa sobreestadia dos navios no terminal. Deste modo, pretendeu-se com essa pesquisa orientar a tomada de decisões sobre as melhores condições para a aquisição do mix de produtos destinados ao atendimento da usina siderúrgica.

Assim, o objetivo geral deste trabalho é desenvolver uma ferramenta computacional para clarificar toda compreensão do problema proposto, bem como os detalhes advindos da simulação de eventos discretos. Como objetivos específicos apresentamse: avaliar a encomenda dos insumos das usinas alterando o nível de estoque de segurança dos produtos, avaliando o comportamento da fila de navios no terminal, realizar testes de hipóteses a partir da modificação das variáveis compostas no modelo e geração de cenários a fim de buscar possíveis soluções.

Importante salientar que a construção da sequência de análise dos problemas portuários e o modelo desenvolvido nessa dissertação, podem ser aplicados a outros terminais com características semelhantes aos de descarga de carvão e outros insumos siderúrgicos.

\subsection{DEFINIÇÃO DO PROBLEMA}

Um dos temas de extrema relevância e que há muito tempo serve de estudos para o planejamento e gestão portuária, está diretamente relacionado ao nível de serviço de um terminal. Aliado a isso, os sistemas portuários, muitas das vezes já possuem sua capacidade de infraestrutura instalada e, salve algumas exceções, provém de enormes dificuldades de ampliação.

O desenvolvimento da indústria naval permitiu que novos navios ficassem cada vez maiores e que fossem encontradas novas alternativas mais eficientes para realizar 0 transporte (PEREIRA, 2012).

A partir da breve exposição acima, pode-se relacionar que o aumento e desenvolvimento dos navios juntamente com o aumento das demandas trouxeram enormes dificuldades para os terminais que hoje detém o seu layout operacional já 
pré-definidos. Aumentar o nível de serviço, que tem a fila de navios como principal indicador portuário, se torna o principal desafio e motivo desse trabalho de pesquisa.

Não há uma certeza quanto ao surgimento das filas nem mesmo uma data ou algum marco que caracterize expressamente sua origem. "Entretanto, historiadores e pesquisadores admitem que as filas nasceram a partir da observação do modo como os índios da América caminhavam em terras inimigas, pois eles andavam uns atrás dos outros onde o primeiro tinha o trabalho de abrir a mata para os demais integrantes, e o último apagava as pegadas para que seu inimigo não percebesse sua passagem naquele território, daí o nome Fila Indiana" (BORTOLOTTO, 2014).

Com o desenvolvimento econômico mundial, a urbanização e a concentração da população nas cidades, assume-se que a humanidade aprendeu a se organizar em filas, desenvolvendo técnicas para mitiga-las e minimizar seus impactos.

Sree e Palaniammal (2014) informa que a partir do primeiro modelo de filas, desenvolvido por Erlang (1909), muitos trabalhos foram relatados em literatura sobre modelos de filas e suas aplicações.

A partir do estudo da formação das filas e suas características, através das fórmulas matemáticas, foi instituída a teoria das filas como um método analítico.

$\mathrm{Na}$ atualidade, com as empresas brasileiras buscando cada vez mais uma melhor eficiência em sua logística, surgem crescentes desafios para quem atua na área portuária, enfrentando grandes filas em seus terminais e com alto índice de ocupação dos berços de atracação, tudo isso aliado ao fato de que o manuseio de produtos traz problemas adicionais de estoques e qualidade nos processos pertinentes. Consequentemente, as empresas têm que estar preparadas para estes desafios.

Segundo Gross e Harris (1974), um sistema de filas pode ser definido como clientes chegando, esperando pelo serviço e saindo do sistema após terem sido atendidos. "Clientes", em teoria de filas, é um termo genérico, aplicando não somente a pessoas; um cliente pode ser um avião esperando para pousar, um programa computacional em espera ou, como no caso desta pesquisa, um navio esperando para atracar.

Pode-se, então, reforçar que a fila, tal como a conhecemos, é a melhor forma de organizar recursos quando a demanda supera a oferta. 
Muitas das vezes, a tendência dos terminais portuários brasileiros é a indução das filas de navios decorrentes da maior taxa de ocupação do terminal e da maior utilização do ativo disponível. Consequentemente, as filas geradas pelos navios oneram os processos operacionais, além de proporcionar mau atendimento aos clientes. Este é o principal trade off entre nível de serviço e o uso do ativo disponível.

Deste modo, conviver com esse problema de elevado tempo de espera em fila dos navios, em terminais portuários, é desgastante para os gestores da área, pois estes têm que ficar se justificando das reclamações dos clientes e dos relatórios de custos relativos a demurrage advindos de suas diretorias.

Juliá (2010) ilustra que demurrage é a multa expressa em dólares que a empresa deve pagar a cada navio que excede o tempo máximo permitido em contrato para carregar no porto. Essa multa também é aplicada na descarga de produtos e outros tipos de cargas dos navios, estipulados em contratos com as empresas de navegação.

Atualmente, os modelos gerenciais para definir os custos referentes aos dias dos navios em fila são constituídos de metodologias específicas de teoria de filas, simulações de eventos discretos e técnicas de otimização para definir janelas de atendimento (Lay days) que, além de proporcionar melhorias de qualidade em seus serviços, permitem um crescimento tanto técnico quanto motivacional no ambiente de trabalho.

A análise de um determinado processo, em primeiro lugar, busca um conhecimento mais profundo e específico, permite uma melhor adequação dos recursos, busca encontrar falhas e obter melhorias. No mundo competitivo em que estamos vivendo, as melhorias são fundamentais para a competição, permitindo a sobrevivência da empresa e o aumento da lucratividade.

Este trabalho se propõe, fundamentalmente, a descrever toda cadeia logística de descarga de carvão, coque e PCI no terminal da CSN em Itaguaí, juntamente com o sistema de armazenamento dos produtos nas áreas de estocagem dos pátios e despacho desses insumos, via ferrovia para abastecimento da Usina Presidente Vargas - UPV, em Volta Redonda. O trabalho busca identificar melhorias no processo, 
propondo uma solução para diminuição de fila de navios sem comprometer o atendimento da siderúrgica UPV.

Essa descrição de toda a cadeia será representada através de um modelo de simulação de eventos discretos, o qual permitirá entender o problema como um todo, testar cenários com alteração das variáveis que irão compor esse sistema e estudar o impacto frente a capacidade do mesmo, além de, propor políticas de melhorias.

O objetivo geral desse estudo é elaborar uma proposta de melhoria, advinda da análise do processo de toda cadeia de suprimentos, agregando valor adicional à gestão integrada da companhia, contribuindo de forma significativa com a redução dos custos relacionados à fila de navios, dando maior segurança nas tomadas de decisões e maior confiabilidade do sistema, e aumento do nível de serviço perante os seus clientes.

\subsection{ESTRUTURA DA DISSERTAÇÃO}

A sequência desta pesquisa visa ilustrar, de forma didática, a compreensão do leitor sobre: os problemas e limitações existentes em terminais portuários, o desenvolvimento do modelo de simulação como ferramenta analítica para solução de problemas, a importância do mapeamento e entendimento de um sistema logístico integrado, uma abordagem interessante sobre análises de dados em um porto além, das conclusões e recomendações desse trabalho.

O capítulo 2 refere-se a toda sustentação ao desenvolvimento da pesquisa, baseada na literatura existente, que dará o suporte para todo trabalho e sua aplicação.

No capítulo 3, o leitor encontrará a apresentação do método aplicado, assim como a estrutura de trabalho e onde tal método foi empregado. A aplicação dos conceitos e 0 uso da metodologia relatados no capítulo 2 e 3 , isto é, a utilização do sistema de simulação de eventos discretos aplicado em uma cadeia logística, a fim de trazer alternativas para solucionar um problema portuário, será encontrado no capítulo 4 , com a configuração de todo desenvolvimento do modelo. 
No capítulo 5 são apresentadas todas as análises realizadas, através do levantamento de dados reais da empresa, e os resultados encontrados através do modelo desenvolvido. Cenários foram simulados através da análise de sensibilidade do modelo, a fim de possibilitar alternativas de gestão e até mesmo tomadas de decisões.

Por fim, o capítulo 6 , descreve toda a conclusão e as recomendações dessa dissertação. 


\section{REFERENCIAL TEÓRICO}

Este capítulo apresenta a revisão bibliográfica construída através dos aspectos científicos que fundamentam o desenvolvimento desta dissertação. Toda revisão bibliográfica deste capítulo, refere-se à cadeia logística, ao sistema portuário e seus aspectos de dimensionamento associados ao nível de serviço, bem como a aplicação de técnicas de simulação de eventos discretos para solução de problemas.

Silva e Menezes (2001) reforçam que essa é uma das etapas mais importantes de um projeto de pesquisa. A revisão de literatura refere-se à fundamentação teórica na qual irá se basear o desenvolvimento do tema e a resolução do problema de pesquisa. Por meio da análise da literatura publicada pode-se traçar um quadro teórico, e fazer a estruturação conceitual, que dará sustentação ao desenvolvimento da pesquisa.

\subsection{SUPPLY CHAIN MANAGEMENT - SCM}

Podemos descrever que supply chain é o cumprimento das operações padronizadas e a atuação de uma logística integrada das áreas de: Compras, Transportes, Armazenagem, Manuseio de Produtos e Distribuição. É um processo onde se tem todas as atividades de movimentação e armazenagem, que facilita o fluxo de produtos, desde o ponto de aquisição das matérias-primas até o ponto de consumo final do produto, juntamente com a gestão de informação que direciona os produtos em circulação.

A Cadeia de Suprimentos abrange todas as atividades relacionadas com o fluxo e transformação de mercadorias, desde o estágio de matéria-prima (extração) até o usuário final, bem como os respectivos fluxos de informação (BALLOU, 2006).

Para alcançar estes objetivos, a área de supply chain deve se caracterizar como proativa, objetivando a melhoria contínua de seus processos e desenvolvendo uma gestão eficaz profunda de toda cadeia logística integrada, assegurando a continuidade operacional, o nível de satisfação do cliente, as boas práticas na redução dos custos e visando sempre maximizar o processo produtivo, em conformidade com as diretrizes da Companhia, contribuindo para a rentabilidade e prosperidade operacional. 
Ballou (2006) destaca que oportunidades para a melhoria dos custos ou serviços aos consumidores são caraterizadas pela coordenação e colaboração entre os integrantes desse canal, pela interação entre as funções da área comercial, logística e produção no âmbito da empresa, nos pontos em que algumas atividades essenciais da cadeia de suprimentos podem não estar sob o controle direto dos especialistas em logística.

É essencial essa colocação pois podemos observar, no meio coorporativo, que algumas decisões são tomadas sem que haja consulta aos especialistas, sejam eles das áreas de logística, suprimento ou comercial, além de, na maioria das vezes, não haver elos bem definidos na cadeia, justamente pela ausência de envolvimento entre as áreas e de coordenação dos integrantes do processo.

Figueiredo e Arkader (1998) reiteram que o conceito de supply chain management surgiu como uma evolução natural do conceito de logística integrada. Enquanto a Logística Integrada representa uma integração interna de atividades, o supply chain management representa sua integração externa, pois estende a coordenação dos fluxos de materiais e de informações aos fornecedores e ao cliente final.

No caso de empresas que dominam a cadeia logística, e que tem definido os fluxos de suas atividades internas, bem como os controles de fluxos de informações de fornecedores e clientes, o domínio de todo o sistema acarreta na oferta de níveis de serviços mais satisfatórios.

Perez-Franco (2016) alerta que, muitas vezes, não se tem critérios específicos para avaliar se os objetivos perseguidos pela estratégia de cadeia de suprimentos foram alcançados. Certamente, não se sabem todos os fatos relevantes para o ambiente futuro em que a cadeia de suprimentos funcionará, nem se pode prever com certeza o resultado de várias decisões possíveis que são tomadas a respeito. Segundo PerezFranco (2016) "[...] devido às mudanças contínuas que ocorrem no ambiente da organização, o problema de repensar a cadeia de suprimentos é dinâmico, não estático: as coisas mudarão com o tempo, mesmo que você não faça nada para alterálas. Além disso, como as cadeias de suprimentos tendem a ser grandes em escala e complexas por natureza, as estratégias da cadeia de suprimentos tendem a não ser simples nem fáceis de compreender, e muitas vezes precisamos tomar decisões com base em informações incompletas, inexatas e até incorretas". 
Portanto, as tomadas de decisões devem levar em consideração a integração do sistema e o envolvimento constante das áreas e dos setores da empresa, buscando melhorar as dispersões ao longo da cadeia. Essas dispersões são caracterizadas como efeito chicote.

\subsection{EFEITO CHICOTE}

Coelho et al. (2007) afirmam que um dos problemas estudados e enfrentados por uma SCM é o efeito chicote. Esse efeito é a variação ou a impossibilidade de alinhamento da demanda à oferta. Em outras palavras, o efeito chicote é o resultado de uma expectativa de demanda ou oferta que não se realiza, por diversos motivos, entre elas a incapacidade de prever a demanda dos clientes, e que se propaga por todas as empresas da cadeia, influenciando os níveis de estoques, os tamanhos dos pedidos e a produtividade.

Lee et al. (2004) citam que as informações transferidas a partir de baixo, na forma de ordens, tendem a ser distorcidas e podem confundir os membros no "andar de cima" da cadeia de abastecimento em suas decisões de estoque e produção, fenômeno chamado "Efeito Chicote". As principais causas relacionadas ao efeito são:

- Processamento da Previsão de Demanda;

- Conjunto de Racionamento;

- Ordem de processamento em lote e acúmulo de pedidos;

- Flutuações de Preço;

No cenário competitivo que estamos vivenciando, as empresas procuram estabelecer um estoque de segurança alto para que o nível de serviço seja garantido aos clientes, seja ele interno ou externo. Nesse sentindo os gestores devem ter a sensibilidade e o cuidado de não gerar estoques exagerados, seja de matérias primas ou de produto acabado. 
Chopra e Meindl (2003) reforçam que os gerentes devem começar comparando a variabilidade dos pedidos que recebem de seus clientes com a variabilidade de pedidos que fazem a seus fornecedores.

Lee et. al. (2004) afirmam ainda que os leads times de pedidos longos contribuem para que a ocorra o efeito chicote. Ou seja, é necessário então que esses ciclos de pedidos sejam reduzidos, de forma que o cliente possa se sentir mais seguro em relação à programação efetuada, evitando a sensação de falta de proteção quanto aos estoques.

Segundo Svensson (2005), o efeito chicote indica que a variabilidade no nível de estoques tende a ser maior ao se afastar do ponto de consumo. Sendo que os fatores que o causam podem ser o compartilhamento de informações deficientes e dados de mercado insuficientes, gerando previsões incorretas.

A partir de todos esses conceitos relativos ao efeito chicote, pode ser concluído que o desequilíbrio entre a oferta e a demanda por falta de gerenciamento e desarmonia gera um impacto enorme em toda cadeia logística. Essa variação entre a demanda e a oferta é um dos principais problemas de SCM, gerando resultado na performance financeira de uma empresa.

Figura 1 - llustração gráfica do efeito chicote numa cadeia de suprimentos fictícia

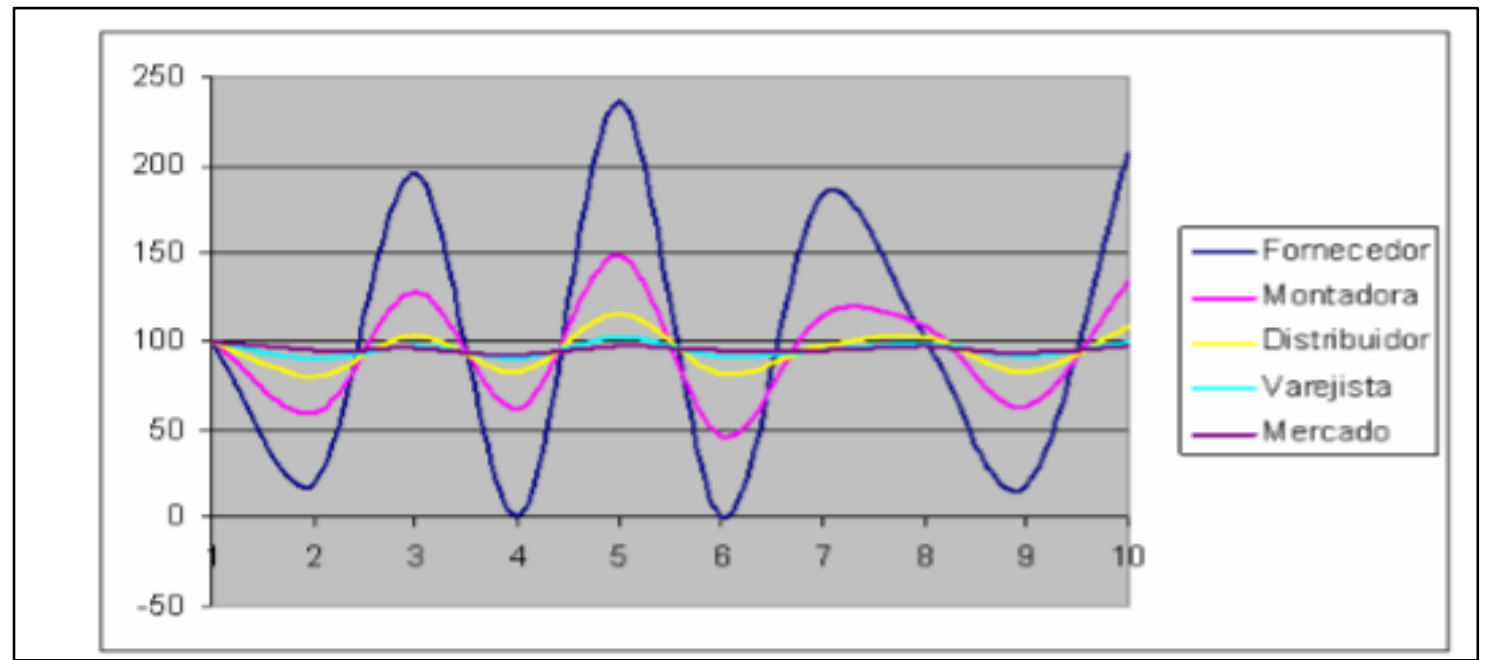

Fonte: Slack et al. (1999) 
A Figura 1 ilustra de forma gráfica e representativa, a variação dos diversos elos da cadeia. Pode ser observado que, enquanto o mercado e os varejistas estão com uma constante na demanda, a variação do fornecedor impacta diretamente a produção e a distribuição da montadora.

No caso de terminais portuários, esse efeito tem um alto impacto sobre a operação do porto como um todo. O desbalanceamento da cadeia logística, caso haja alguma variação nos elos da cadeia, compromete diretamente a fila de navios no terminal. É sabido que, caso o estoque de um terminal esteja em níveis elevados e, a chegada de navios esteja desordenada, inevitavelmente haverá um aumento do número de navios em fila aguardando a redução dos níveis de estoque para poder descarregar suas cargas. Este aumento na fila de navios, consequentemente, irá comprometer o nível de serviço do porto.

\subsection{NÍVEL DE SERVIÇO}

Lee et al. (1997) contextualizam o efeito chicote e listam os problemas adicionais que esse efeito provoca na cadeia logística. As grandes variações na demanda ao longo da Cadeia de Suprimentos podem gerar excesso de estoques, baixo nível de serviço em função da falta de produtos ou excesso de pedidos em carteira, desbalanceamento de capacidade, previsões de demanda ruins, incerteza nos planos de produção e alto custo com as revisões de entregas e horas extras.

Ballou (2006) define como peça central para o escopo e o projeto do sistema logístico a análise de compensação (trade-off), que leva ao conceito do custo total. A compensação do custo é o reconhecimento de que os padrões de custos das várias atividades da empresa frequentemente revelam características que as colocam em conflito mútuo. Gerencia-se esse conflito mediante um equilíbrio entre as atividades de maneira que sejam coletivamente otimizadas.

$\mathrm{Na}$ Figura 2, o autor faz um link dos principais problemas logísticos com a compensação dos custos, onde na figura (a) contempla o problema da determinação de nível de serviço; (b) determinação do número de armazéns em um sistema 
logístico; (c) estabelecendo níveis de estoque de segurança; (d) estabelecendo a sequência de rodadas de produção para itens múltiplos.

Figura 2 - Algumas compensações logísticas generalizadas

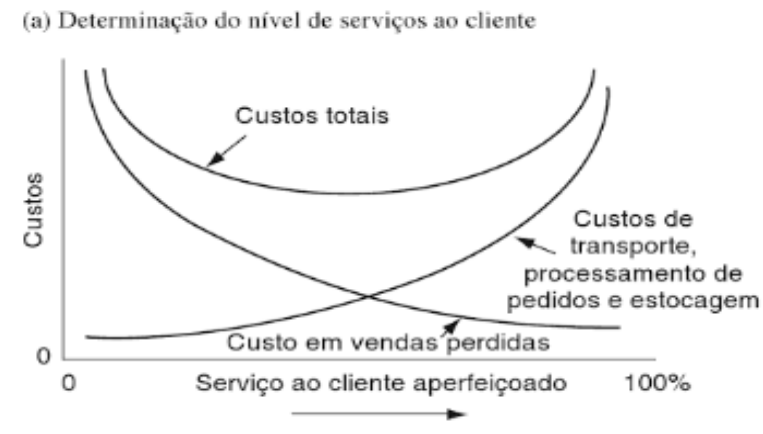

(b) Determinação do número de armazéns em um sistema logístico

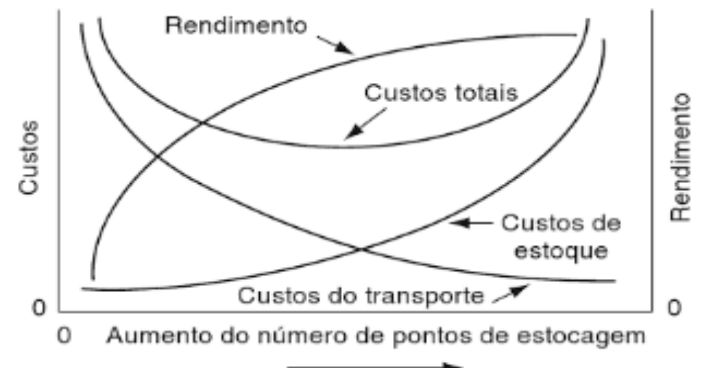

(c) Estabelecendo níveis de estoques de segurança

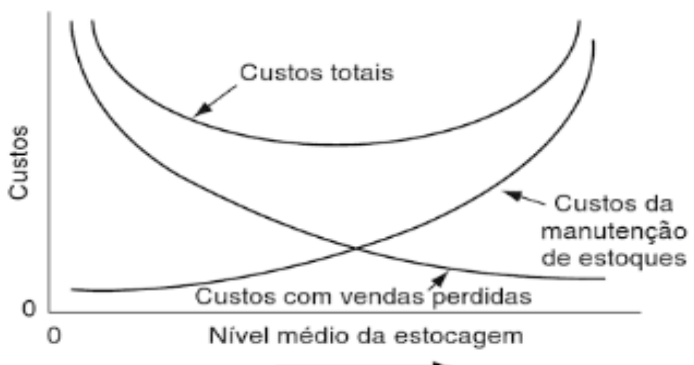

(d) Estabelecendo a sequiência de rodadas de produção para itens múltiplos

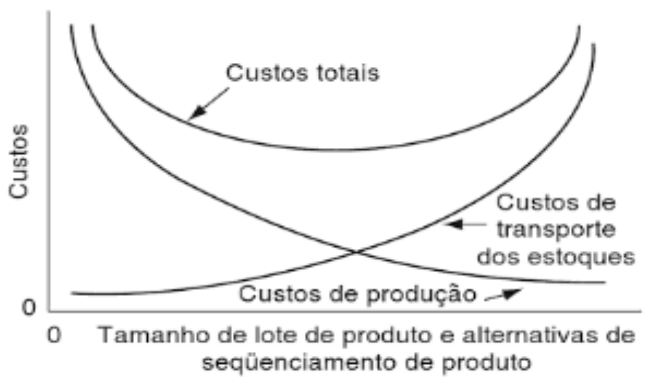

Fonte: Ballou (2006)

$\mathrm{Na}$ figura "a" pode ser observado que a determinação do nível de serviço está inversamente relacionada com a compensação dos custos em vendas perdidas, ou seja, quanto maior o aumento no nível de serviço, menor os custos em vendas perdidas. Por um outro lado, o nível de serviço está diretamente relacionado com os custos de transportes, de processamento de pedidos e de estocagem. A partir do momento que são investidos mais nesses recursos, existe um aumento do nível de serviço.

Juliá (2010) faz uma correlação do nível de serviço com um outro custo, este sim, específico e relacionado aos terminais portuários. Dependendo do atendimento aos navios e, se eles aguardam altos tempos em fila, o baixo nível de serviço oferecido pelo porto é penalizado pela taxa de demurrage. De acordo com Juliá (2010) “[...] A 
definição do melhor cenário que atenda as condições de demurrage e tempo de espera também está relacionada ao nível de serviço que a empresa deseja prestar a seus clientes com relação ao tempo de espera e ao montante que a empresa está disposta a desembolsar com o pagamento de demurrage ao longo dos anos".

Sobre políticas de controle de estoque e, que influenciam no nível de serviço, principalmente quando esse pode ser um gargalo operacional, Leonard e Roy (1995) apud Silva (2010) afirma que o controle de estoque é estudado desde 1913, com Herris. Um bom gerenciamento de estoques equaciona as questões de disponibilidade, nível de serviço e custos de manutenção (Krever et al. 2003). As formas mais comuns de políticas de reabastecimento adotadas na prática são: Revisão continuada e Revisão periódica (Dias, 2003).

Ou seja, nas duas formas de políticas de reabastecimento, a empresa deve entender qual modelo aplicar, se deverá revisar seu abastecimento continuamente ou periodicamente. A decisão deverá ser norteada a partir do entendimento do sistema e de suas especificidades. Fato é que essa decisão é determinante para os fatores críticos de sucesso em uma operação logística integrada.

\subsection{DIMENSIONAMENTO DE TERMINAL PORTUÁRIO}

O transporte marítimo é o tipo de transporte aquaviário realizado por meio de embarcações utilizando o mar aberto como via. Pode ser de cabotagem ou costeira, onde a navegação é realizada entre pontos da costa ou entre um ponto costeiro e um ponto fluvial, ou de navegação de longo curso, navegação entre portos brasileiros e estrangeiros. Os portos marítimos são os terminais onde acontecem a maioria dos processos administrativos, operacionais e de fiscalização destas atividades. É o principal tipo de transporte nas comercializações internacionais e pode transportar diversos tipos de produtos como veículos, cereais, petróleo, alimentos, minérios e combustíveis (ROCHA, 2015).

Lemos (2017) informa que o tipo de transporte marítimo representa a grande maioria do transporte aquaviário. Muitas das vezes essa denominação é usada como sinônimo, e se transforma como o principal tipo de conduza internacional para 
comercialização de diversos produtos, entretanto são pelos mares onde temos cerca de $90 \%$ da mercadoria transportada.

A partir das citações acima, pode-se descrever que o transporte marítimo é uma grande artéria de movimentações de cargas e, o dimensionamento de um terminal é extremamente importante no quesito atendimento desses volumes.

É importante observar que um dos principais dimensionamentos de um empreendimento, prestador de serviço, se deve ao balanceamento entre sua oferta e demanda. Em dimensionamento de terminais portuários, algumas premissas, como a projeção da demanda, devem ser consideradas a fim de determinar:

- Número ótimo de berços;

- A capacidade dos equipamentos para manuseio dos produtos, definido para o terminal;

- Capacidade da área para armazenagem dos produtos;

- Definição dos navios tipos a serem atendidos no terminal;

$\mathrm{Na}$ fase de concepção do terminal portuário é necessário considerar um inesperado aumento de demanda. Setores que operam com commodities são altamente afetados pelos efeitos cíclicos do mercado. Isso reflete também na capacidade dos sistemas se adequarem a atender demandas inesperadas. Deste modo, as empresas devem priorizar a máxima utilização dos seus ativos, buscando aumentar o nível de serviço e baixando os custos em suas operações.

Gualda (1995) diz que o dimensionamento operacional do terminal, em particular, envolve o dimensionamento e o balanceamento de capacidade dos seus diversos componentes, para que se torne necessário utilizar modelos e critérios que permitam e facilitem a elaboração dessas tarefas.

Pereira (2012) explica que a UNCTAD (1985) sugere, para países em desenvolvimento, a taxa de ocupação do berço esteja na faixa de 60\%. No entanto, para terminais privativos, é comum encontrá-los operando com $90 \%$ de taxa de ocupação de berço. 
Mota (2014) ressalta que a gestão de um recurso para se obter a sua máxima ocupação requer não somente a técnica de planejamento adequada, mas também a consideração das incertezas durante o seu uso.

Deste modo observa-se a necessidade de uma boa gestão sobre os ativos, bem como um excelente planejamento a fim de atingir a máxima utilização dos recursos disponíveis em um terminal portuário. A garantia de um bom desempenho é medida pelo nível de serviço e, esse é um dos grandes desafios das empresas quando associados a capacidade dos terminais.

Netto et al. (2015) descreve que em terminais portuários o conceito de capacidade associado ao nível de serviço é algo que pode ser usado com simulação em diversas situações que envolve logística e o planejamento comercial das organizações, pois permite uma visão prática do comportamento real de um sistema, facilitando a compreensão dos gargalos existentes.

\subsection{SIMULAÇÃO DE EVENTOS DISCRETOS - SED}

A simulação de eventos discretos, também conhecida como SED, é uma técnica analítica que se utiliza de ferramentas computacionais a fim de melhorar a capacidade de compreensão de um sistema e no auxílio de tomadas de decisões.

Segundo Chwif e Medina (2015), a simulação além de uma ferramenta de análise de problemas, é uma ferramenta que promove uma melhor compreensão sobre os sistemas, servindo de meio de comunicação entre analistas, gerentes e pessoas ligadas à sua operação.

Os autores ainda afirmam que "quanto mais complexo, dinâmico e aleatório for um problema, maior será a aplicabilidade das ferramentas de simulação" (CHWIF; MEDINA, 2015). 
Figura 3 - Quanto maior e mais complexo o sistema, maior a aplicabilidade da simulação

\begin{tabular}{|c|c|c|}
\hline Problema & Ferramentas & Resultados \\
\hline $\begin{array}{c}\text { Maior } \\
\text { Complexidade } \\
\text { Dinâmica } \\
\text { Aleatoriedade }\end{array}$ & $\begin{array}{c}\text { Simulação } \\
\text { Calculadora } \\
\text { Lápis e Papel } \\
\text { Intuição }\end{array}$ & $\begin{array}{c}\text { Maior } \\
\text { Qualidade } \\
\text { Esforço }\end{array}$ \\
\end{tabular}

Fonte: Chwif e Medina (2015)

O termo simulação, refere-se à criação de modelos que representam um sistema real de forma simplificada e que permitem a experimentação de alternativas, ou, cenários pré-estabelecidos. As análises realizadas com os modelos de simulação possibilitam o entendimento do comportamento do sistema em diversas situações (SILVA, 2012).

Pereira e Laurindo (2007) apud Pereira (2012) explicam que os modelos de simulação são empregados para representar um ambiente real em um modelo virtual. Estes modelos são elaborados através de formulações matemáticas, que devem reproduzir, da maneira mais fiel possível, os efeitos característicos do sistema original. Assim, manipulado o modelo no computador e analisando os resultados, pode-se concluir como os diversos fatores afetarão o desempenho do sistema.

Trazendo a utilização dessa ferramenta para o contexto de sua aplicação em terminais portuários, pode-se descrever que a possibilidade de compreensão real do sistema logístico, permite que, a partir do modelo simulado, seja possível ter uma dimensão clarificada dos problemas e gargalos operacionais. Além do entendimento desses problemas, o modelo permitirá de forma sensível, testar cenários e hipóteses, através de premissas adotadas que, nortearão os gestores das empresas em suas tomadas de decisões. 
Políticas e medidas implementadas, baseada em dados e ciência, através dos resultados provenientes de um modelo matemático, trazem segurança financeira e garantem aumento do nível de serviço. 


\section{METODOLOGIA}

Após uma apresentação dos aspectos teóricos relacionado ao trabalho, descrito no capítulo 2, esse capítulo apresentará toda metodologia abordada e o caminho direcionado no desenvolvimento de toda a pesquisa.

A pesquisa é um trabalho em processo não totalmente controlável ou previsível. Adotar uma metodologia significa escolher um caminho, um percurso global do espírito. O percurso, muitas das vezes, requer ser reinventado a cada etapa. É preciso, então, não somente de regras e sim de muita criatividade e imaginação (SILVA; MENEZES, 2001).

\subsection{TIPOS DE PESQUISA}

Segundo o dicionário Houaiss, "metodologia é o ramo da lógica que se ocupa dos métodos das diferentes ciências".

Cartoni (2007) reforça que a metodologia é a explicação minuciosa, detalhada, rigorosa e exata de toda ação desenvolvida no método (caminho) do trabalho de pesquisa. É a explicação do tipo de pesquisa, do instrumental utilizado (questionário, entrevista), do tempo previsto, da equipe de pesquisadores e da divisão do trabalho, das formas de tabulação e tratamento dos dados, enfim, de tudo aquilo que se utilizou no trabalho de pesquisa.

Considerando-se o critério de classificação de pesquisa proposto por Vergara (2000), quanto aos fins e quanto aos meios, o presente trabalho consiste:

- Quanto aos fins - trata-se de uma pesquisa descritiva, pois expõe características de determinada população, e explicativa, pois visa esclarecer fatores que contribuem para a ocorrência de determinado fenômeno.

- Quanto aos meios - trata-se de um estudo de caso que representa uma estratégia de investigação que examina um fenômeno em seu estado natural, empregando múltiplos métodos de recolha e tratamento de dados sobre uma ou algumas entidades (pessoas, grupos ou organizações). 
Filippini (1997) lista tipos de abordagens de pesquisa, relacionados em sete categorias:

- Levantamento tipo survey: uso de instrumentos de coleta de dados único (em geral, um questionário), aplicado a amostras de grande tamanho, com o uso de técnicas de amostragem e análise e inferência estatística;

- Estudo de caso: análise aprofundada de um ou mais objetos (casos), com o uso de múltiplos instrumentos de coleta de dados e presença da interação entre pesquisador e objeto de pesquisa;

- Modelagem: uso de técnicas matemáticas para descrever o funcionamento de um sistema ou de parte de um sistema produtivo;

- Simulação: uso de técnicas computacionais para simular o funcionamento de sistemas produtivos a partir de modelos matemáticos;

- Estudo de campo: outros métodos de pesquisa (principalmente de abordagem qualitativa) ou presença de dados de campo, sem estruturação formal do método de pesquisa;

- Experimento: estudo da relação causal entre duas variáveis de um sistema sob condições controladas pelo pesquisador;

- Teórico/conceitual: discussões conceituais a partir da literatura, revisões bibliográficas e modelagens conceituais

Após terem sido apresentados os aspectos de pesquisa classificados tanto por Vergara (2000), como por Filippini (1997), o desenvolvimento do trabalho terá a aplicação de um estudo de casos.

Um estudo de caso é uma história de um fenômeno passado ou atual, elaborada a partir de múltiplas fontes de provas, que pode incluir dados da observação direta e entrevistas sistemáticas, bem como pesquisas em arquivos públicos e privados (VOSS; TSIKRIKTSIS; FROHLICH, 2002). É sustentado por um referencial teórico, que orienta as questões e proposições do estudo, reúne uma gama de informações obtidas por meio de diversas técnicas de levantamento de dados e evidências (MARTINS, 2008). 
O estudo de caso contará com a metodologia de simulação de eventos discretos (SED), bem como a utilização dos conceitos correlacionados a supply chain, a fim de identificar melhorias e soluções para o problema proposto.

O trabalho contou também com a compreensão e avaliação de todo processo logístico, por parte de colaboradores da empresa, através do método de pesquisa do tipo survey, pelo meio de um questionário utilizado para adquirir um maior entendimento por parte do processo da cadeia de suprimentos, conforme apêndice $C$ e apêndice $D$.

Neste trabalho, o universo de pesquisa abrange o histórico de dados do processo de manuseio de granéis sólidos do Terminal Portuário de Itaguaí (TECAR), compostos pelos subsistemas de embarque, descarga, transbordo, recarga e logística ferroviária, armazenamento de insumos na usina, bem como, seu consumo diário.

\subsection{CAMPO DE ESTUDO}

\subsubsection{Setor siderurgia}

No atual cenário de desenvolvimento da sociedade, o aço é um dos produtos mais presentes no cotidiano das pessoas, seja nas construções imobiliárias, nos meios de transportes e em bens de consumo em geral, tornando-se muitas vezes imperceptível, mas fundamental para o desenvolvimento econômico das nações (DAUDT, 2014).

Vital para a economia brasileira, o setor siderúrgico respondeu por 109 mil postos de trabalho gerados no país em 2015, de acordo com o Instituto Aço Brasil (IABR). Entretanto, o agravamento da crise política e econômica, a queda global nos preços das commodities e o excedente na produção mundial vêm fazendo com que o segmento registre baixas em oferta, vendas e consumo aparente.

Além dos impactos causados diretamente entre aqueles que dependem dessa atividade para sobreviver, com o fechamento de empregos, há ainda os efeitos indiretos, visto que a área composta por 29 usinas, administradas por 11 grupos empresariais, movimenta uma vasta cadeia de fornecedores (LOURENÇO, 2016). 
Com o aumento crescente do nível de competitividade no mercado siderúrgico, tendo a capacidade de produção mundial excedente em aproximadamente 800 milhões de toneladas conforme Figura 4. Podemos concluir que os players do ramo de siderurgia devem focar em minimizar seus custos, priorizando a excelência operacional e uma boa prestação de serviço a fim de se manterem competitivos, tendo a área de logística podendo contribuir em grande parcela em busca desses objetivos.

Figura 4 - Capacidade de produção e demanda mundial de aço

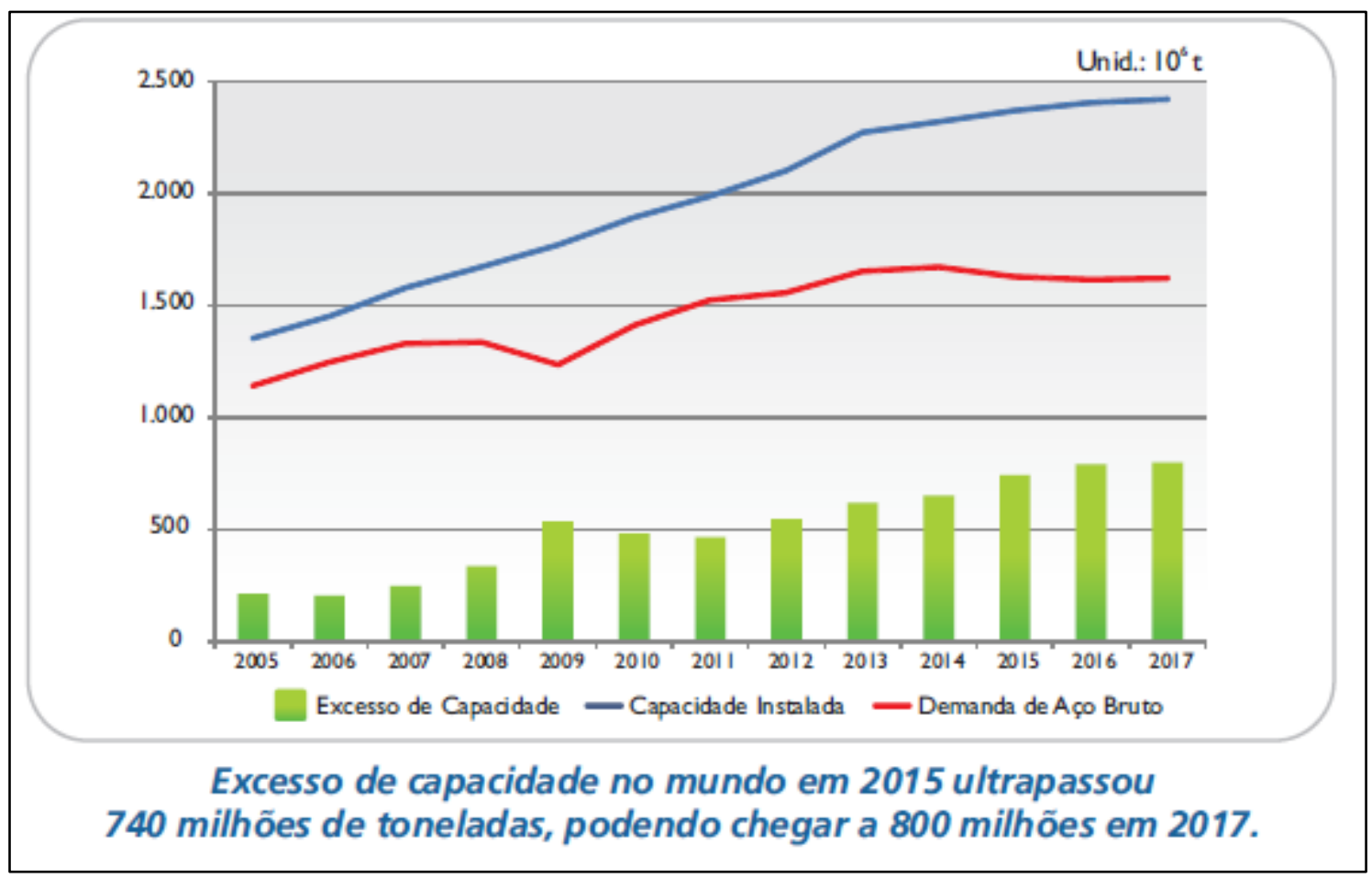

Fonte: Instituto Aço Brasil (2016)

\subsubsection{Companhia Siderúrgica Nacional (CSN)}

Fundada em abril de 1941, a CSN foi a primeira produtora integrada de aço plano no Brasil, um marco no processo de industrialização do país. Seu aço viabilizou a implantação das primeiras indústrias nacionais, núcleo do atual parque fabril brasileiro. Privatizada em 1993, a companhia vem, desde então, modernizando-se e diversificando sua atuação (CSN, 2019). 
A Companhia Siderúrgica Nacional (CSN) é um dos mais eficientes complexos siderúrgicos integrados do mundo e atua com destaque em cinco setores: siderurgia, mineração, logística, cimento e energia. A empresa domina toda a cadeia produtiva do aço atendendo diferentes segmentos da indústria: construção civil, linha branca, produtos para distribuidores e embalagens metálicas.

A CSN administra dois terminais no Porto de Itaguaí, no Rio de Janeiro: o terminal de granéis sólidos (TECAR) e o terminal de contêineres (Sepetiba Tecon).

O TECAR, localizado no Porto de Itaguaí, é o terminal portuário administrado pela CSN Mineração interligado à MRS com capacidade de exportação superior a 42 milhões de toneladas de minério de ferro anual no berço 102. O terminal possui também a capacidade para realizar descarga de até 3,5 milhões toneladas por ano de redutores no berço 101 e ainda a versatilidade de operações de outros granéis por meio do berço 202 (CSN, 2019).

\subsubsection{Terminal portuário TECAR}

O Porto de Itaguaí está localizado em uma região de fácil acesso marítimo, rodoviário e ferroviário. Está situado próximo aos três principais polos econômicos do país, ou seja: 80 Km do Rio de Janeiro; 300 Km de São Paulo; 500 Km de Belo Horizonte.

O TECAR possui uma área total de $732.911 \mathrm{~m}^{2}$, no Porto de Itaguaí, Estado do Rio de Janeiro, e é constituído de um píer de concreto sobre estacas, ligado ao continente por uma ponte de acesso perpendicular ao píer. Sua retro área compreende correias transportadoras, sistema viário interno, pátios de estocagem de granéis, pera ferroviária com silo de carregamento de vagões, além de instalações industriais e administrativas complementares. Todo este complexo realiza a operação de recebimento, estoque e embarque de minério de ferro e descarga, estoque e carregamento de vagões de carvão, coque e PCl. 
Figura 5 - Berço de Atracação TECAR

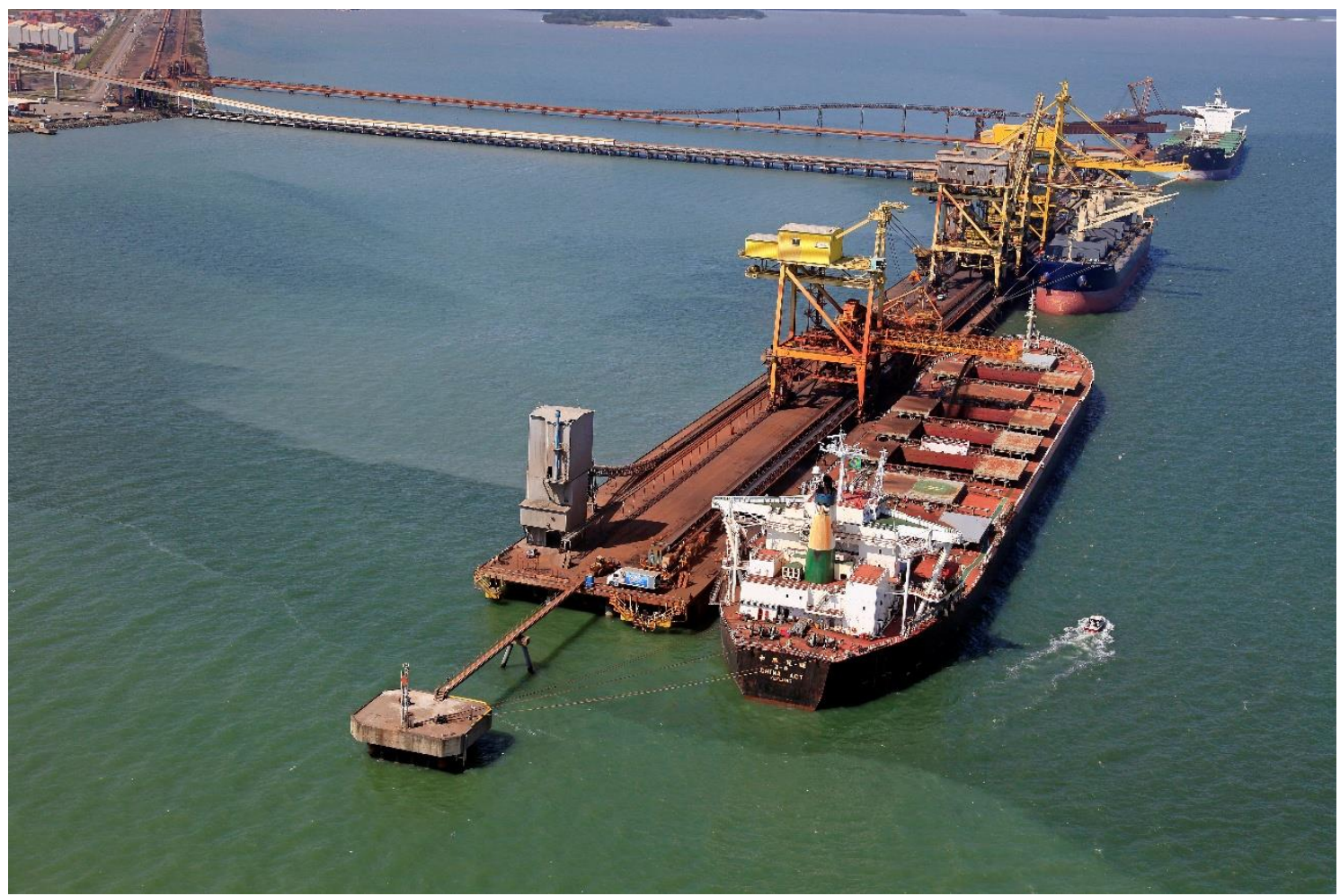

Fonte: Autor

A Figura 5 ilustra o píer da CSN onde possui 2 berços de atracação destinados as operações realizadas no TECAR. O berço 101 dedicado a operação e manuseio de carvão e o berço 102 destinado as operações de minério de ferro da companhia.

\subsubsection{Atividades operacionais do terminal tecar}

A seguir, uma breve descrição do processo de manuseio de granéis no Terminal para contextualização dos leitores. O processo de manuseio de granéis no Porto de Itaguaí contempla dois (2) grandes processos, exportação de minério de ferro e importação de carvão e outros redutores. 
Figura 6 - Terminal de Cargas TECAR

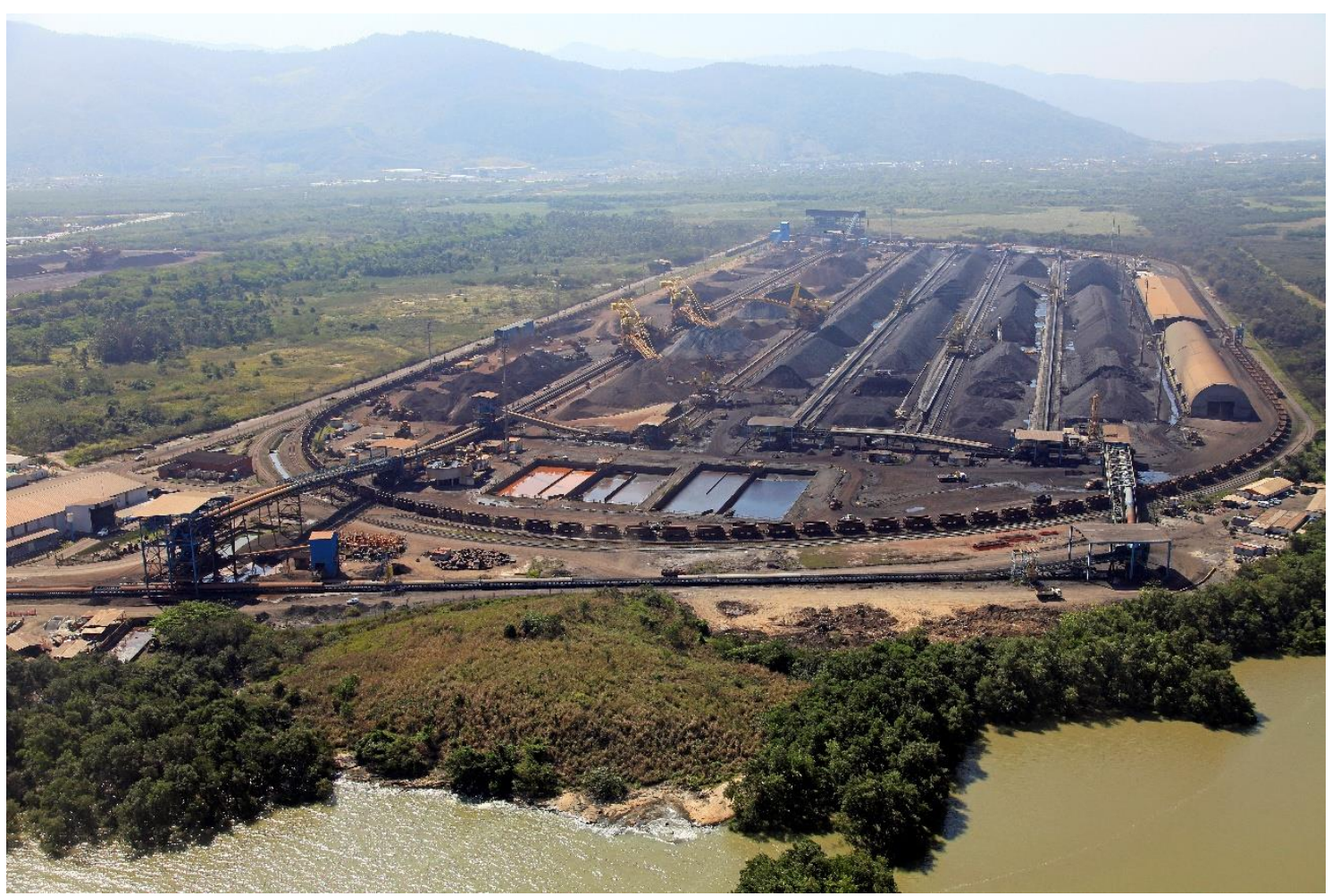

Fonte: Autor

O processo de embarque de minério de ferro começa com a descarga de trens vindos da mina em Minas Gerais através de viradores de vagões. Os viradores descarregam os trens e o minério cai em uma correia transportadora que leva este material para outro transportador para ser depositado em pátios de estocagem em forma de pilhas. Após um período no pátio de estocagem, a pilha é retomada por máquinas recuperadoras, que jogam o minério em correias transportadoras. Esses transportadores direcionam o material para ser colocado em navios que são embarcados ao exterior.

O processo de importação do carvão e redutores, foco da pesquisa em questão, iniciase com a descarga do material através dos três descarregadores de navios presentes no píer. Os descarregadores retiram o material do porão e, por meio de correias transportadoras, este material é empilhado nos pátios através dos equipamentos denominados empilhadeiras. Ao final do processo de empilhamento nos pátios de 
estocagem inicia-se o processo de recuperação do material programado. A recuperação se dá fazendo uso de um equipamento denominado recuperadora que tem por finalidade retomar a pilha levando o material, através de correias transportadoras, para a Estação de Carregamento de Vagões (ECV). A ECV tem por objetivo carregar trens com o material programado e destiná-los a Usina Presidente Vargas (UPV), onde será inserido no processo siderúrgico como matéria prima para fabricação do aço. A seguir, uma descrição minuciosa do processo do carvão e redutores para ambientação dos leitores.

Figura 7 - Descarregadores de Navios

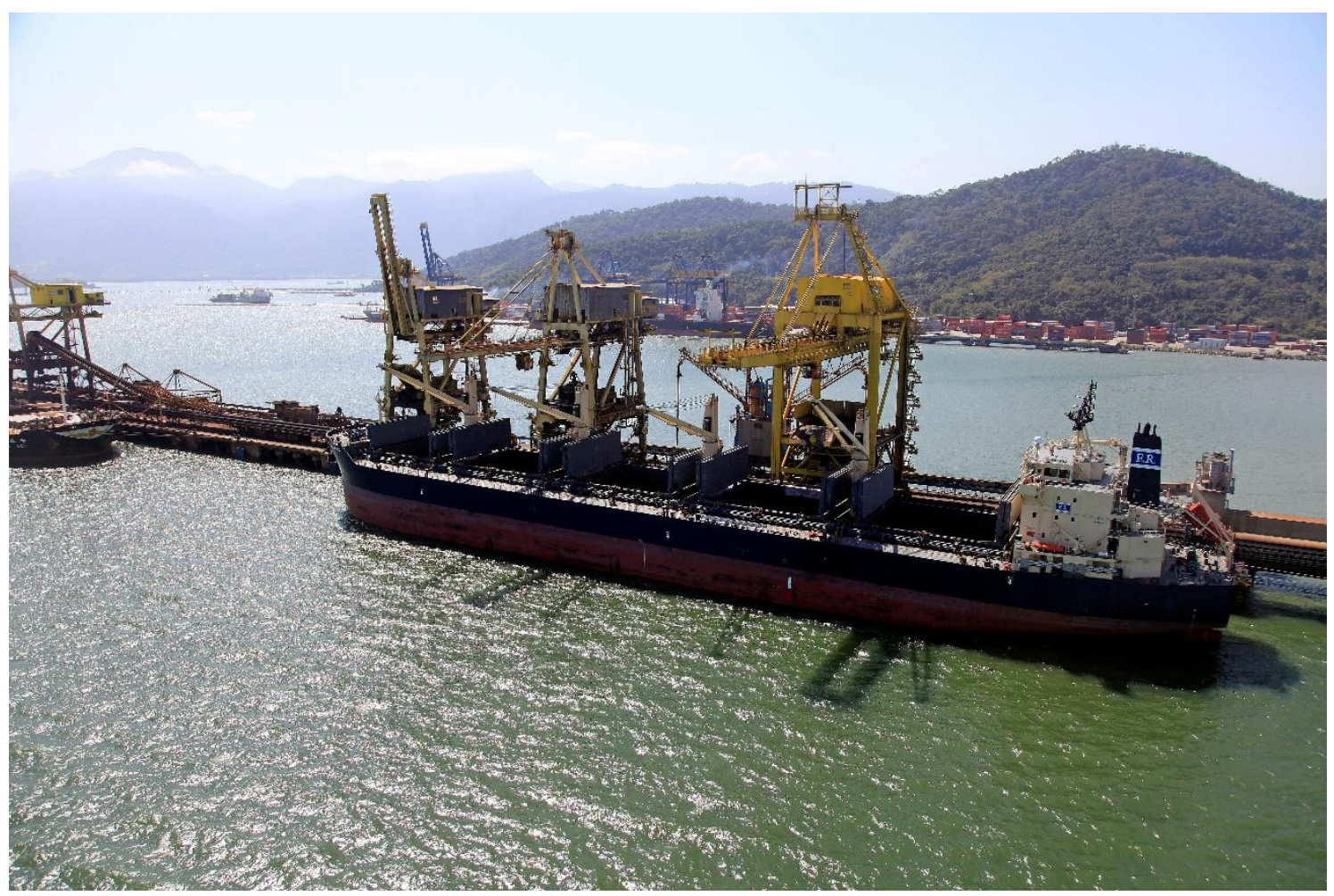

Fonte: Autor

Os Descarregadores de Navios, ilustrados na Figura 7, são equipamentos montados sobre trilhos de translação e se deslocam perpendicularmente ao navio. Possuem na extremidade de suas lanças caçambas acopladas que possuem movimentos vertical de imersão e suspensão nos porões do navio através de cabos de aço, além de movimentos perpendiculares ao navio para descarte de material nos silos dos 
descarregadores. Após recebimento do material no silo, comumente chamada de tremonha, este material passa pelos alimentadores de correia e seguem o processo caindo nas correias transportadoras para então chegarem aos pátios de estocagem através das empilhadeiras.

Figura 8 - Empilhadeira

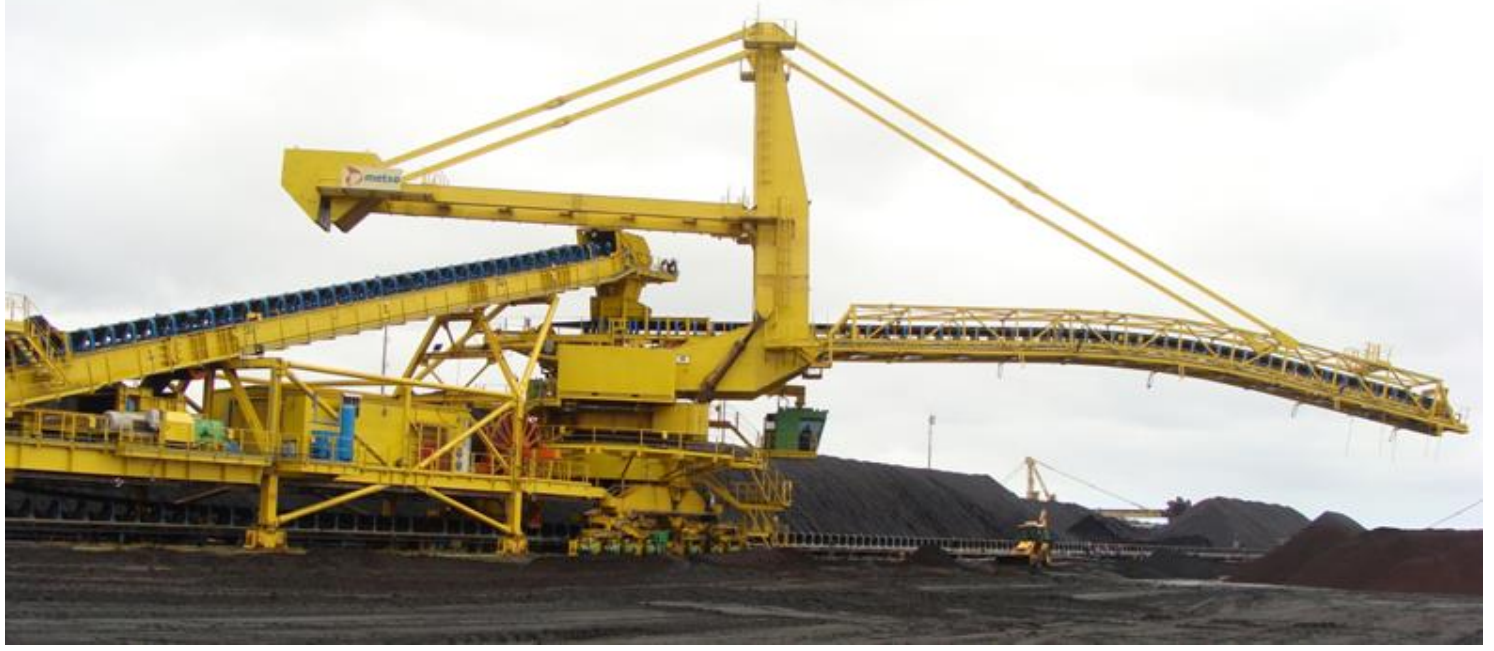

Fonte: Autor

As Empilhadeiras são montadas sobre trilhos, possuindo movimentos de translação, elevação e giro de sua lança. O material transportado no transportador de correia do pátio é direcionado ao tripper. Do tripper é descarregado, fluindo através do chute de recebimento do transportador intermediário (trailler), alimentando-o. O material é transportado pelo transportador de correia intermediário, sendo descarregado para 0 transportador da lança. Em seguida, é guiado pelo transportador da lança e projetado pela extremidade desta para formação da pilha no pátio. O processo operacional de empilhamento encerra-se neste momento, conforme Figura 8. 
Figura 9 - Pátios de Estocagem

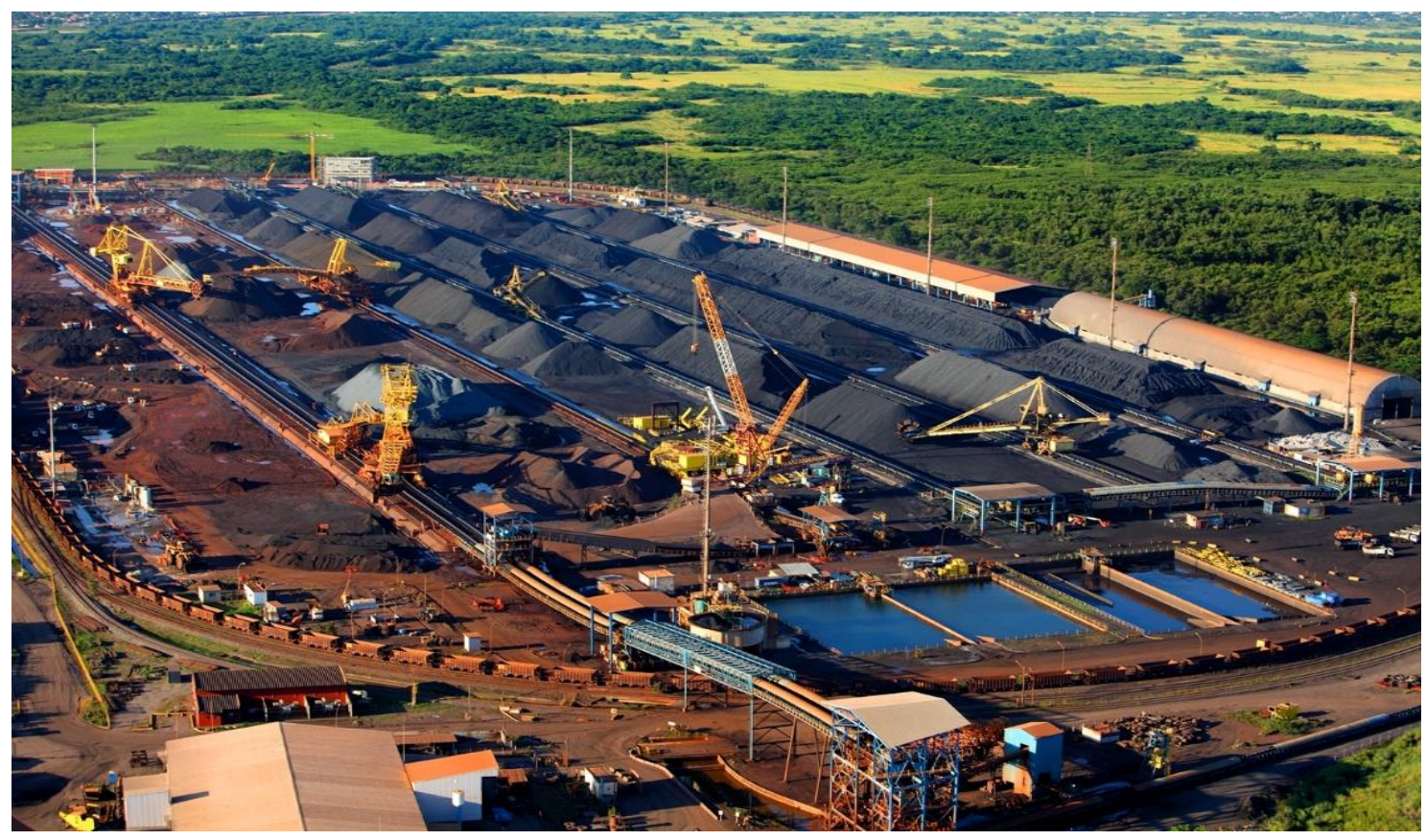

Fonte: Autor

A partir desta etapa dar-se-á início o processo operacional de recuperação. As Recuperadoras servem para recuperação do material estocado nos pátios. Operam recolhendo o material das pilhas e alimentando os transportadores de correia que o levam ao seu destino. A recuperação é realizada por meio de uma roda com caçambas instalada na extremidade da lança. A recuperadora é montada sobre trilhos, possuindo movimentos de translação, elevação e giro da lança. A máquina é controlada pelo operador instalado na cabine de operação, botoeiras locais adicionais estão instaladas próximas a cada acionamento ou grupo de acionamentos, possibilitando a execução da partida ou parada de cada mecanismo do local, individualmente ou em grupo. A recuperadora deposita o material nas correias transportadoras que direcionam para a ECV. 
Figura 10 - Recuperadora

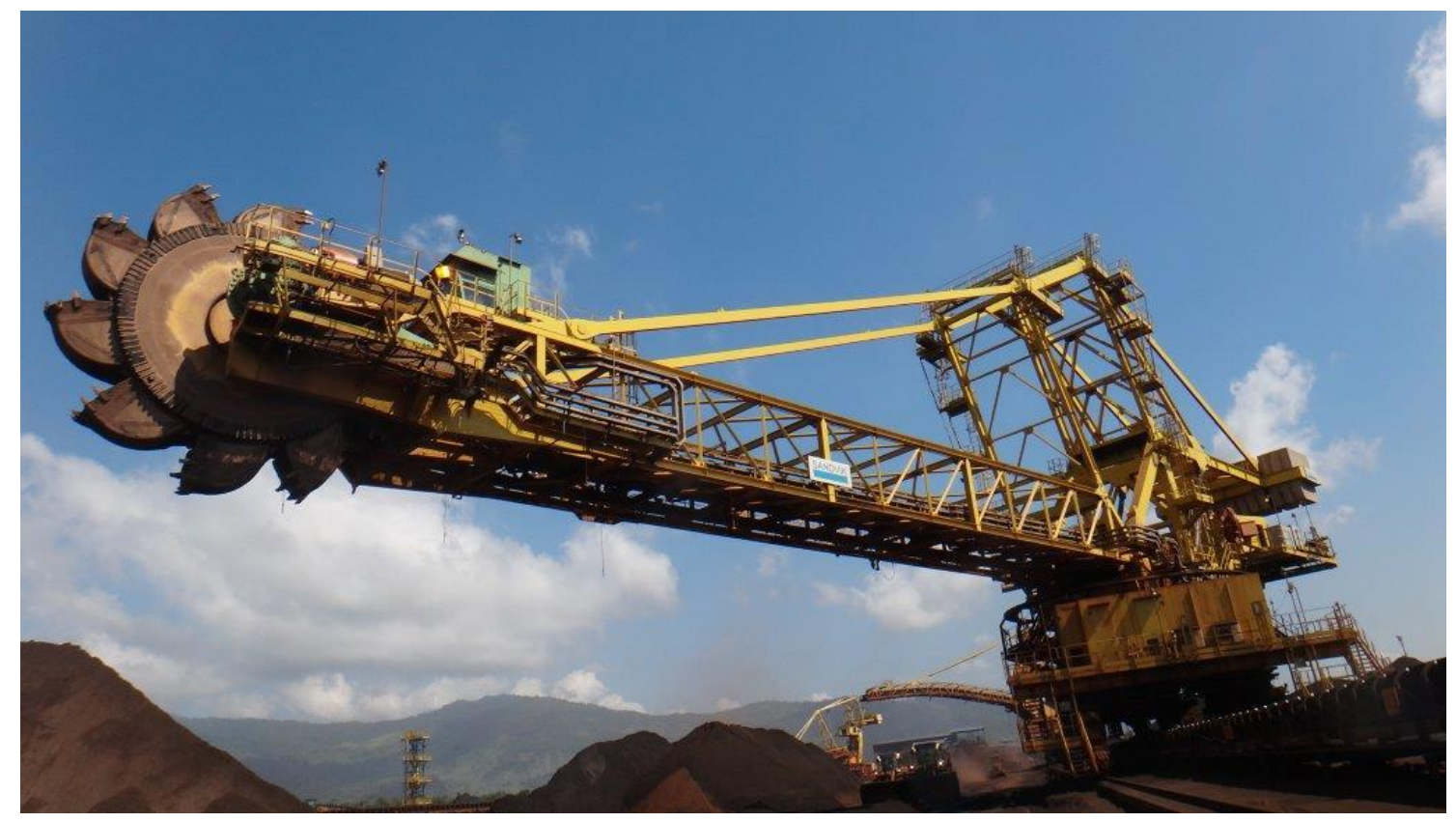

Fonte: Autor

O material chega na Estação de Carregamento de Vagões através de correia transportadora e é convertido em dois silos com auxílio de um tripper que tem por objetivo distribuir o material realizando o deslocamento para cima de cada silo. Ao final de cada silo há um alimentador que regula a vazão de material para as correias transportadoras subsequentes. Após passagem pelas correias transportadoras da ECV o material passa pelo último chute antes da queda no vagão do trem. O trem é carregado pelo operador da ECV e sai com destino para UPV, conforme mencionado anteriormente. 
Figura 11 - ECV Estação de Carregamento de Vagões

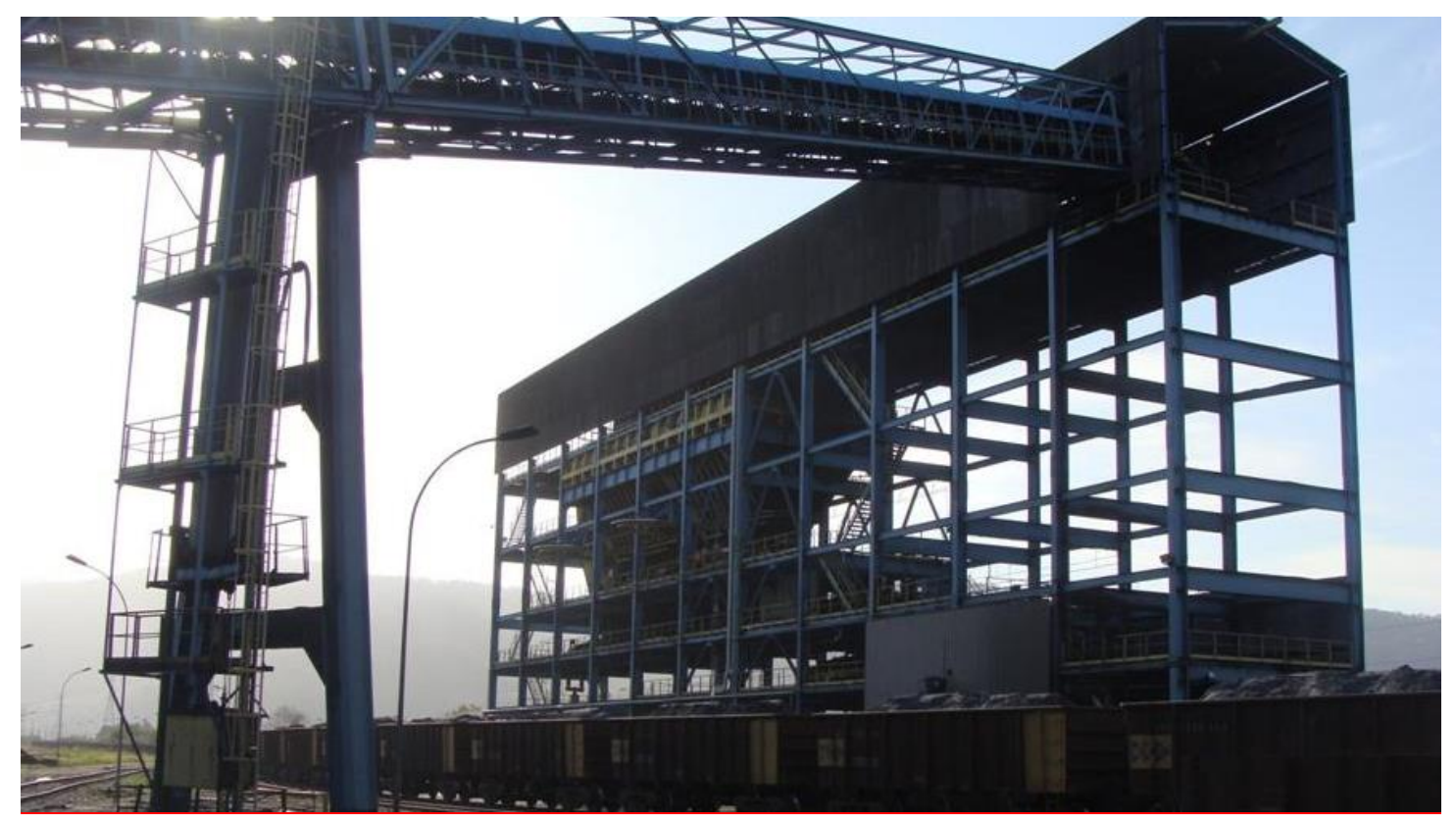

Fonte: Autor

Portando, dentro do processo de manuseio de carvão no TECAR, a partir do carregamento do trem de carvão, coque e $\mathrm{PCl}$ para abastecimento da usina, a operação da estação de carregamento de vagões - ECV é considerado a última etapa do processo dentro do terminal.

\subsection{COLETA DE DADOS}

O tipo de amostra definida, contempla os dados analisados nos anos 2014 e 2015, referente aos sistemas de importação de redutores, processo de armazenagem e despacho ferroviário para a UPV.

Foram realizadas entrevistas com a área comercial da CSN, juntamente com o cliente atendido pelo porto, neste a caso a UPV, a fim de buscar entendimento sobre procedimentos de compra com as variáveis e premissas que compreendem toda essa cadeia logística. 
Os dados utilizados para desenvolvimento da pesquisa, foram coletados através do banco de dados obtidos pelos seguintes meios:

- Systeme, Anwendung und Programme (SAP): Software específico de gestão de dados e processos;

- Planilhas em Excel: Apontamentos e controles diários do processo produtivo, de posse área de Programação e Controle da Produção - PCP do terminal;

- SCOPO: Programa com interface entre as áreas de logística operacional do porto, área comercial e programação da UPV.

\subsection{TRATAMENTO DOS DADOS}

Os dados foram levantados, a partir dos documentos dos navios, denominado Statement of Facts - SOF, que contém a linha do tempo do navio, considerando desde o momento que em que a NOR é aceita pelo terminal, até o fim da descarga do navio, onde esse documento é assinado pelo draft surveyor e pelo comandante do navio. Cada navio foi analisado individualmente, e as informações contidas nesses documentos foram inseridas em uma planilha de Excel, de forma cronológica, a fim de consolidar e facilitar as análises contidas nos dados imputados.

Figura 12 - Linha do tempo médio dos navios

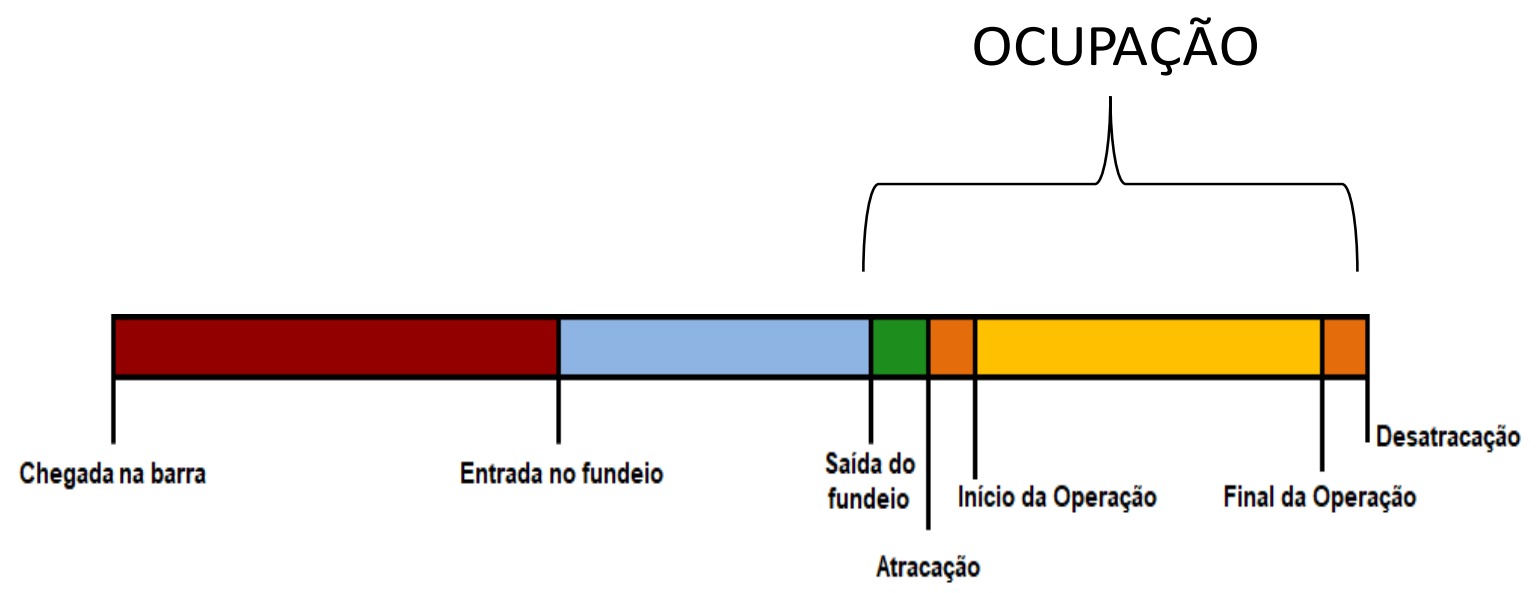

Fonte: Autor 
Para validação do modelo, é importante que se considere a ocupação média do terminal, pois este é um nível de serviço a ser calibrado corretamente no modelo de simulação.

A partir dos dados extraídos do SOF's e tabulados, foram obtidas as informações referentes à linha do tempo das embarcações, conforme demonstrado na Figura 12. Importante pontuar que o processo de remoção de outliers, padronização e tratamento foi efetuado, em grande parte, manualmente.

Os dados referentes às análises de estoque e informações referentes aos carregamentos dos trens foram levantados a partir de um controle já existente e realizado pela área de PCP do terminal através das planilhas de Excel e do sistema SAP.

A fim de investigar as atividades de encomenda de navios, foi realizado uma entrevista com a área comercial, conforme apêndice $C$ e $D$, que informou todas as etapas do processo:

- Solicitação da carga no terminal, a pedido da Usina;

- Tempo de negociação da carga;

- Tempo de negociação do frete marítimo;

- Definição da janela de atendimento no porto de origem;

- Celebração dos contratos.

Outra entrevista realizada para coleta de informações, contou com a colaboração da área operacional da UPV, que contribuiu com algumas definições de dados e parâmetros, na caracterização da integração porto usina.

\subsection{DESENVOLVIMENTO DO MODELO COMPUTACIONAL}

Para esse estudo, o modelo computacional foi implementado no AnyLogic, software esse que detém ferramentas integradas de simulação por sistemas dinâmicos, eventos discretos e baseada em agentes, tudo em uma única linguagem de modelagem. 
A interface com o usuário é bastante amigável e permite uma flexibilidade que facilita o modelador a desenvolver seus modelos de forma ordenada e distintas, conseguindo replicar situações reais em um modelo de simulação.

\subsection{VALIDAÇÃO DO MODELO}

Chwif e Medina (2015) reforçam a importância da etapa de verificação e validação de um modelo de simulação, por se tratar da averiguação da competência do modelo computacional em imitar virtualmente um cenário real. De acordo com Chwif e Medina (2015) "[...] o modelo computacional implementado deve ser comparado com o modelo conceitual, com a finalidade de avaliar se a sua operação atende ao que foi estabelecido na etapa de concepção. Para a validação computacional, alguns resultados devem ser gerados, observando se o modelo é uma representação precisa da realidade".

Para validação do modelo, será necessário a comparação dos dados reais analisados, em detrimento dos valores gerados do modelo computacional. Será necessário gerar um log de validação dos navios de forma determinística, utilizando o mesmo perfil de chegadas reais dos navios no terminal.

Os dados que servirão de validação para o modelo computacional com os dados reais, serão a taxa de ocupação do berço e o número médio de dias em fila dos navios no terminal.

\subsection{DEFINIÇÃO DOS CENÁRIOS}

Os cenários foram definidos de acordo com a atual conjuntura dos negócios da companhia. Em detrimento de um alto custo advindo das enormes filas de navios no terminal da CSN, na operação de descarga de redutores para abastecimento da UPV. Durante a entrevista com as áreas de negócios da companhia, identificou-se que a programação de encomenda de navios, muitas das vezes, não considera o sistema integrado entre o porto e usina, bem como as filas de navios existentes no terminal e a capacidade de armazenagem do porto. Diante desse entendimento, foram definidos 2 cenários a serem considerados: 
- Chegada de navios de forma exponencial: nesse sistema com a chegada exponencial é calculado, conforme distribuição das cargas, o número de navios a cada período de 6 meses necessários para atender a demanda da usina. Os intervalos entre chegadas dos navios seguem uma distribuição exponencial, e permitem um balanço de massa completo a cada 6 meses, sem perder a estocasticidade do sistema. Nesse cenário, busca-se identificar os gargalos operacionais em detrimento do consumo diário da usina, bem como se a capacidade de estoque atende parâmetros razoáveis de atendimento aos navios.

- Chegada de navios considerando o lead time dos produtos: nesse cenário pretende-se verificar a melhor forma de encomenda dos navios, considerando a distribuição de probabilidade dos leads times dos produtos e, se o estoque de segurança de 30 dias por produtos, praticados hoje na usina, é a configuração ideal para operação do sistema integrado, sem comprometer a operação de produção de aço na usina. Importante reforçar que apesar da substituição da taxa exponencial de chegada dos navios pela probabilidade dos diferentes lead times dos produtos, o modelo mantém sua estocasticidade pois, os navios continuam chegando de forma exponencial. 


\section{DESENVOLVIMENTO DO MODELO COMPUTACIONÁL}

Neste capítulo será incialmente apresentado as etapas de implementação do sistema de simulação de eventos discretos, bem como os subsistemas da cadeia integrada do sistema porto usina. O desenvolvimento do modelo computacional trará clareza no entendimento do problema, descrito no capítulo 1, e proporcionará a busca de alternativas e possíveis soluções.

\subsection{MODELO CONCEITUAL}

Nesta etapa, é estabelecida que a fase de concepção deve abordar o levantamento de informações necessárias para definição dos objetivos e o sistema que será simulado. Isso deve culminar na modelagem conceitual do problema e na obtenção dos dados de entrada.

Botter (2001) reforça que o modelo conceitual tem por objetivo expressar as principais características de um sistema que será modelado dentro de alguma linguagem computacional. É nesta fase que são elaboradas todas as hipóteses, bem como as interações entre os subsistemas.

Chwif e Medina (2015), definem o modelo conceitual sendo o modelo de simulação expresso em alguma técnica de representação de modelos. A

Figura 13, de Chwif (1999), apresenta os passos necessários para que o estudo de simulação seja bem-sucedido. 
Figura 13 - Metodologia de simulação

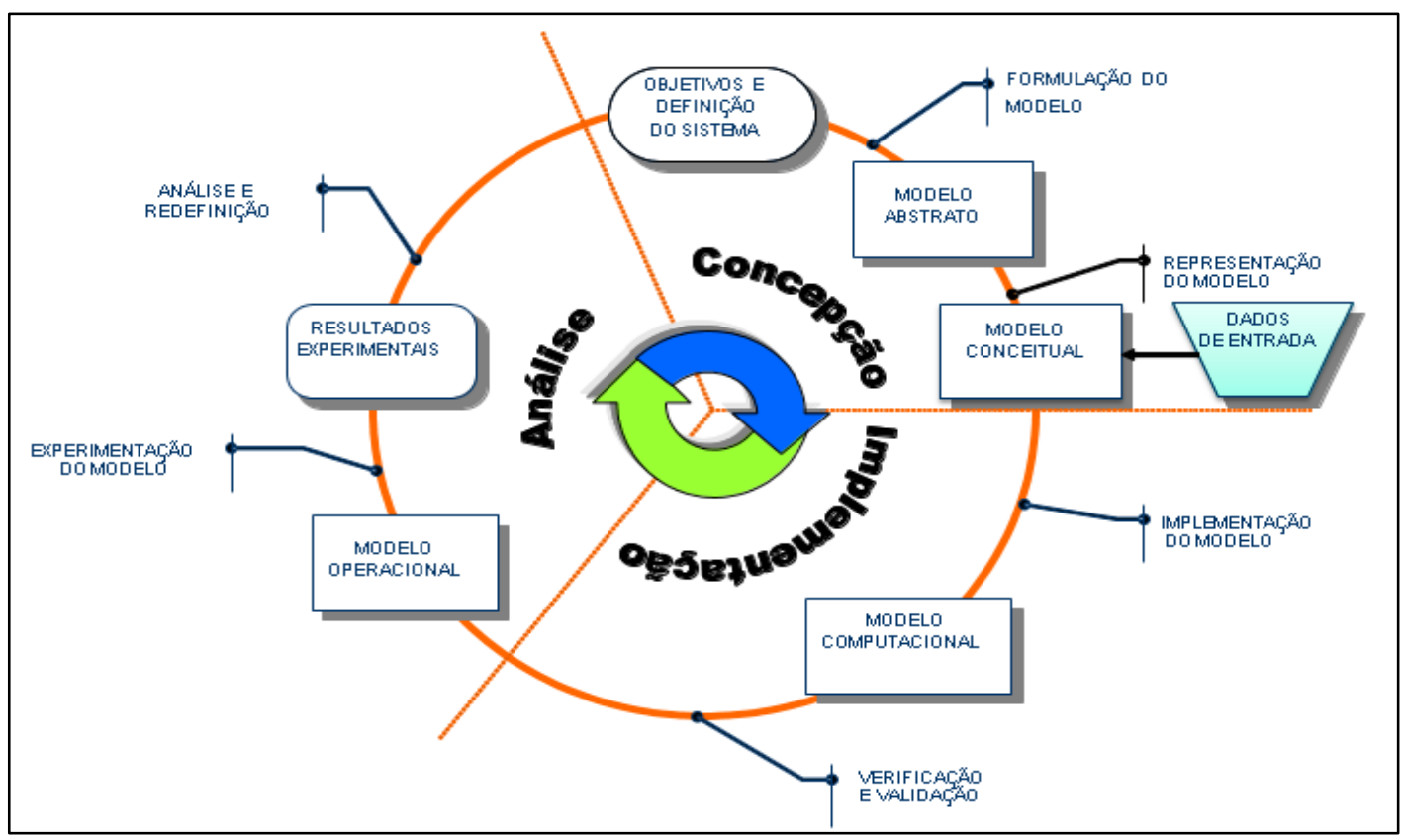

Fonte: CHWIF (1999)

Dessa forma, o projeto de simulação a ser desenvolvido e apresentado nesta pesquisa deve abordar todas estas fases, iniciando-se pela definição dos subsistemas que compõem todo o sistema a ser desenvolvido, a análise de dados, a modelagem conceitual, a implementação do modelo computacional, finalizando pela simulação e análise dos cenários estipulados na etapa de definição dos cenários.

A seguir será apresentado o sistema portuário, foco desta pesquisa, e a interação com o sistema de abastecimento da usina siderúrgica.

\subsection{SISTEMA PORTUÁRIO}

Alfredini (apud JULIÁ, 2010, p.65) considera que "um porto é uma área, abrigada das ondas e correntes, localizadas à beira de um oceano, mar, lago ou rio, destinada à atracação de barcos e navios, com toda estrutura necessária para efetuar 0 carregamento e descarregamento de cargas e pessoas, bem como instalações para movimentação de pessoas e cargas ao redor do setor portuário". 
Pode ser complementado que um sistema portuário é um ponto integrador das cadeias logísticas globais e regionais, que produzem atividades relacionada a importação e exportação, transportando: cargas; pessoas; animais; matérias-primas, entre outras.

Usualmente, estudos relacionados a problemas de capacidade portuária limitam-se a fronteira do estudo, ao processo de chegada de navios e à taxa de utilização do berço. Contudo, o desempenho do berço é o resultado da integração de todos os subsistemas portuários, desde o processo de chegada por terra até o processo de formação de fila de navios na barra.

Basicamente o sistema portuário compreende em uma representação de subsistemas, apresentado na Figura 14.

Figura 14 - Representação do Sistema Portuário

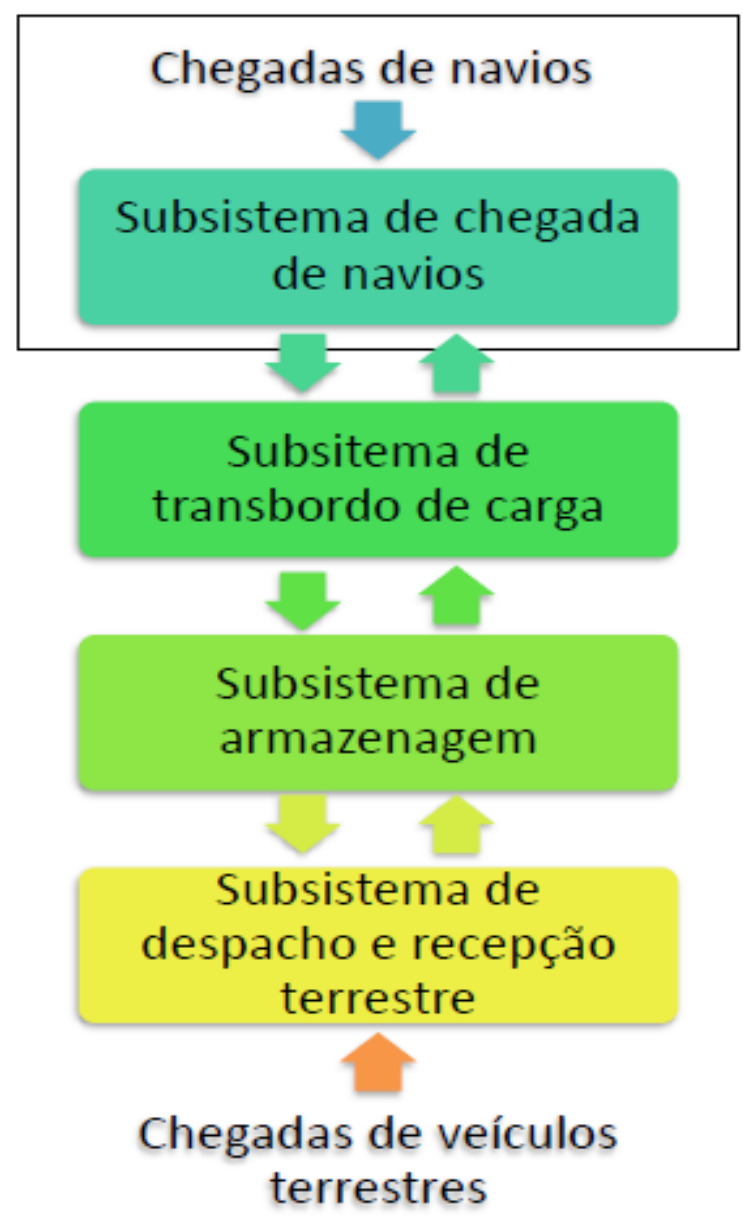

Fonte: Botter (2012) 
Para o caso em questão foi incorporado os elementos que conectam o porto com a usina em função das características do sistema que está sendo estudado, que caracterizasse por sistema integrado. Na Figura 15 foi realizada uma indicação dos subsistemas que representam apenas o sistema portuário, integrando o porto com a usina.

Figura 15 - Cadeia Logística integrada porto e usina CSN

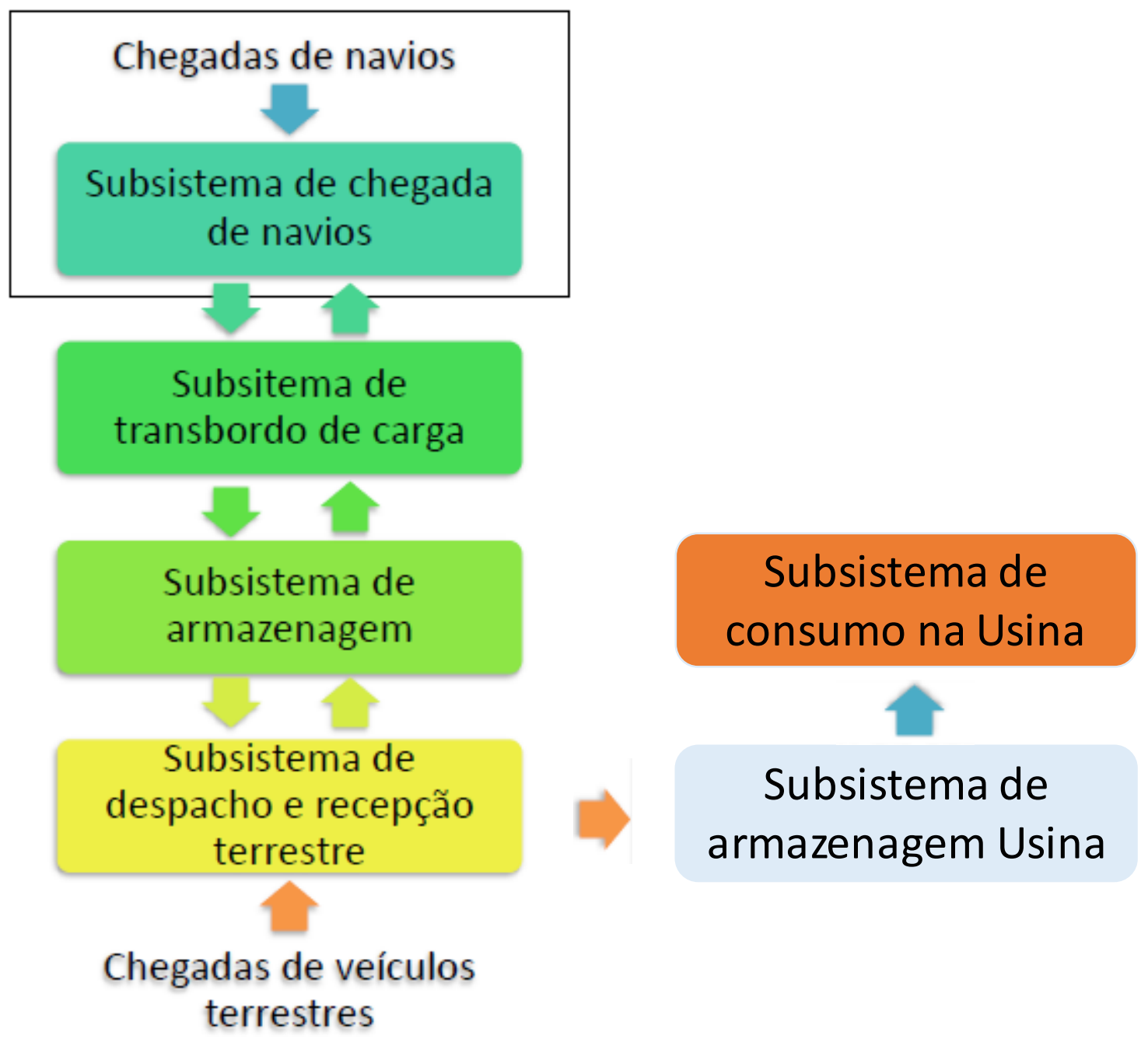

Fonte: Autor

Além do sistema portuário representado na Figura 15, o modelo conceitual pode ser composto por subsistemas compostos por meio de fluxogramas. As Figuras: Figura 
16; Figura 17; Figura 18; Figura 19; Figura 20 e Figura 21, representam todos os fluxogramas dos subsistemas da cadeia logística porto e usina.

\subsubsection{Subsistema chegada de navios}

Conforme apresentado na Figura 15, o fluxograma refere-se à chegada de navios no terminal, condicionados de forma aleatória e através de uma demanda de matéria prima solicitada pela usina. Em geral, a partir do momento que os navios são gerados, eles ficam aguardando em fila, respeitando o processo de atendimento do tipo primeiro que entra, primeiro que sai, mais conhecido como a regra first in, first out "FIFO". A análise para verificação de liberação do navio em fila, respeita os seguintes parâmetros:

- O navio chega e vai para uma de 3 filas, dividida por tipo de carga onde é impedido de continuar se a cobertura do produto que carrega, já em estoque no sistema, for maior que o parâmetro dias;

- A fila tem um recurso de controle que permite apenas um navio de cada tipo disputar o berço, dessa forma os navios não furam a fila de outros que tenham o mesmo produto;

- Os navios que passaram pelo bloqueio e estão aguardando o berço são ordenados em prioridade conforme o nível de cobertura do estoque de seus produtos no sistema;

- O berço é alocado apenas quando existe espaço (corrigido por um fator, no input) para descarga;

- As manobras de atracação, pré e pós operação, desatracação, carga e taxa de descarga dos navios seguem distribuições imputadas nas funções do modelo;

- Disponibilidade do berço de atracação: caso tenha um navio já em operação, o navio posterior a ele, deverá aguardar todo descarregamento do navio, mais o tempo de pós-operação do navio em descarga;

- Verificação de disponibilidade de área no pátio de estocagem: caso a carga transportada pelo navio seja maior que o espaço disponível em estoque, o mesmo deverá aguardar em fila, até que seja liberado área no pátio; 
No caso de atendimento às regras de verificação, aloca-se o canal para manobra de atracação do navio, e posteriormente aloca-se o berço do sistema de descarga. Após a realização da manobra de atracação o navio está apto a descarregar.

Apenas quando o navio inicia a navegação para o berço de atracação o seu tempo de espera em fila para de ser computado.

A Figura 16, representa o fluxograma do subsistema de chegadas de navios no terminal e as lógicas para atracação.

Figura 16 - Fluxograma do subsistema de chegada de navios

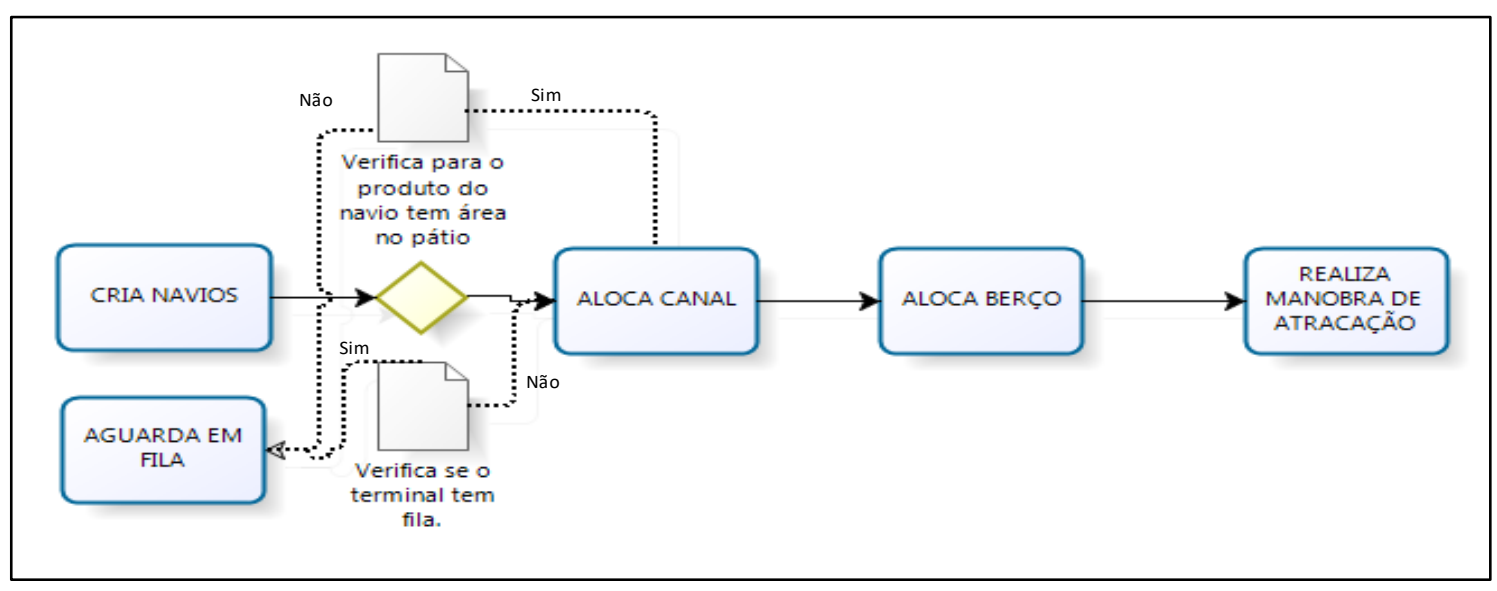

Fonte: Autor

\subsubsection{Subsistema transferência navio terminal}

Após todos os requisitos de verificação de atracação dos navios estarem atendidas, e o berço devidamente ocupado, inicia-se o processo de pré-operação, que consiste no tempo de preparação do terminal para início da operação de descarga. Esse processo leva em consideração as seguintes atividades:

- Amarração dos cabos de Través, Spring e Lançantes no berço;

- Lançamento das escadas de acesso ao navio;

- Tempo de arqueação inicial do navio, que consiste na verificação exata do volume de carga a bordo, realizado pela equipe de inspetoria do terminal. 
Em seguida dá-se o início ao processo de descarga, seguido por um plano de descarregamento por porões. Em virtude das características do navio que está alocado no berço, a taxa de descarga em função de sua carga é ajustada. O processo final de operação, pós-operação, consiste no término de descarga do navio que, logo após essa atividade, aguarda no berço para realização do procedimento de verificação, inspeção e arqueação final, bem como a entrega de documentação, para posterior manobra de desatracação.

Figura 17 - Fluxograma do subsistema de transferência navio terminal

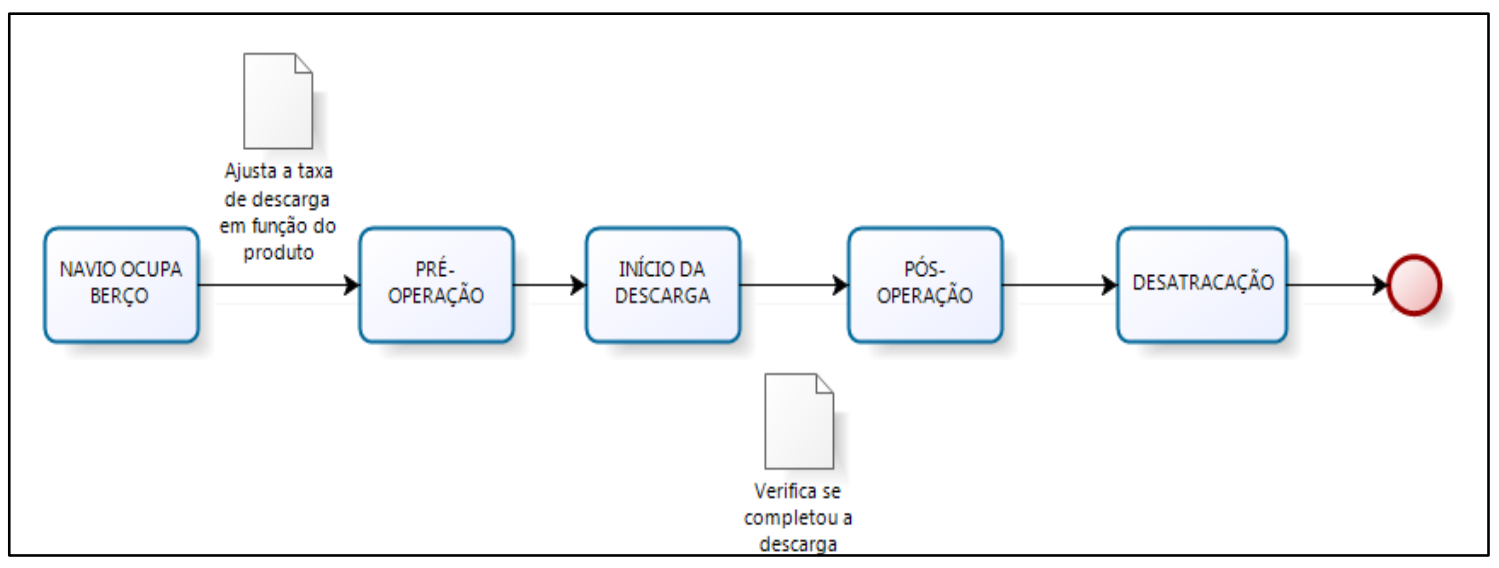

Fonte: Autor

\subsubsection{Subsistema armazenagem}

A área de estocagem do terminal é composta por 3 pátios de armazenagem de material. O processo de transferência da carga do navio aos pátios de armazenagem, incide na escolha do equipamento de empilhamento e no pátio de destino do material.

Os pátios de estocagem têm uma restrição de volume; o que ocorre em muitas das vezes, é o navio ficar aguardando na barra a liberação de área, conforme visto no subsistema de chegada de navios. O procedimento de empilhamento do terminal, é 
do tipo Chevron ${ }^{1}$, regra essa que facilita na posterior retomada do material para abastecimento dos trens.

Figura 18 - Fluxograma do subsistema de armazenagem

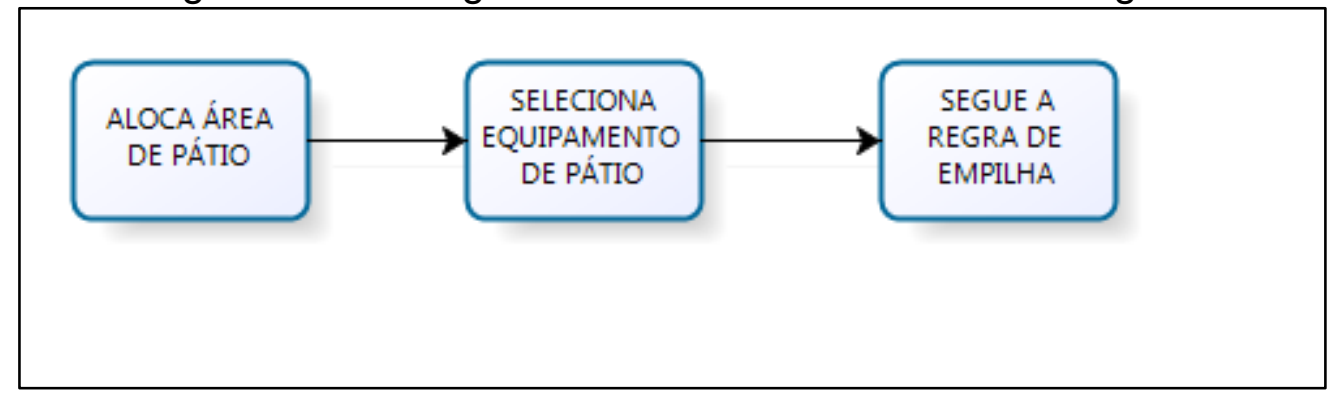

Fonte: Autor

\subsubsection{Subsistema transferência terrestre}

O sistema de recarga de trens no terminal é adotado pelo fator de verificação da fila e, caso o recurso esteja disponível, é alocado o trem, conforme a disponibilidade de produtos nos pátios.

Em seguida, é realizada a operação de manobra do trem dentro da pera ferroviária do terminal, e ajustada a taxa de recarga de acordo com o tipo de material a ser transportado para a usina. Logo após o término de carregamento do trem, o mesmo realiza o processo de retorno a usina.

\footnotetext{
${ }^{1}$ No método Chevron de empilhamento, o material é depositado pela empilhadeira em movimentos da esquerda para direita, sobre a linha central da pilha. É um método utilizado para garantir uma boa homogeneização de toda a formação da pilha no pátio de armazenagem.
} 
Figura 19 - Fluxograma do subsistema de transferência terrestre

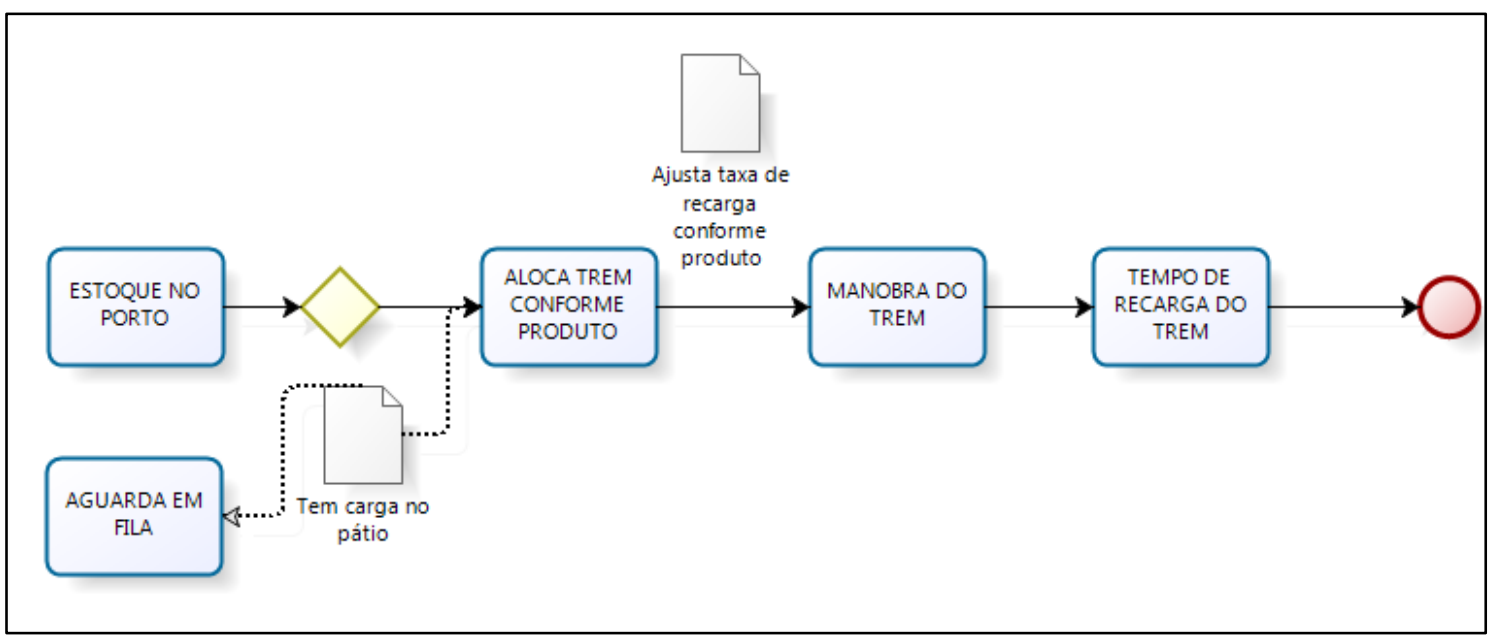

Fonte: Autor

Os trens chegam ao terminal de modo a garantir o balanço de massa entre a carga a ser descarregada no porto e a carga a ser carregada na estação de carregamento de vagões, que será transportada para Usina. Um parâmetro configurável no modelo, determina a antecedência mínima de chegada de trens, ou seja, o número de dias entre a chegada do navio, a verificação dos estoques no porto e estoque Usinas e determina qual carga deverá ser carregada no terminal para que não falte insumos para a produção nas Usinas.

\subsubsection{Subsistema transporte porto usina}

A operação de transporte de trens entre o porto e a usina é realizada através de um ciclo fechado, onde existe um número de tabelas para atendimento à demanda de produção de aço na usina. Esse sistema segue uma distribuição de demanda, levando para usina o produto com menor cobertura de estoque. Todo o ciclo do trem compreende nas seguintes etapas:

- O trem vazio aguarda em fila no terminal;

- Tempo de recarga do trem no porto;

- Transit time carregado até a usina;

- Aguarda em fila na usina; 
- Tempo de descarga do trem na usina;

- Transit time vazio até o porto;

Figura 20 - Fluxograma do subsistema do transporte porto usina

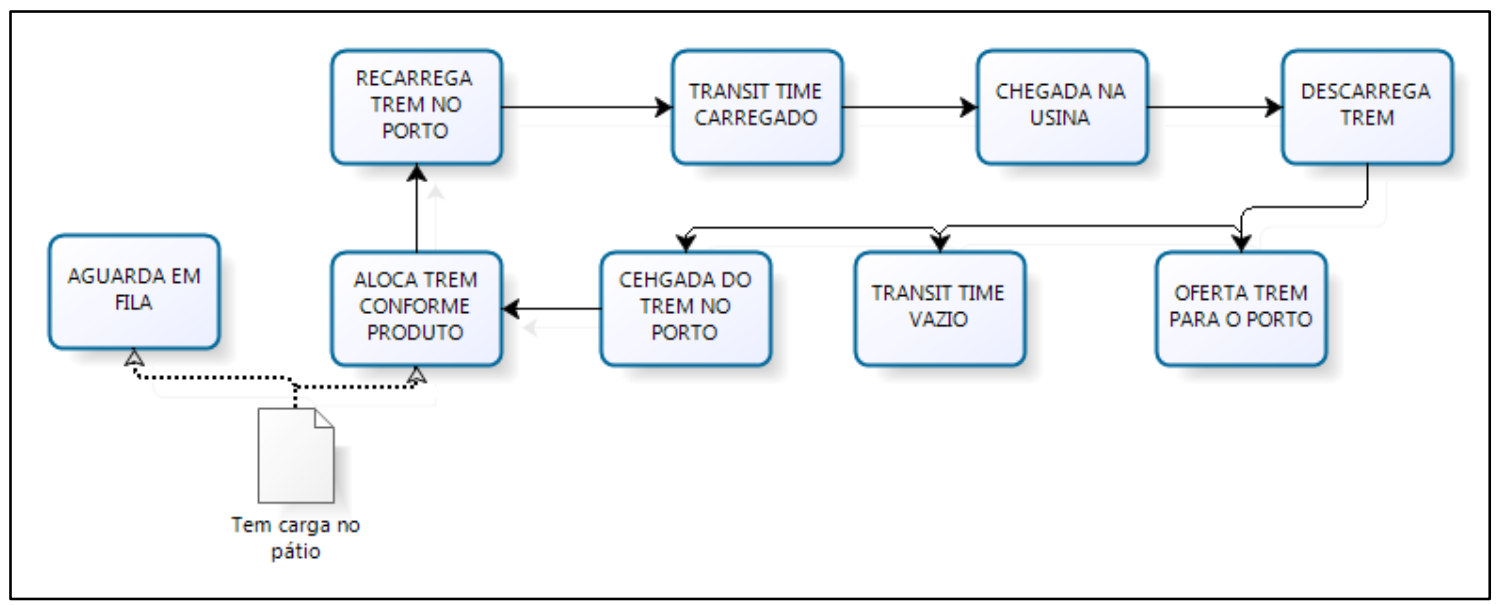

Fonte: Autor

\subsubsection{Subsistema pátio usina}

Através de uma composição de matérias-primas para fabricação do aço, a usina verifica os produtos em seu estoque a ser consumida diariamente. Essa taxa é ajustada de acordo com o plano de consumo dos produtos em estoque na usina. Após verificação da disposição dos produtos no estoque da usina, é descontado esse material do estoque.

Figura 21 - Fluxograma do subsistema pátio usina

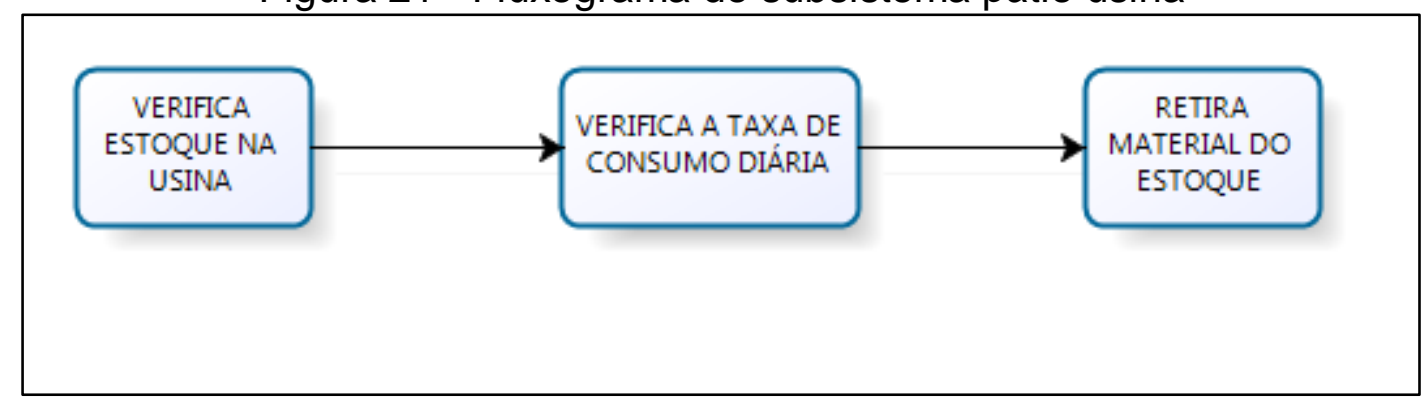

Fonte: Autor 


\subsection{IMPLEMENTAÇÃO COMPUTACIONAL}

Nesta etapa, Chwif e Medina (2015) descrevem que: "A modelagem computacional nada mais é do que a tradução do modelo conceitual em alguma linguagem de simulação".

A Figura 22, demonstra a plataforma de criação do modelo computacional desenvolvido, denominado de Port Discharge, utilizando o software AnyLogic.

Figura 22 - Plataforma do modelo computacional Port Discharge

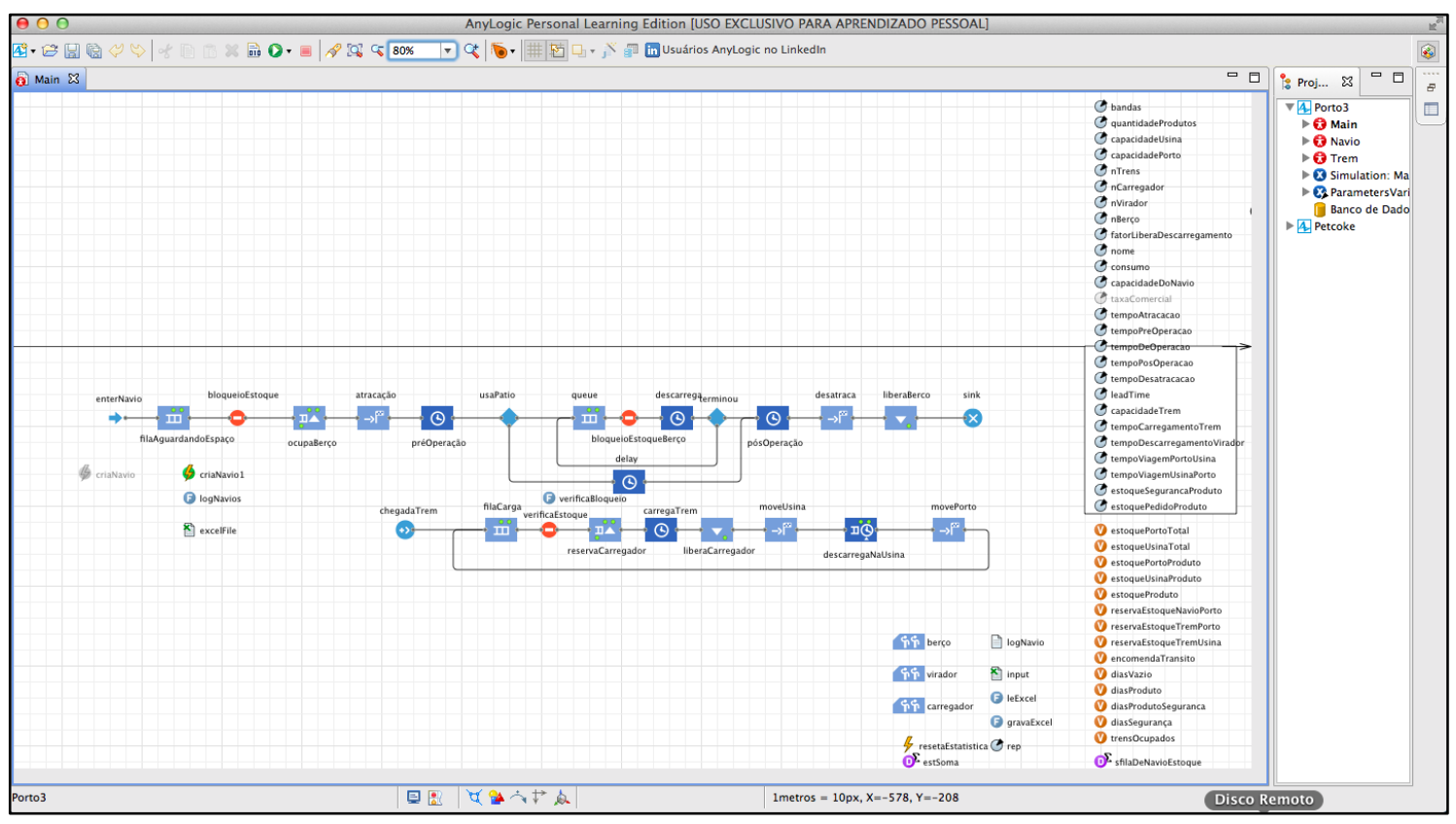

Fonte: Autor

O modelo interage em função das variáveis definidas no sistema e dos parâmetros de operação definidos nos subsistemas. A Figura 23, demonstra todo o time line do navio no sistema de operação de descarga de redutores no terminal, considerando o momento da criação do navio até a etapa de liberação do navio no sistema. 
Figura 23 - llustração do modelo computacional do subsistema de chegada de navios

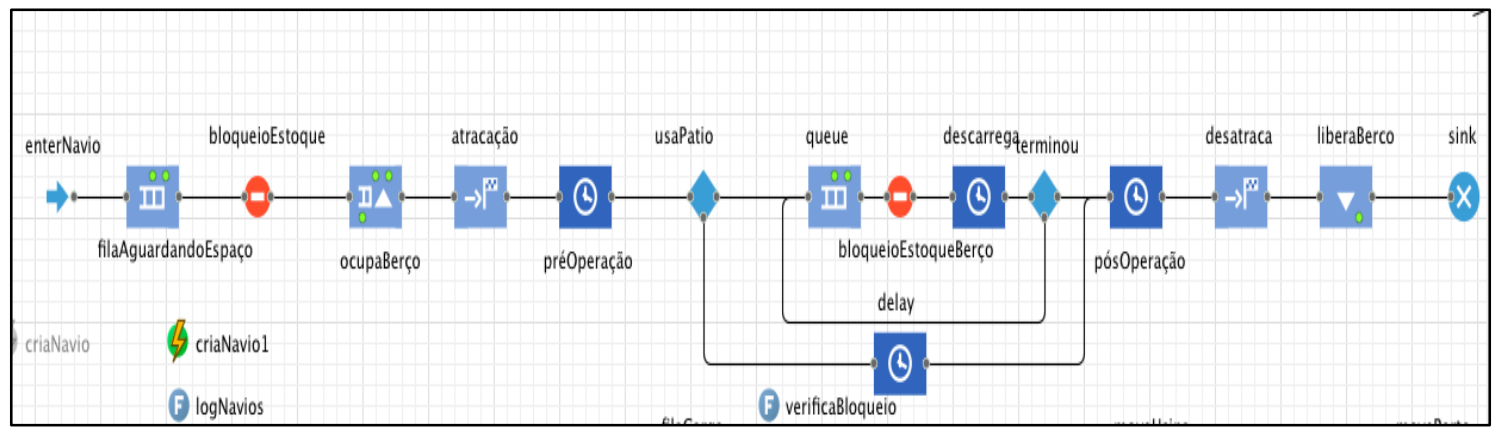

Fonte: Autor

Durante a etapa da vida do navio no sistema, existe toda a interação dos subsistemas de armazenagem no porto, carregamento e expedição dos trens para usina, juntamente com a armazenagem e consumo diário das matérias-primas na usina, representado na Figura 24.

Figura 24 - Sistema de armazenagem e despache terrestre

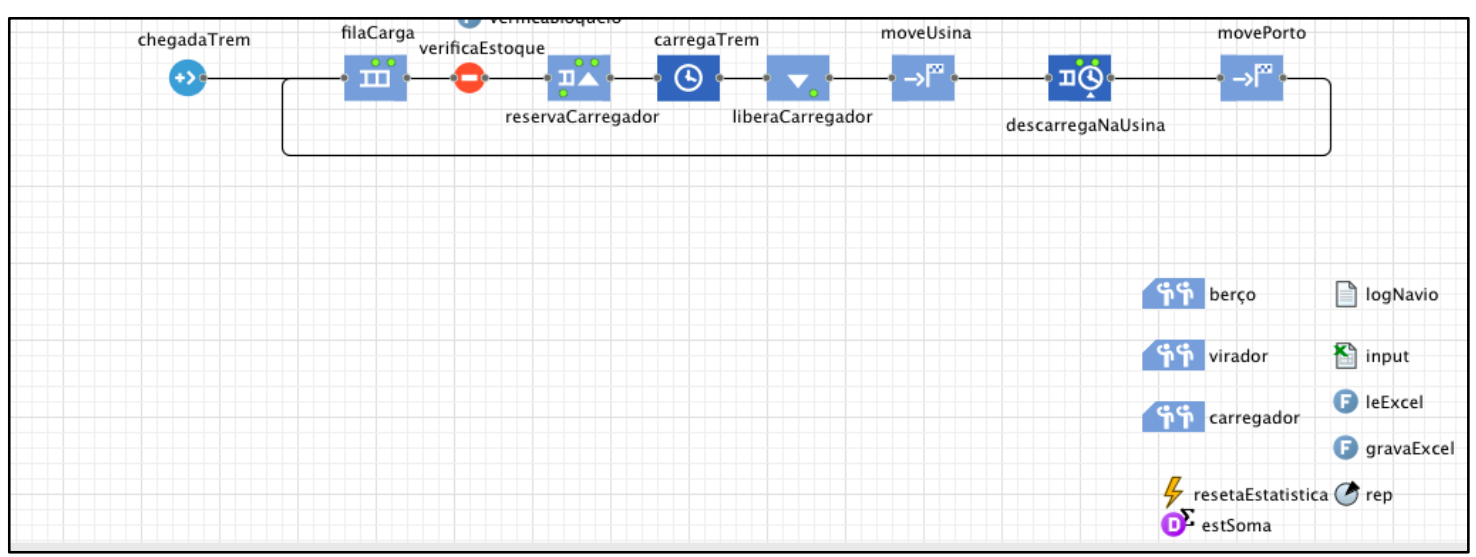

Fonte: Autor

O modelo também contempla um módulo de animação que ilustra a operação no terminal de forma instantânea o comportamento de todo sistema simulado. Além da visualização operacional do sistema, existe também a visualização gráfica dos parâmetros pré-selecionados, que indicam o desempenho dos indicadores, demonstrado na Figura 25. 
Figura 25 - Animação do modelo computacional

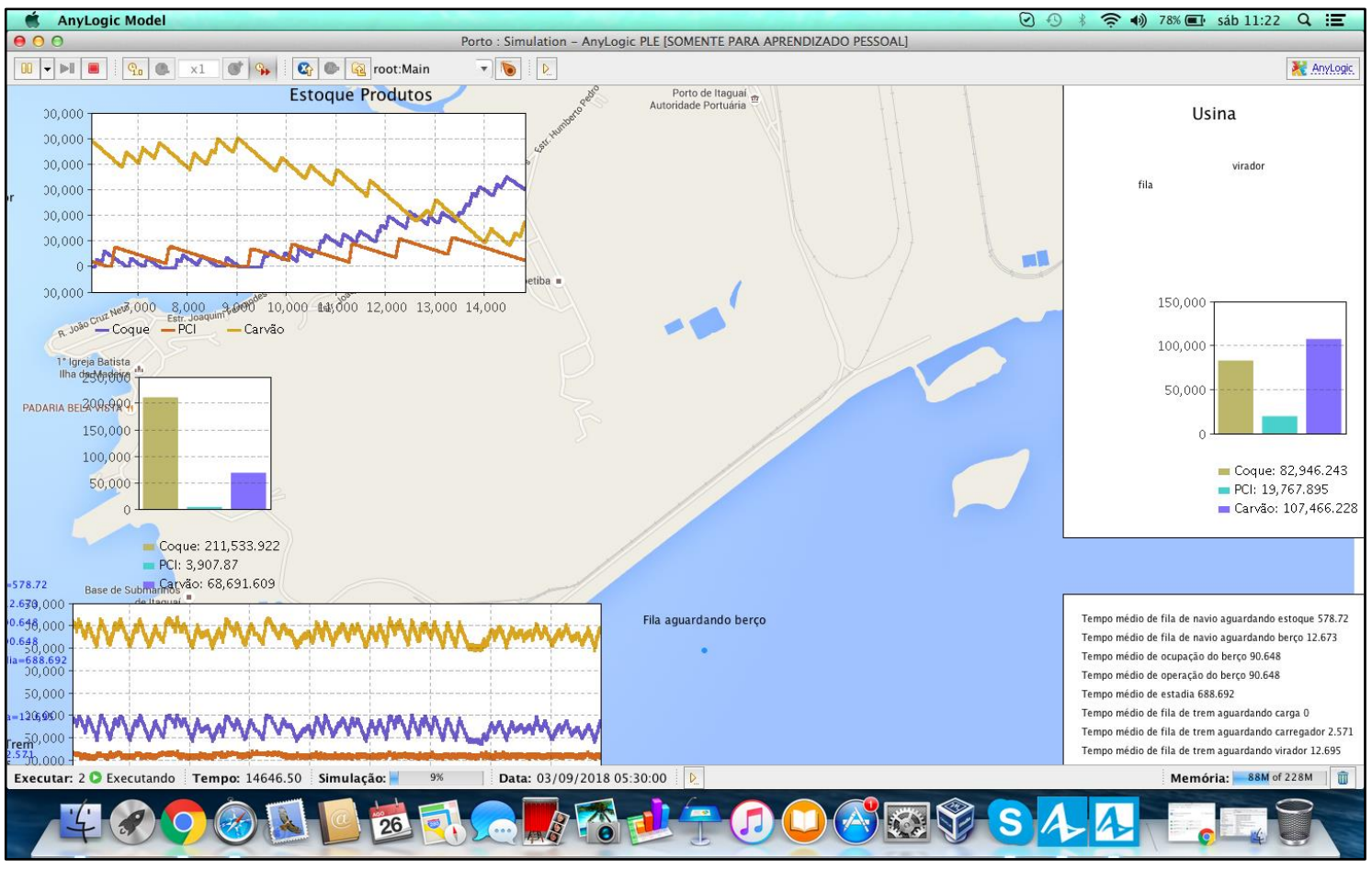

Fonte: Autor

Brito (2011) explica que os modelos SED são usualmente altamente demandantes em dados precisos, o que pode tornar o processo de entrada de dados bastante extenso, difícil e tedioso.

Por outro lado, a ferramenta de modelagem SED é também capaz de oferecer uma excelente visão do sistema modelado através de animação gráfica, tornando as operações e processos diretamente observáveis, aumentando assim a sensibilidade do usuário ao modelo ao revelar visualmente processos como a formação de filas e outros gargalos operacionais do sistema. (BRITO, 2011)

Após a simulação computacional do sistema Port Discharge, o modelo faz interação com a planilha de Excel, carregando os resultados dos dados simulados, de acordo com os indicadores-chaves previamente definidos, representados na Figura 26. 
Figura 26 - Output dos resultados do modelo computacional

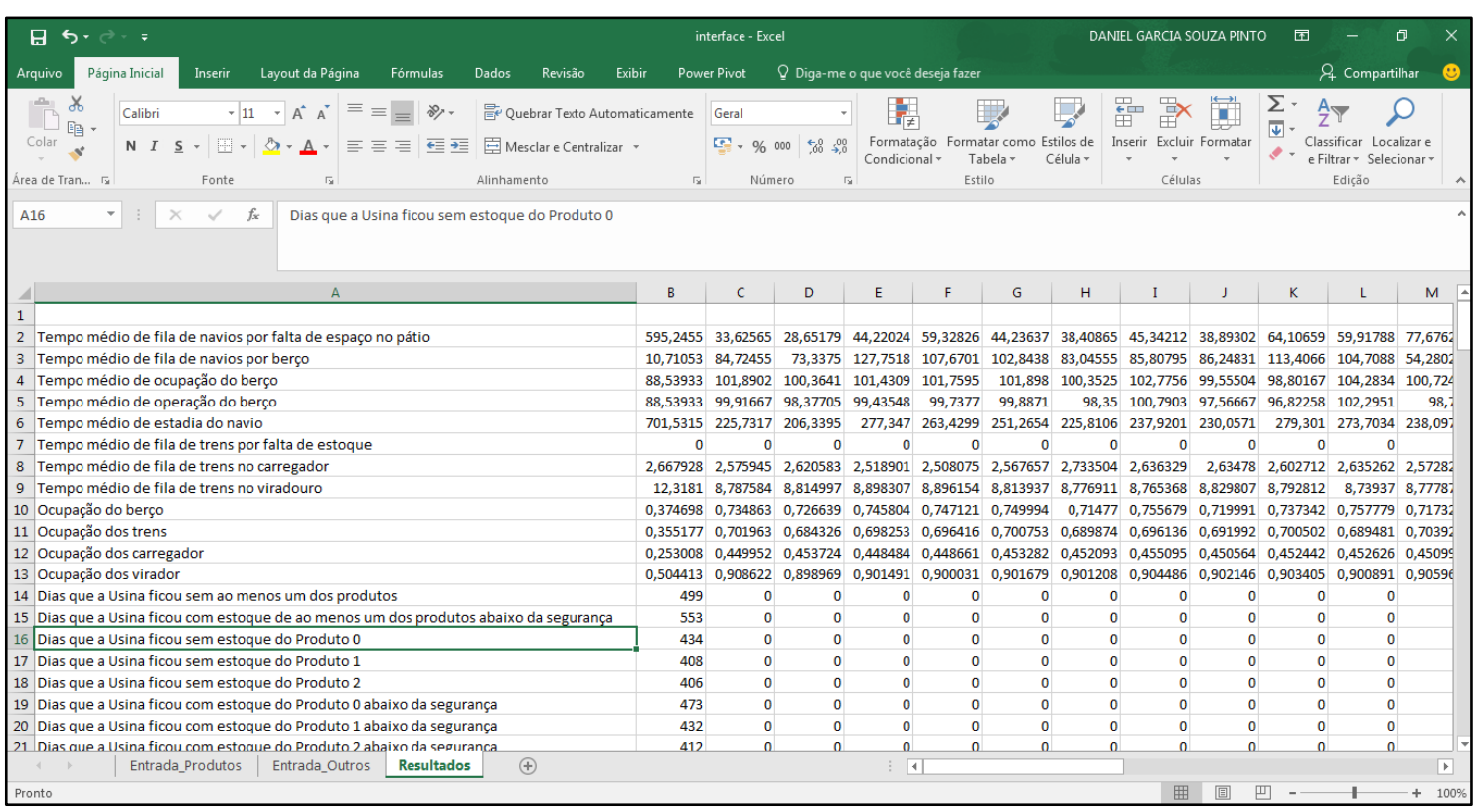

Fonte: Autor

A partir dos resultados demonstrados na planilha, é possível realizar as análises simuladas e posterior ajustes no modelo, caso necessário. Importante é a sensibilidade e a experiência de quem está avaliando, para que qualquer inconformidade seja identificada. 


\section{RESULTADOS}

Neste capítulo são apresentados os dados que caracterizam o sistema real, e servem para definir os cenários de análise. Também serão apresentados os resultados relativos ao cenário base, o qual será usado na validação do modelo, e que permitem um entendimento do sistema real. Também são realizadas análises de sensibilidade do modelo, a fim de gerar soluções e propor alterações que possam reduzir a fila de navio no terminal e, consequentemente, aumentar o nível de serviço como um todo.

Outro ponto relevante do estudo foi a contribuição dos stakeholders inseridos no cenário operacional e estratégico da companhia, que através das entrevistas realizadas e anexadas aos apêndices desse trabalho, trouxeram maiores detalhes dos problemas inseridos em todo sistema e levantaram algumas possibilidades também na melhoria do processo.

\subsection{ANÁLISE DE DADOS}

Como visto anteriormente no capítulo 4 , a análise de dados é primordial para o desenvolvimento de um projeto de simulação. Sendo assim, foram extraídos os dados definidos para o modelo nos anos de 2014 e 2015 do manuseio de carvão, coque e $\mathrm{PCI}$ no terminal portuário da CSN e analisados, de forma a adquirir informações necessárias para o entendimento e representação do sistema a ser simulado.

A análise de dados consistiu de avaliar o Statement of Facts - SOF dos navios que operaram no terminal, que contempla as principais informações: nome do navio, data e hora em que o navio chega na barra, em que é aceito, quando vai em direção ao berço, quando atraca, início e fim das operações, o total descarregado e o tipo de produto. A partir desse documento foi realizada a extração dos dados, que possibilitou a análise da linha do tempo dos navios dentro do processo de descarga. A partir dos

SOF's dos navios foi possível tabular e transportar os dados em uma planilha de Excel, para maior entendimento e análise. Uma amostra dessa planilha é apresentada na Tabela 1. 
Tabela 1 - Exemplo do banco de dados obtidos através dos SOF's

\begin{tabular}{|c|c|c|c|c|c|c|c|c|c|c|}
\hline Vessel's Name & Berth & Arrival Roads & NOR Tendered & NORAccepted & Pillot On Board & Berthing & Discharging Commenced & Discharging completed & Cargo (T) & Product \\
\hline Ocean Tomo & 101 & 14/01/2014 18:55 & 14/01/2014 18:55 & 14/01/2014 18:55 & $31 / 01 / 201417: 15$ & 31/01/2014 20:00 & 01/02/2014 11:30 & 04/02/2014 18:00 & $33.000,570$ & COKE \\
\hline Belo Horizonte & 101 & 26/01/201401:06 & 26/01/201401:06 & 26/01/201401:06 & 06/02/201411:00 & 06/02/2014 14:00 & 06/02/2014 22:45 & 10/02/2014 19:30 & $55.000,000$ & COKE \\
\hline EMS & 101 & 02/02/201405:00 & 02/02/201405:00 & 02/02/201405:00 & 13/02/201413:42 & 13/02/2014 17:20 & 14/02/201401:00 & 20/02/2014 18:00 & $72.868,000$ & COAL \\
\hline Maritime Seto Shio & 0101 & 09/02/201421:42 & 09/02/201421:42 & 09/02/201421:42 & 23/02/2014 18:42 & 23/02/2014 22:00 & 23/02/201423:00 & 26/02/201403:30 & $31.360,320$ & COKE \\
\hline Bahia I & 101 & 13/02/201413:00 & 13/02/201413:00 & 13/02/201413:00 & 04/03/2014 10:25 & 04/03/2014 13:55 & 04/03/2014 16:10 & 08/03/2014 19:15 & $55.000,000$ & COKE \\
\hline Santa Paula & 101 & 26/02/201412:00 & 26/02/2014 12:00 & 26/02/201412:00 & 11/03/2014 11:25 & $11 / 03 / 201414: 30$ & 11/03/201422:00 & 16/03/201402:00 & $70.919,000$ & COAL \\
\hline Liberty Dawn & 101 & 05/03/201403:45 & 05/03/201403:45 & 05/03/201403:45 & 17/03/201409:06 & 17/03/2014 12:25 & 17/03/2014 17:30 & 21/03/2014 18:00 & $77.000,000$ & COAL \\
\hline Grizzly & 101 & 05/03/201417:45 & 05/03/2014 17:55 & 05/03/2014 17:55 & 26/03/201413:00 & 26/03/2014 16:00 & 26/03/201420:00 & 30/03/2014 10:30 & $77.040,597$ & COAL \\
\hline Magda P & 101 & 06/03/2014 14:00 & 06/03/2014 14:00 & 06/03/2014 14:00 & 31/03/201421:05 & 01/04/2014 00:40 & 01/04/201402:00 & 03/04/2014 11:30 & $33.199,800$ & COAL \\
\hline Wei Fong & 101 & 16/03/201402:09 & 16/03/201402:09 & 16/03/201402:09 & 06/04/201402:47 & 06/04/2014 06:20 & 06/04/201407:25 & 10/04/2014 23:50 & $52.600,000$ & COKE \\
\hline Archigetis & 101 & 23/03/201406:30 & 23/03/201406:30 & 23/03/201406:30 & $16 / 04 / 201416: 30$ & $16 / 04 / 201419: 30$ & 16/04/2014 19:30 & 22/04/201409:30 & $76.455,292$ & $\mathrm{PCl}$ \\
\hline
\end{tabular}

Fonte: Autor

A Tabela 1 exemplifica as informações extraídas dos SOF's dos navios, consolidadas em um banco de dados, com as seguintes informações:

- Vessel's Name: nome do navio;

- Berth: identificação do berço que o navio atracou;

- Arrival Roads: data e hora exata que o navio chega fora de barra;

- NOR Tendered: momento exato que o comandante envia o documento, sinalizando sua chegada na barra;

- NOR Accepted: momento exato que o terminal reconhece a chegada do navio;

- Pilot on Board: data e hora exata que o Prático sobe a bordo do navio para realizar a manobra de atracação no berço;

- Berthing: data e hora exata que o navio atraca no berço;

- Discharging Commenced: data e hora exata que inicia o processo de descarga do navio;

- Discharging Completed: data e hora exata que termina o processo de descarga do navio;

- Cargo (t): total de carga a bordo do navio;

- Product: qual tipo de produto o navio está transportando. 
A partir desta planilha destacada na Tabela 1, verificou-se que deveriam ser consideradas, para os anos de 2014 e 2015, as operações de 109 embarcações, com descarregamento dos navios variando de 22.000 a 78.553 toneladas. Foram considerados os seguintes itens que compõe a linha de tempo:

- Análise de tamanho de navios: Conforme será apresentado na figura abaixo, os navios variam devido a diversos motivos, tais como:

- Características do porto de origem;

- Características do porto de destino;

- Tipo de carga movimentada;

- Custo do frete marítimo;

- Custo da carga transportada, entre outros.

Figura 27 - Gráfico com o tamanho dos navios movimentados no terminal

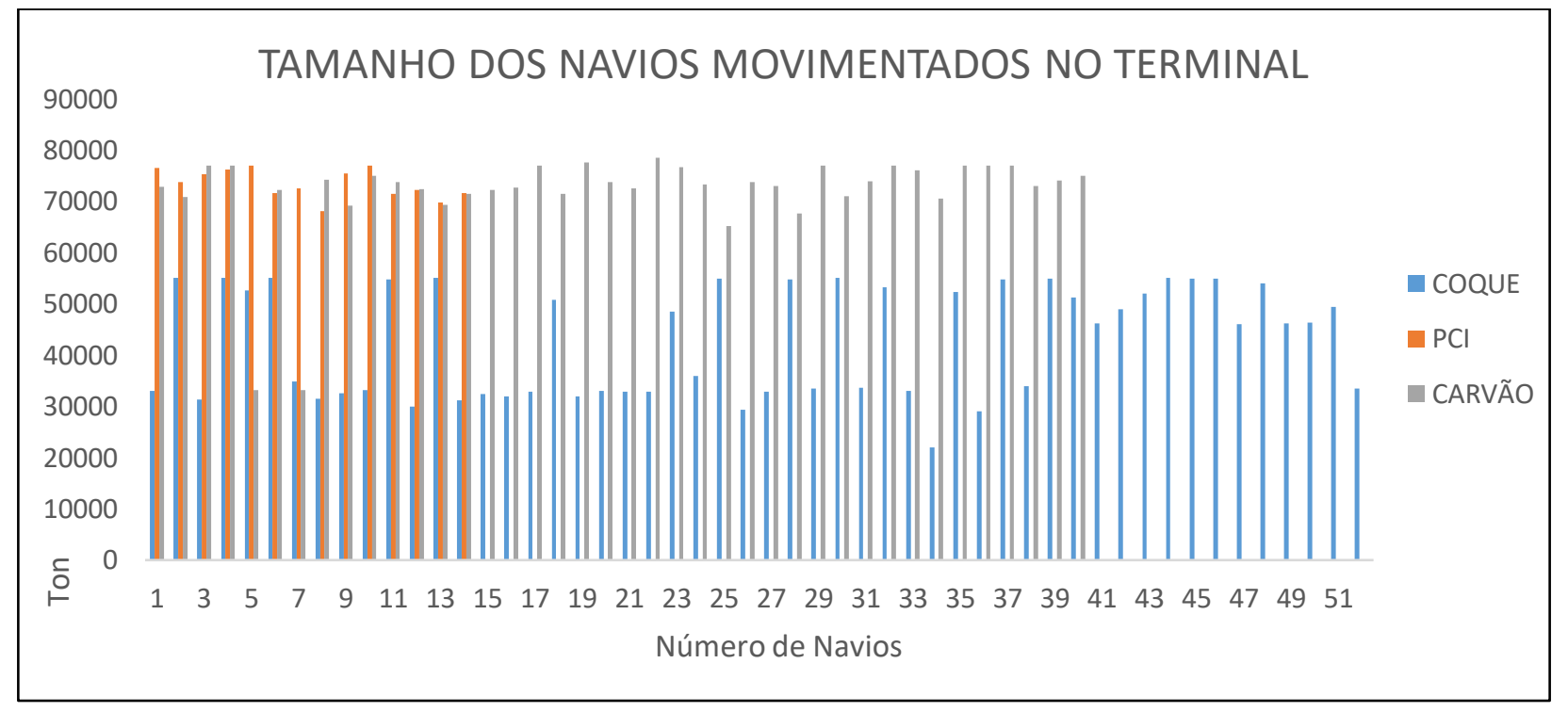

Fonte: Autor

Pode ser observado que os navios que transportam $\mathrm{PCl}$ e Carvão, são navios de tamanhos médios de 70.000 mil toneladas, enquanto navios que transportam Coque possuem capacidade que varia entre 30.000 a 50.000 mil toneladas. Em análise com a área comercial da companhia, essa variação se deve ao fato da distinção de dois grandes fornecedores. Navios que possuem tamanhos de 30.000 mil toneladas são 
trazidos da Colômbia, onde a companhia desenvolveu um fornecedor, e possui um contrato de longo prazo, já navios de tamanho de 50.000 toneladas são de diversos fornecedores da China.

- Análise de chegadas de navios: a chegada do navio no porto, é dada a partir do aceite da Notice of Readiness - NOR pelo terminal. Esse aceite consiste em sinalizar o comandante do navio que todos os documentos necessários para atracação estão aceitos pelo porto. A partir dessa etapa, inicia-se assim a estadia do navio no terminal.

- Tempo em fila: período compreendido entre o aceite da NOR e a hora em que o prático dá início à manobra de atracação no berço, denominado Pilot on Board.

A Figura 28 mostra os resultados da análise dos tempos em fila dos navios no terminal no período analisado.

Figura 28 -Histograma de tempos médio em fila dos navios

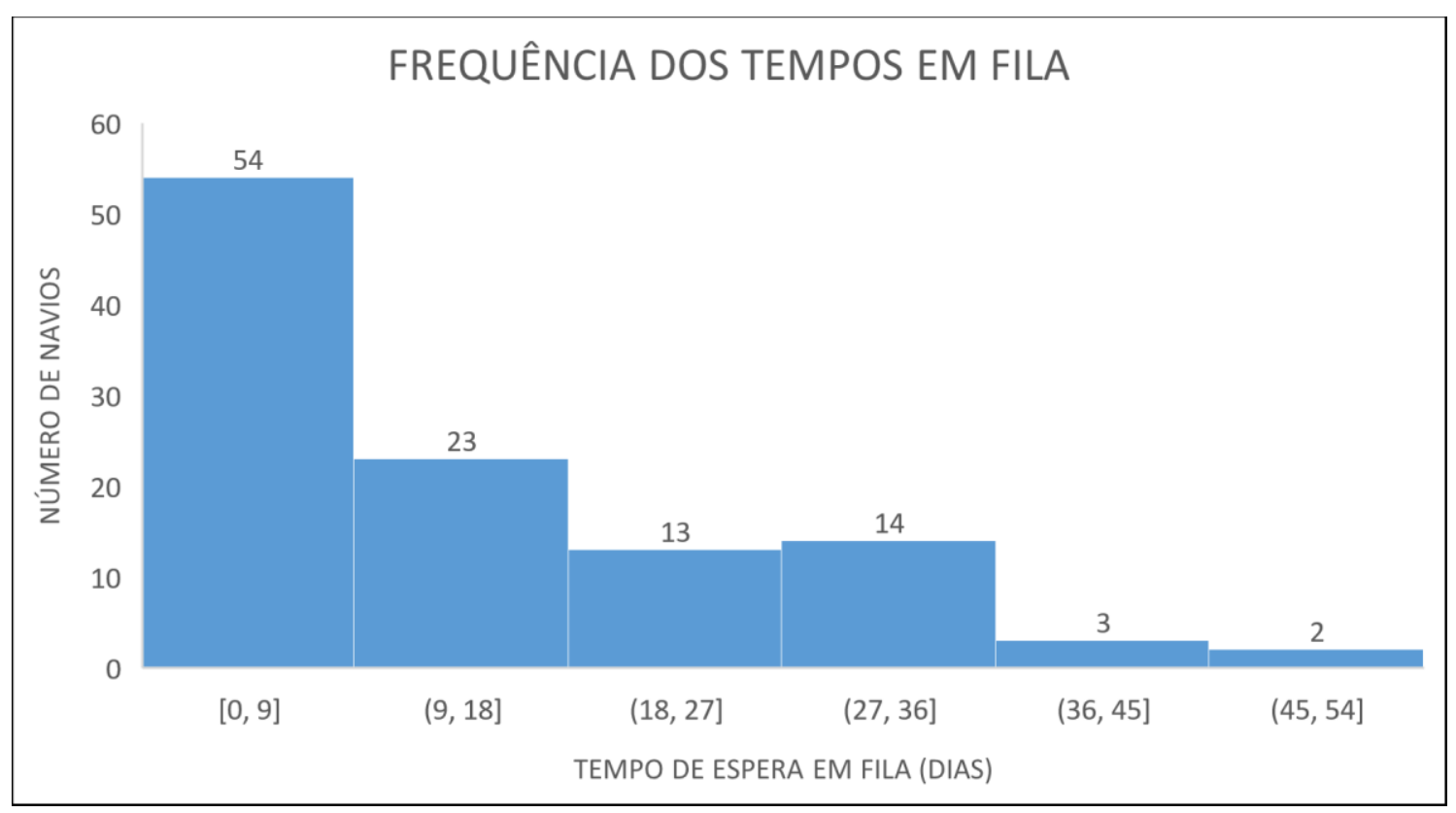

Fonte: Autor 
Pode-se observar que a maioria dos navios, mais precisamente 54 navios, estiveram seu tempo de fila entre 0 e 9 dias, enquanto a média de tempo da mesma etapa são de 12,57 dias. O deslocamento da média em relação aos navios com maior frequência acontece, pois há um grande número de eventos que ocorrem em tempos maiores que a média.

- Taxa comercial (Ton/Hrs): Consiste em avaliar a performance da descarga do navio, dividindo a tonelagem descarregada pelo tempo total da estadia do navio no berço, considerando todas as paralizações operacionais como, por exemplo, troca de porão, retirada de lastro além, das paralizações por corretivas de manutenção como, por exemplo, quebras de equipamentos do sistema de descarga.

Figura 29 - Taxa Comercial dos Navios

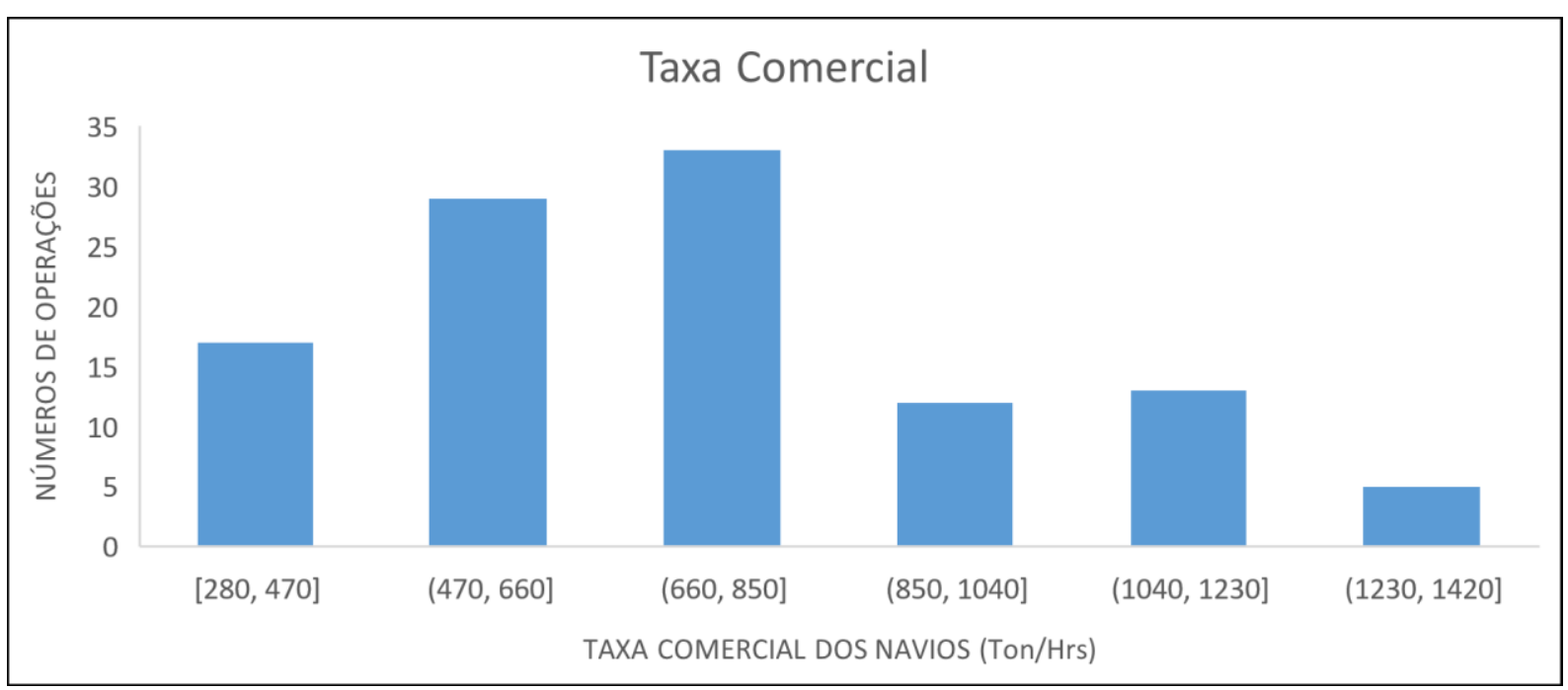

Fonte: Autor

- Taxa efetiva (Ton/Hrs): produção em toneladas do navio divido pelas horas realmente operadas. Nessa conta desconsidera as quebras durante a estadia do navio no berço bem como os impactos operacionais. 
Figura 30 - Taxa Efetiva dos Navios

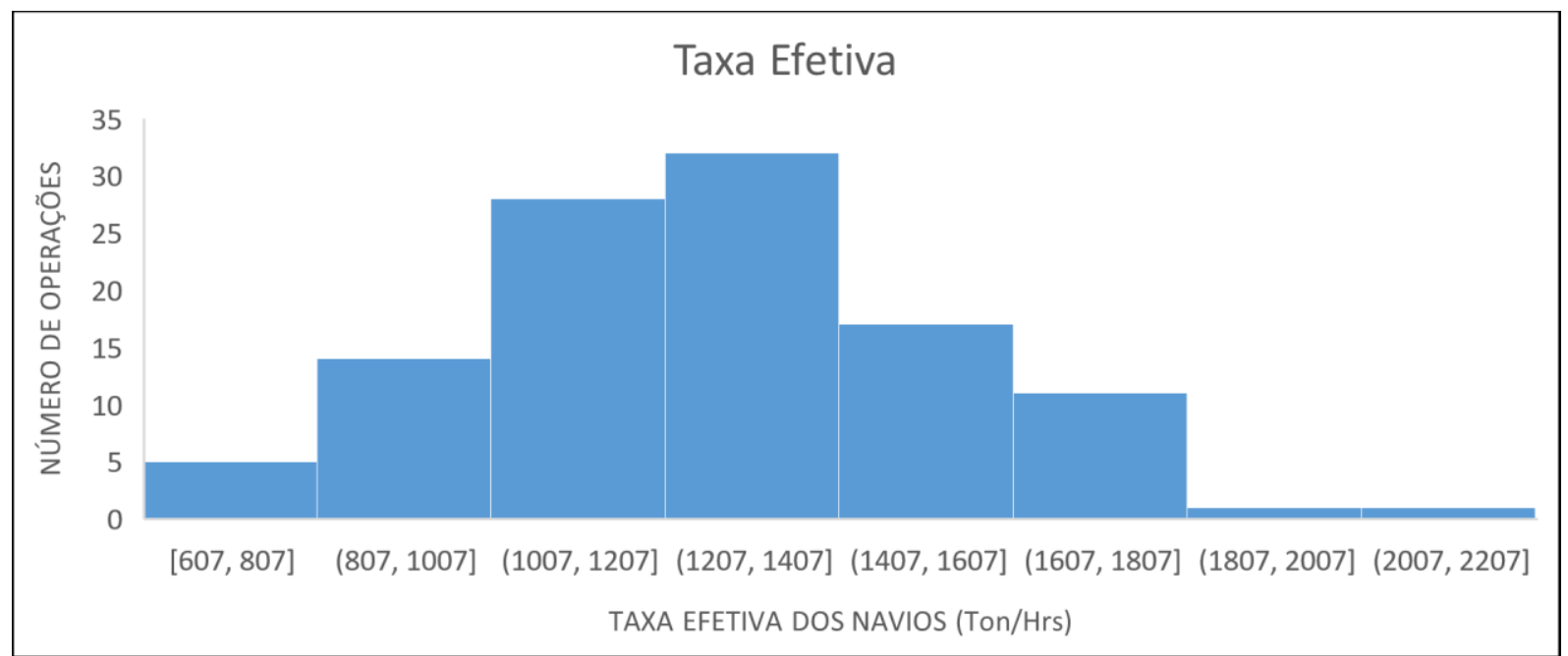

Fonte: Autor

$\mathrm{Na}$ Tabela 2 podemos observar a variação das taxas comerciais e efetivas por produtos e a taxa média dos produtos realizadas no período de 2014 e 2015. Cabe ressaltar que a taxa comercial de descarga é resultado da combinação dos 3 DN's descarregadores de navios.

Tabela 2 - Média das Taxas Comerciais e Efetivas dos Produtos

\begin{tabular}{c|cc}
\hline \multirow{2}{*}{ Data } & \multicolumn{2}{|c}{ TAXAS } \\
\cline { 2 - 3 } & Comercial & Efetiva \\
\hline DN's (Média dos Produtos) & 743 & 1.251 \\
COKE & 719 & 1.074 \\
COAL & 726 & 1.331 \\
PCl & 827 & 1.472 \\
\hline
\end{tabular}

Fonte: Autor

A taxa comercial é considerada um dos parâmetros mais importantes para considerar o modelo validado, pois, representa o nível de serviço do porto considerando o resultado da utilização dos equipamentos do terminal. 
Figura 31 - Distribuição estatística que melhor representa a taxa comercial de descarga do Terminal
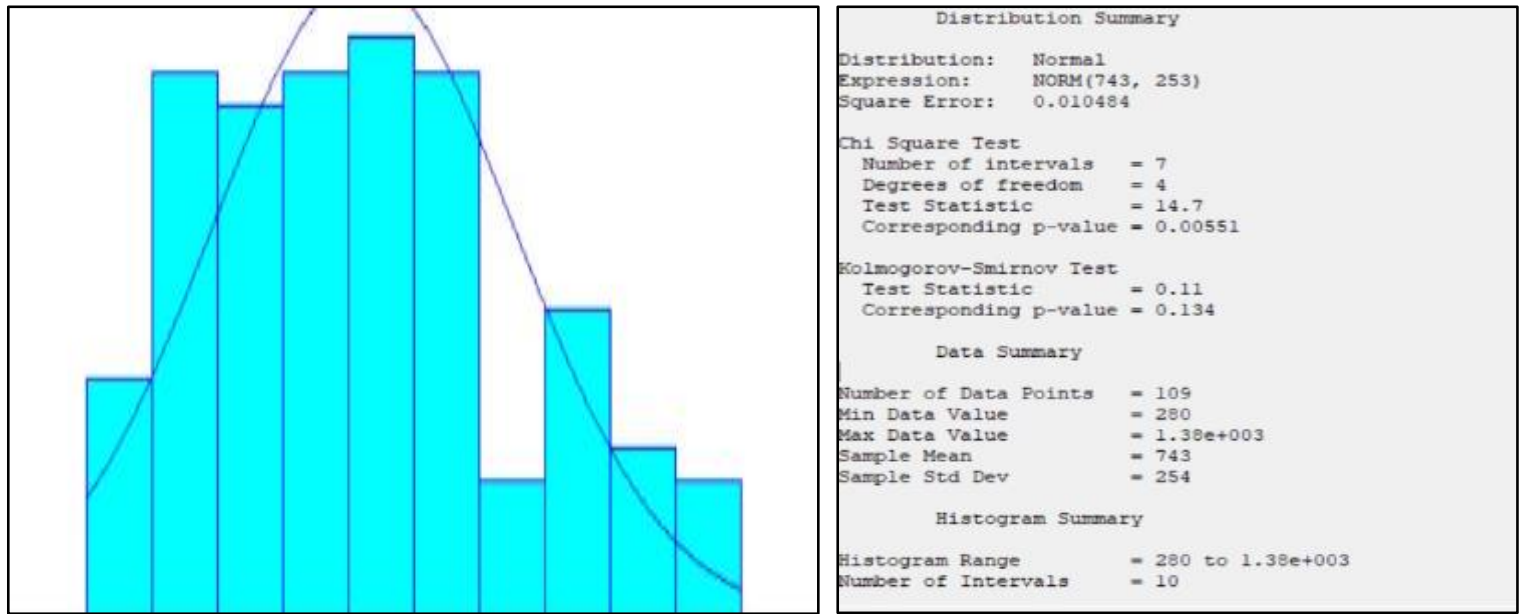

Fonte: Autor

Figura 32 - Distribuição estatística que melhor representa a taxa efetiva de descarga do Terminal
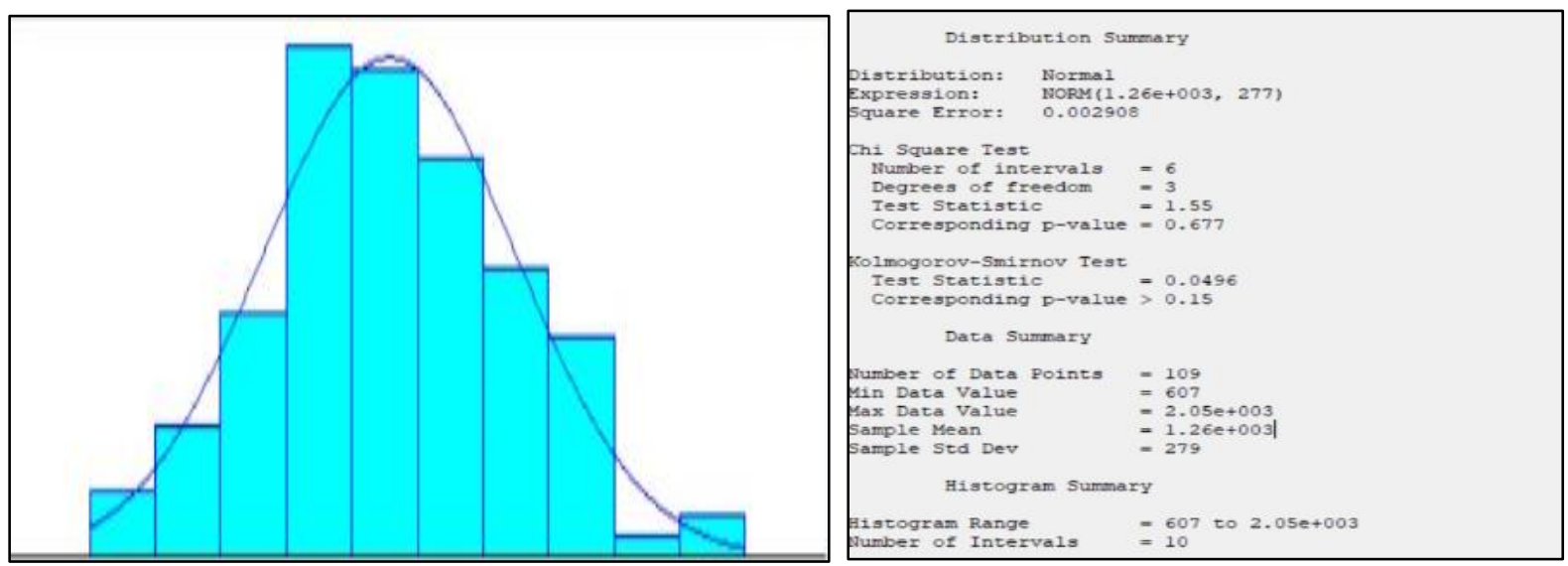

Fonte: Autor

As figuras 31 e 32, representam as análises estatísticas, geradas pelo software Arena utilizando-se da ferramenta Input Analyzer, das taxas comercial e efetiva de descarga do terminal onde demonstra que, a melhor distribuição para tais dados é a distribuição normal. Observa-se também que, em ambos os casos, os valores de $p$ value são maiores que 0,10 , o que valida a distribuição normal como representativa dos dados obtidos. As distribuições estatísticas são essências no input do modelo. 
- Manobra e atracação: essa atividade compreende o período entre a hora em que o prático toma controle do navio Pilot on Board e a Atracação Berthing.

Figura 33 - Histograma do tempo de manobras dos navios

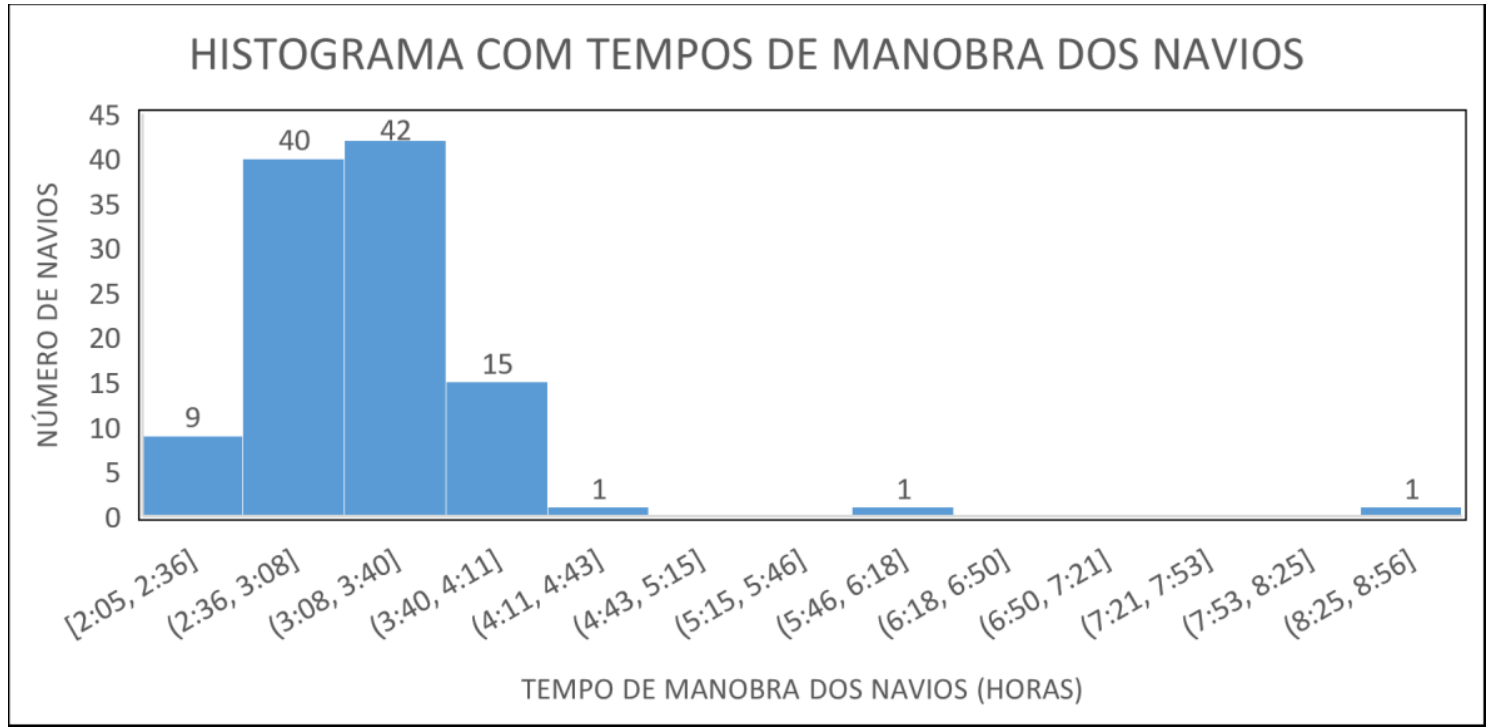

Fonte: Autor

Observa-se que a moda do tempo de manobra é de aproximadamente 3 horas e 8 minutos, enquanto a média de tempo da mesma etapa é de 3 horas e 16 minutos. Foi identificado também 2 navios que destoaram do padrão do tempo de manobras no terminal.

- Tempo de pré-operação: período compreendido entre a Atracação Berthing e o começo da Operação de Descarga Discharging Commenced. 
Figura 34 - Histograma do tempo de pré-operação dos navios no berço

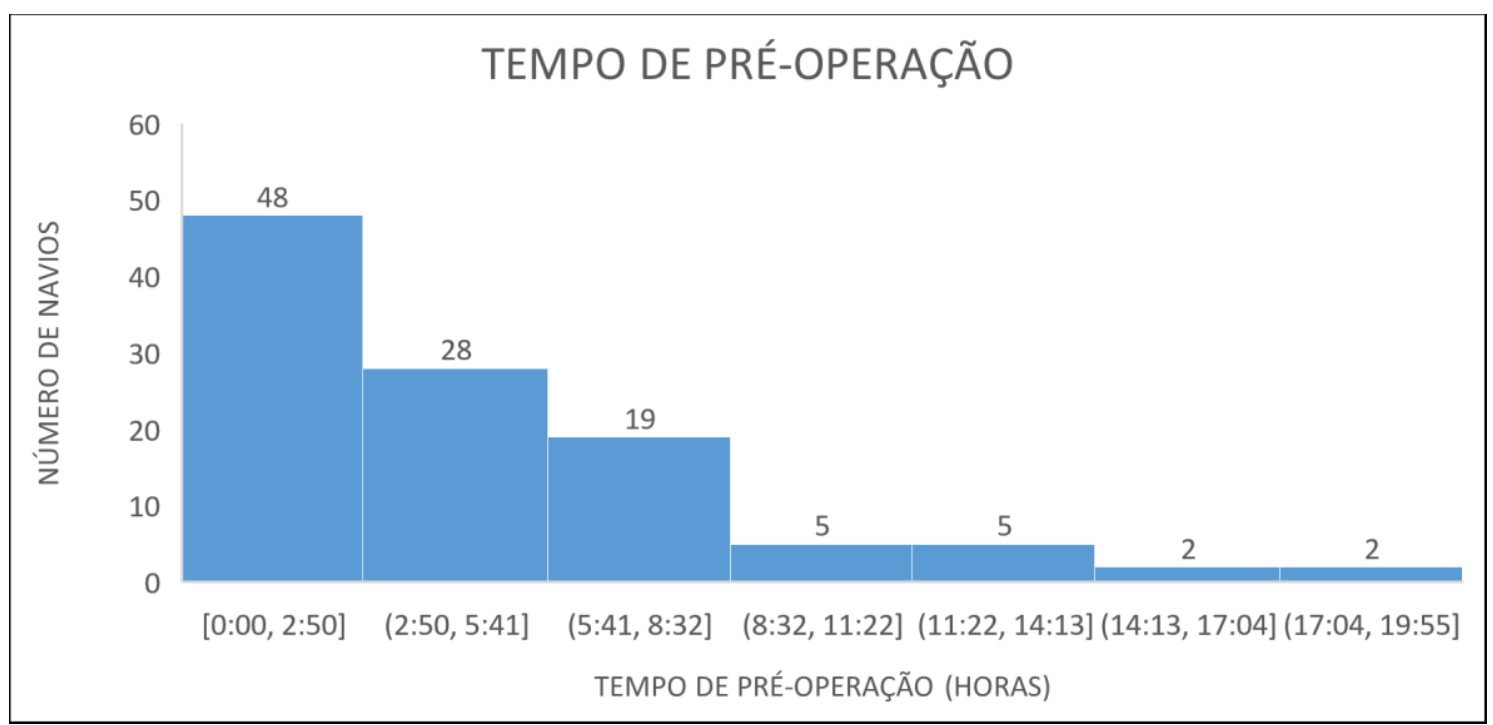

Fonte: Autor

Como pode ser observado no histograma acima, a moda do tempo de pré-operação é de aproximadamente 2 horas e 50 minutos, com média de 4 horas e 34 minutos. Porém, existem alguns (poucos) eventos com tempos muito grandes. Esse fenômeno se deve ao fato de muitas das vezes optar-se por atracar o navio no berço sem que se inicie, de fato, a operação. Pode-se elencar alguns exemplos desse tipo de evento:

- O navio atraca, mas não tem área para descarregar, portanto ele aguarda no berço;

- O navio atraca, e antes de iniciar a operação ocorre algum evento de manutenção do processo de descarga;

- O navio atraca para que possa ser feito alguma inspeção de vigilância sanitária, do órgão da ANVISA.

- Tempo de operação: período compreendido entre o começo Discharging Commenced e o final Discharging Completed da operação de descarga no porto. 
Figura 35 - Histograma de tempo de operação dos navios no berço

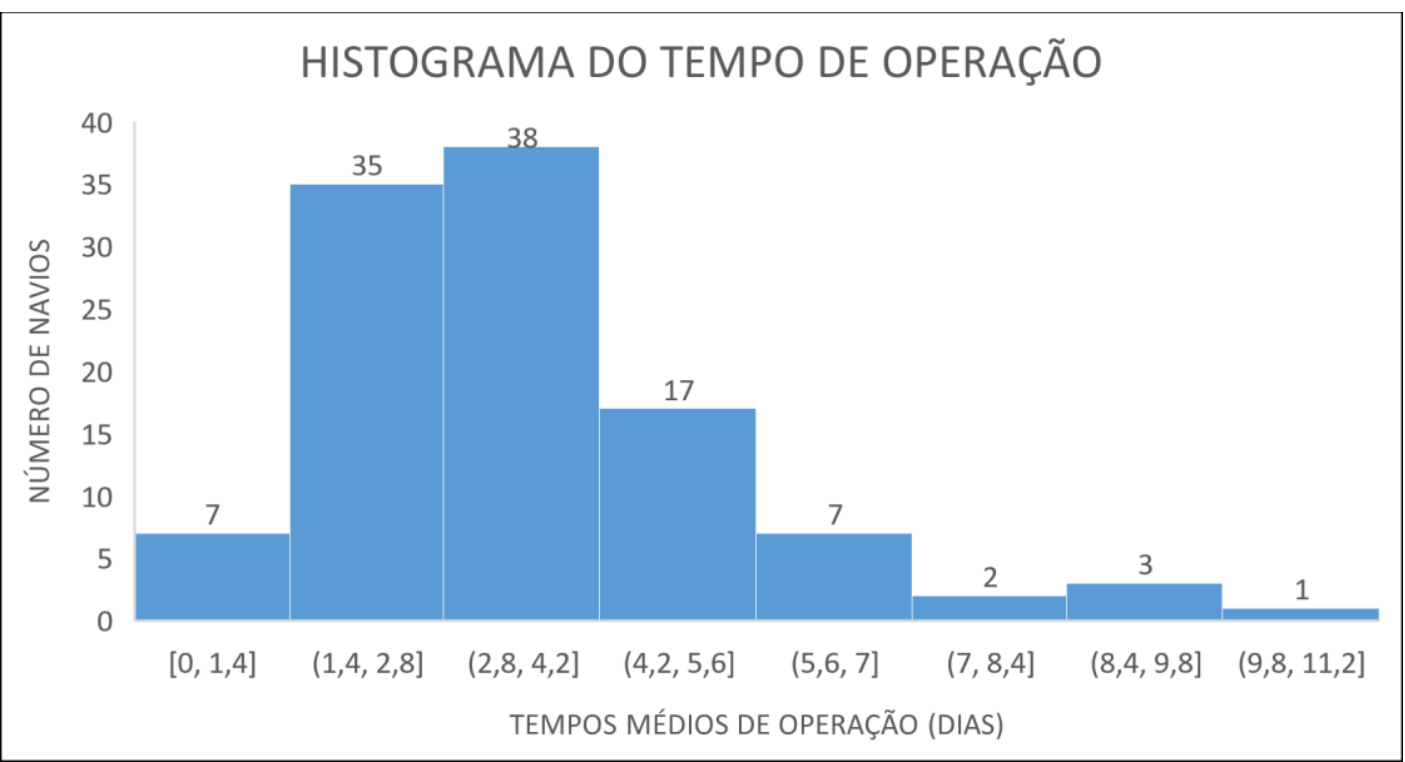

Fonte: Autor

A média do tempo de operação no terminal no período analisado foi de aproximadamente 3,5 dias. A fim de alcançar a curva que melhor caracteriza a distribuição da amostra, obteve-se na figura abaixo a logarítmica normal, com média de 3,5 dias desvio padrão de 1,54 e erro quadrático de 0,204 (dados em número de dias).

Figura 36 - Distribuição estatística que melhor representa o tempo de operação do navio

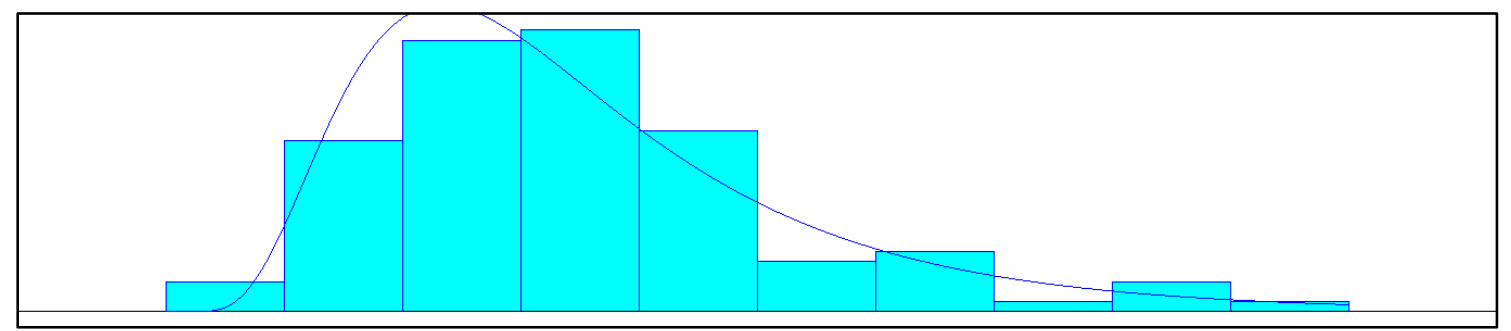

Fonte: Autor

Após todas as análises realizadas da linha do tempo no navio em todo o sistema portuário, foram analisados também os tempos médios de recarga ferroviária do terminal para expedição do trem para abastecimento da usina. 
- Tempo recarga ferroviária é o período compreendido entre o início da recarga e o final da recarga. Estes dados foram consolidados e estão apresentados no gráfico abaixo:

Figura 37 - Gráfico do tempo de operação do processo de recarga de trens

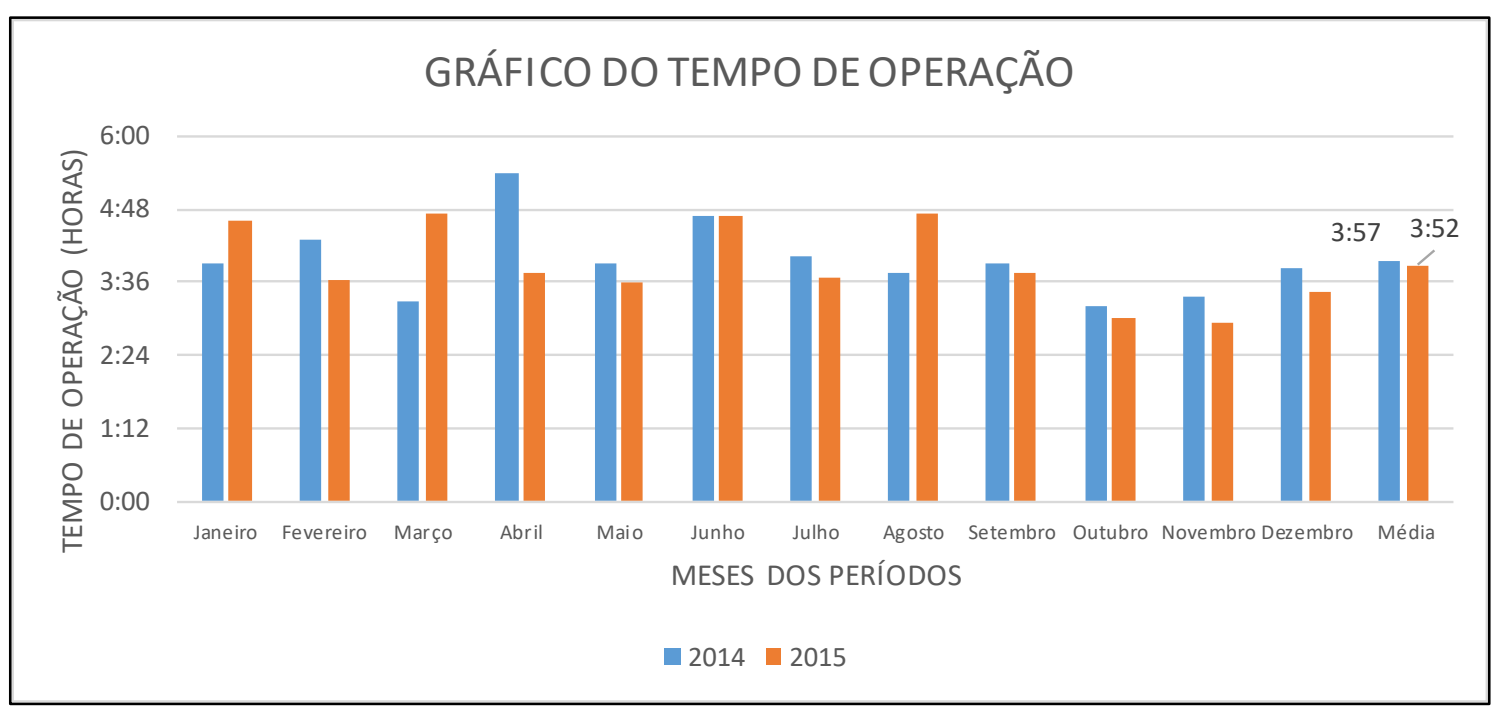

Fonte: Autor

A transferência dos insumos do Porto para a Usina, foi analisada a fim de identificar a capacidade do trem, em toneladas, de acordo com as características de cada produto.

A análise de definição do tamanho do lote é importante pois, existe uma variação de densidade dos produtos. Essa variação é possível ver na Figura 38. 
Figura 38 - Gráficos com a capacidade de carga dos trens por produtos

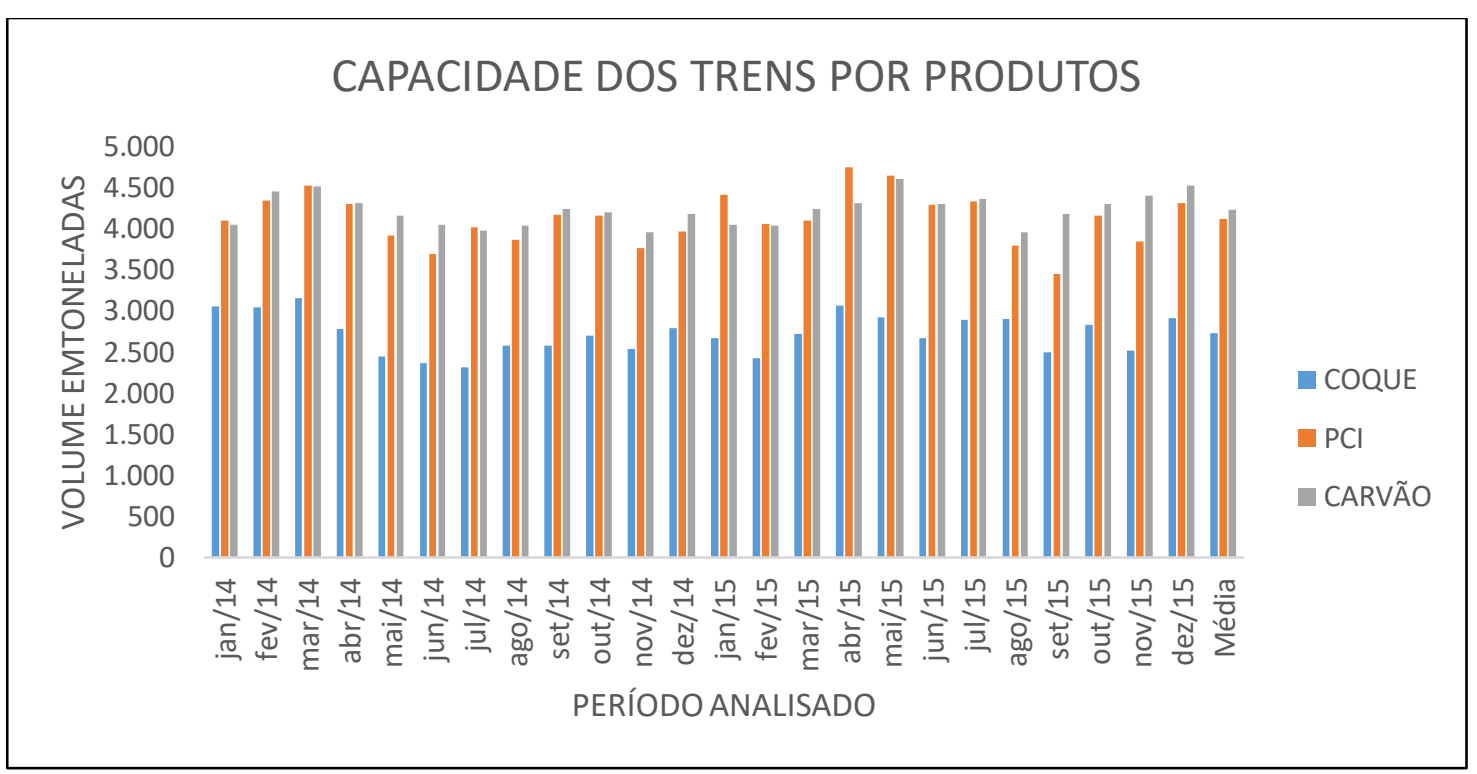

Fonte: Autor

- Taxa de consumo da USINA: o percentual de consumo da usina foi considerado a carga toda descarregada no período analisado de aproximadamente 6 milhões de toneladas, divido pelo período de análise da pesquisa. Os valores considerados se encontram na Tabela 3.

Tabela 3 - Consumo médio diário da usina

\begin{tabular}{|l|c|c|c|c|}
\hline Produto & ID & Total recebido & Queima Diária & $\%$ \\
\hline COKE & 0 & 2.230 .847 & 3.187 & $36 \%$ \\
\hline PCl & 1 & 1.028 .460 & 1.469 & $17 \%$ \\
\hline COAL & 2 & 2.865 .383 & 4.093 & $47 \%$ \\
\hline Total & & 6.124 .691 & 8.749 & $100 \%$ \\
\hline
\end{tabular}

Fonte: Autor 
Análise do lead time por produtos: para essa análise foram utilizadas informações no SCOPO, programa que detém todas as informações do navio, desde seu carregamento no porto de origem até seu descarregamento no porto de Itaguaí. Foi realizado também uma entrevista, através de questionário que constam nos apêndices C e D, com a área de interface com a comercial da companhia, a fim de identificar todo o processo de compra dos redutores para abastecimento da usina. As etapas destacadas são:

- Transit Time dos navios por produto: foi considerada a data de atracação no terminal da CSN (-) o primeiro dia de lay day do navio no porto de origem. Em média as janelas de lay days, são fornecidas para o navio no porto de origem com 10 dias, podendo variar de acordo com o tipo de contrato;

- Tempo médio de negociação do produto: em média 10 dias;

- Negociação do frete marítimo: em média levam-se 30 dias;

- Lead time dos produtos: a soma de todos esses tempos por navios compôs os tempos de lead time por produtos.

O conjunto de todas essas informações, compuseram o resultado dos dados de lead time dos produtos, descritas nas figuras abaixo:

Como pode ser observado na Figura $39,80 \%$ das cargas de PCl estão contemplados entre 70 a 80 dias, ou seja, a partir do momento que a usina identifica a necessidade de um produto desse material, ela informa à área comercial que inicia o processo de aquisição do produto. Vale ressaltar que muitas das vezes esse processo direto da usina com a área comercial não leva em consideração as variáveis de toda cadeia logística. 
Figura 39 - Percentual das faixas de probabilidades do lead time de PCl

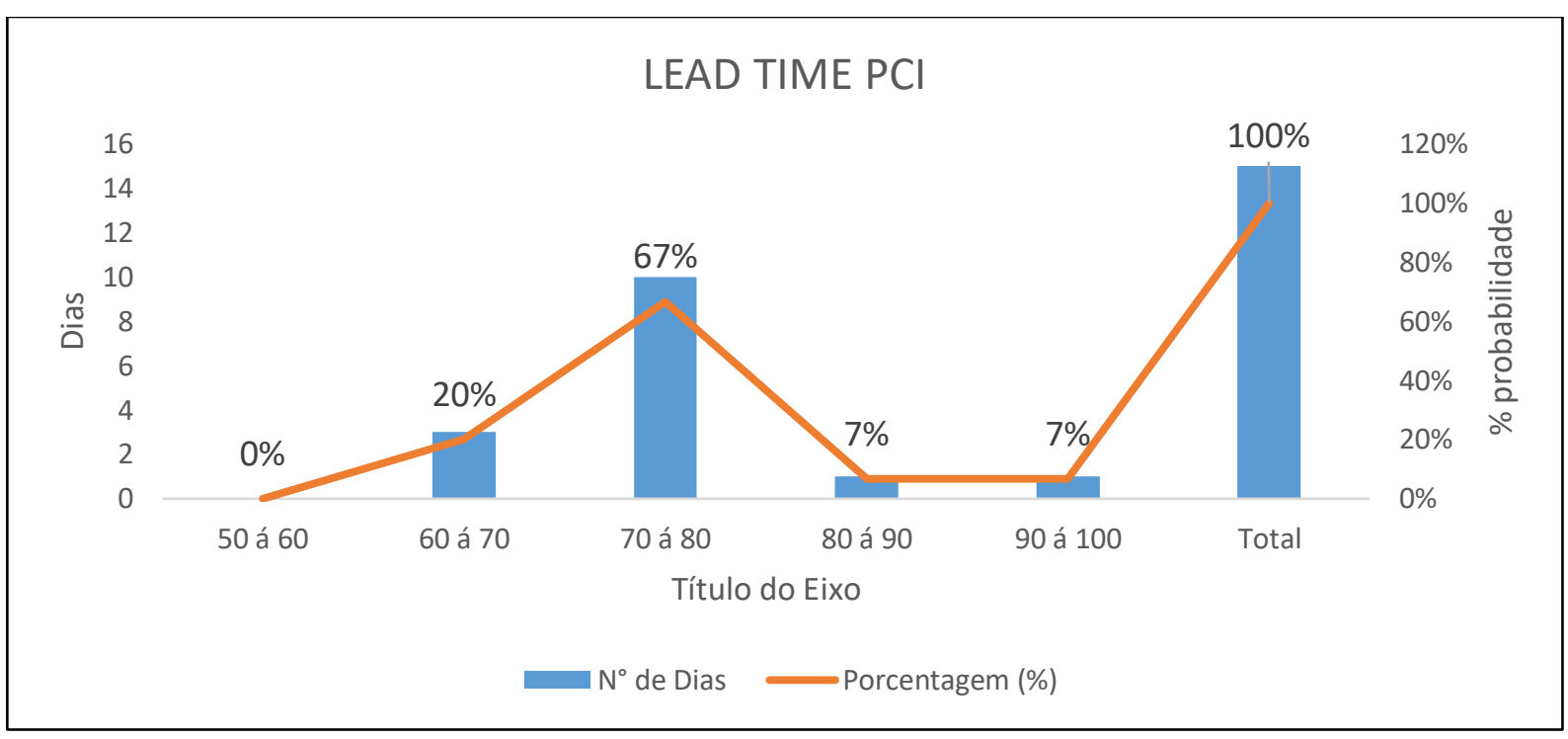

Fonte: Autor

Referente ao lead time do produto de carvão, conseguimos identificar uma variação maior, o que nos remete a quantidade de fornecedores existentes no mercado. Fato é que $50 \%$ dos produtos de carvão tem o seu lead time entre 60 a 70 dias.

Figura 40 - Percentual das faixas de probabilidades do lead time de carvão

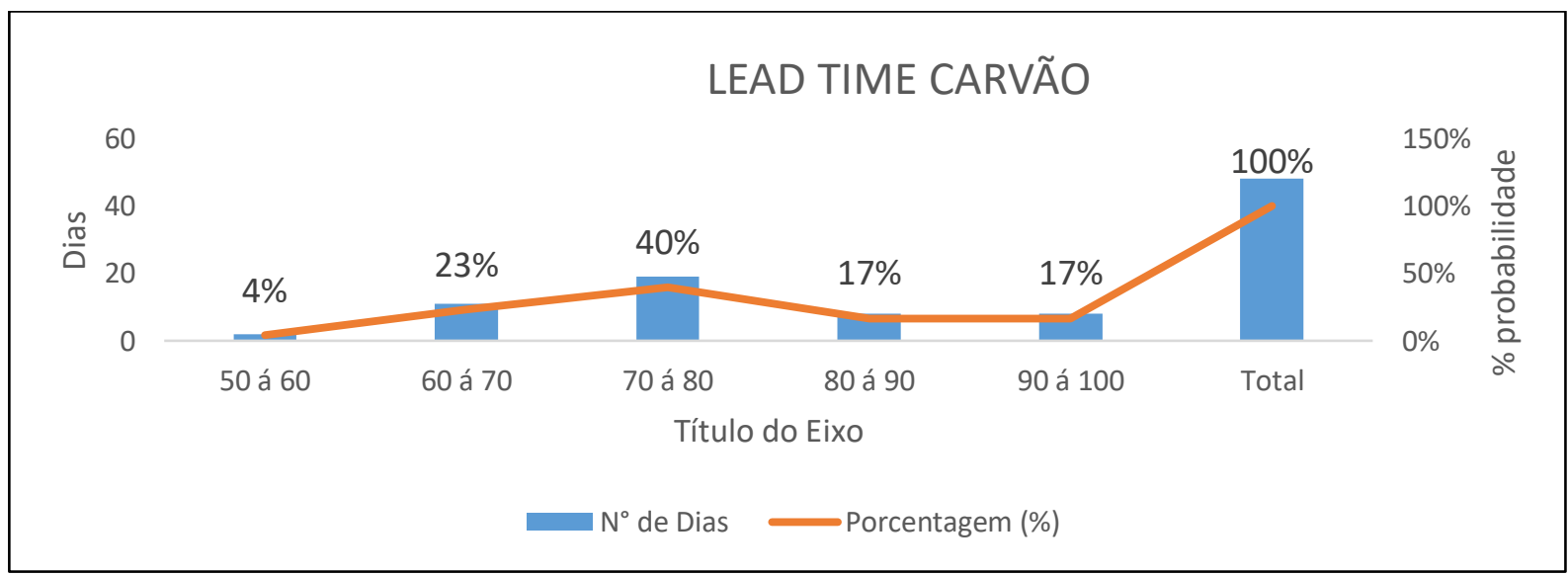

Fonte: Autor 
Por fim, a análise referente ao produto de coque, consiste também em uma variação similar ao produto de carvão. Aproximadamente $40 \%$ dos produtos desse material encontram-se na faixa entre 60 a 70 dias.

Figura 41 - Percentual das faixas de probabilidades do lead time de coque

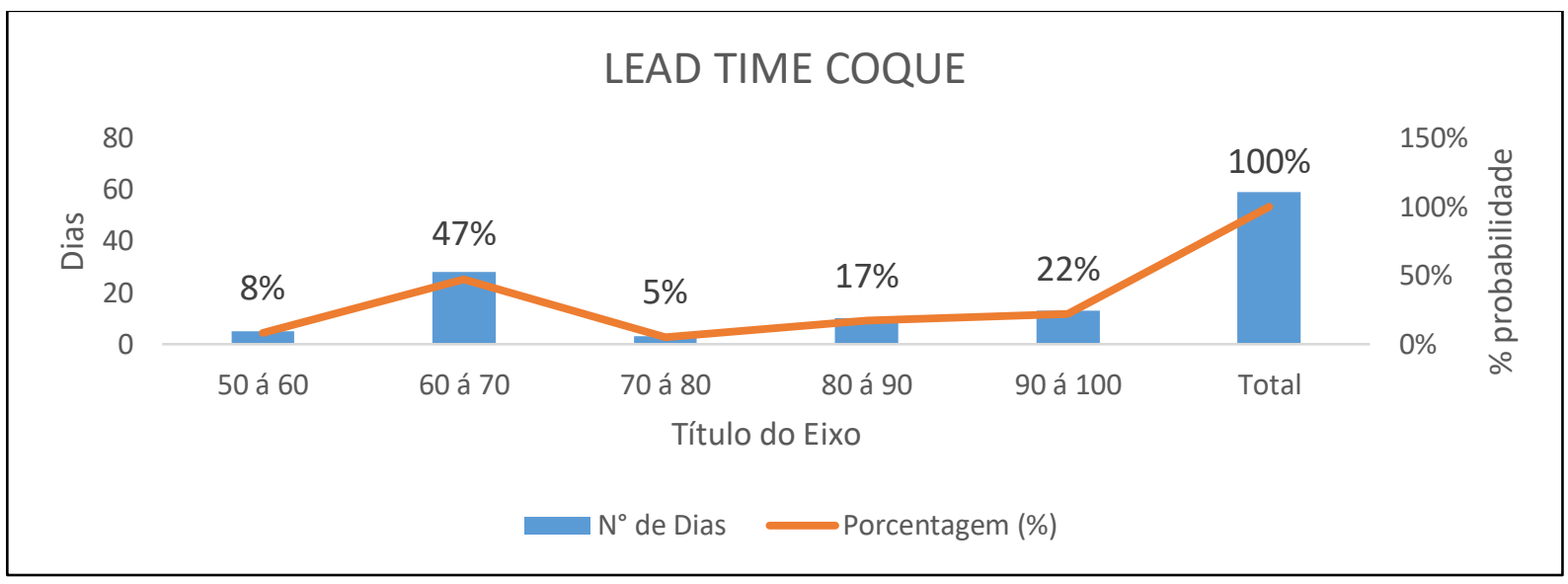

Fonte: Autor

A partir da estratificação desses dados e do entendimento da distribuição de probabilidades do lead time de cada produto, para o cenário 2 proposto na definição de cenários, item 3.7 desse trabalho, foi possível substituir a taxa exponencial de chegada de navios pela taxa de probabilidade das faixas de lead time estocásticos de cada produto, consequentemente respeitando a estocasticidade do modelo

\subsection{CENÁRIO BASE}

O cenário base de validação refere-se ao período de 2014 e 2015, das operações realizada no TECAR, do sistema de importação de redutores. Neste período foram atendidos 109 navios, movimentando aproximadamente 6 milhões de toneladas no terminal. Em médias os navios tiveram 3,6 dias de operação com uma taxa comercial de 743 toneladas/hora. 
Considerando esses valores, foi determinado que o cenário base deveria atender esses indicadores chaves, considerando as premissas apresentadas a seguir, que foram incorporadas ao modelo, na Tabela 4.

Tabela 4 - Tabela de premissas cenário base

\begin{tabular}{|c|c|c|c|}
\hline DESCRIÇÃO & \multicolumn{3}{|c|}{ PRODUTO } \\
\hline ID Produto & 0 & 1 & 2 \\
\hline Produto & Coque & $\mathrm{PCl}$ & Carvão \\
\hline Consumo Diário (toneladas) & 3.187 & 1.469 & 4.093 \\
\hline Capacidade do Navio (toneladas) & 50.000 & 70.000 & 70.000 \\
\hline Tempo de pós-operação (horas) & 1 & 1 & 1 \\
\hline Tempo de desatracação (horas) & 2 & 2 & 2 \\
\hline Estoque Inicial Usina (toneladas) & 94.106 & 59.554 & 22.340 \\
\hline Estoque Inicial Porto (toneladas) & 39.000 & 46.592 & 129.808 \\
\hline Capacidade Trem (toneladas) & 2.800 & 4.300 & 4.300 \\
\hline Tempo de Carregamento Virador (horas) & 4 & 4 & 4 \\
\hline Tempo de Descarregamento Virador Usina (horas) & 8 & 8 & 8 \\
\hline Tempo de viagem Porto-Usina (horas) & 6 & 6 & 6 \\
\hline Tempo de viagem Usina-Porto (horas) & 6 & 6 & 6 \\
\hline Capacidade de estoque da Usina (toneladas) & & 220000 & \\
\hline Capacidade de estoque do Porto (toneladas) & & 260000 & \\
\hline Estoque de segurança (dias) & & 30 & \\
\hline Número de trens no ciclo (unidade) & & 4 & \\
\hline Quantidade de berços (unidade) & & 1 & \\
\hline Quantidade de carregador ECV (unidade) & & 1 & \\
\hline Quantidade de virador usina (unidade) & & 1 & \\
\hline Fator para liberar navio & & $100 \%$ & \\
\hline
\end{tabular}

Fonte: Autor 
Algumas dessas premissas foram estabelecidas durante a entrevista conduzida com colaboradores da empresa, que possuem interface com as áreas comercial e a área de planejamento da usina. Por exemplo, tempo de viagem porto usina, o tempo médio conhecido nessa operação por sentido são de 6 horas. As filas foram desconsideradas pelo fato de a operação ser programada sem interferência externa, uma vez que o trecho é dedicado entre porto e usina. O tempo de descarga do trem no virador da UPV, foi considerado 8 horas de duração, informação repassada pela área técnica e operacional da usina.

Em relação às características dos navios que foram atendidos no porto, foram considerados navios médios de carvão e PCI na ordem de 70.000 toneladas e para operação de coque 50.000 toneladas, baseado na análise de tamanhos de navios.

Foram levantados também no dia inicial da data de simulação do primeiro navio, os estoques na usina e no porto, conforme gráficos abaixo:

Figura 42 - Estoque inicial porto e usina

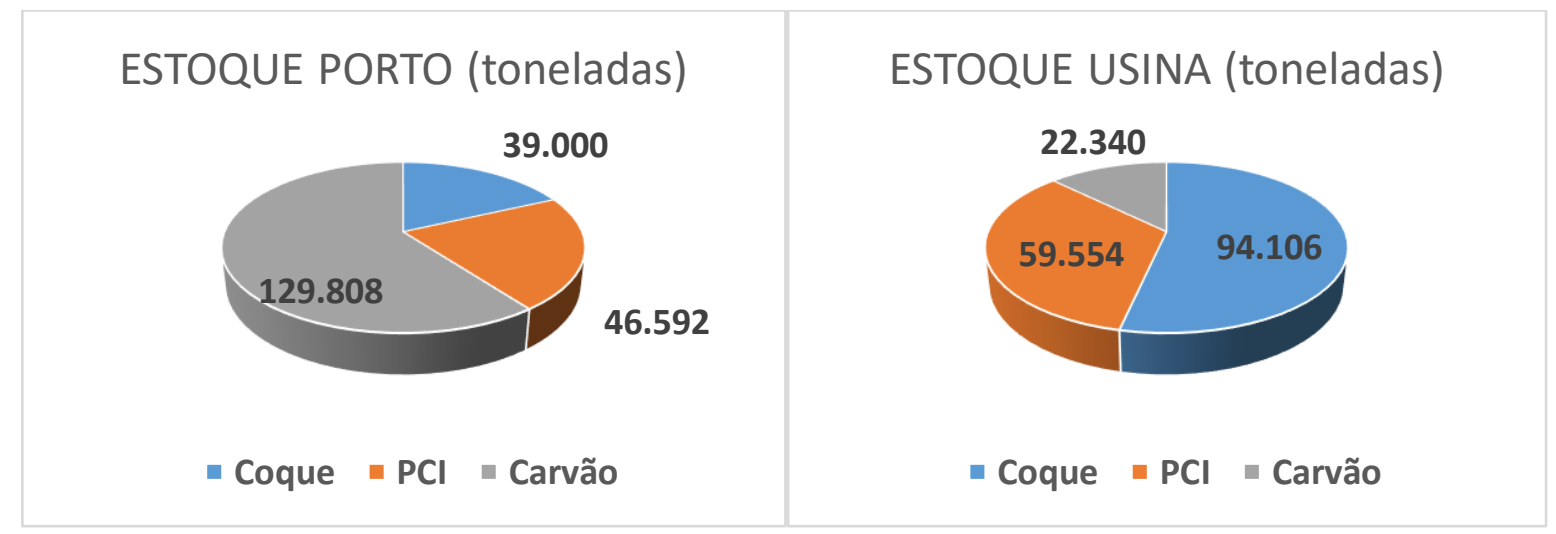

Fonte: Autor 


\subsection{RESULTADO DE VALIDAÇÃO}

A validação do modelo Port Discharge, incidiu de uma série de simulações, realizadas para atender os indicadores de validação, conforme os dados reais.

Este processo consistiu de avaliar o sistema portuário, sendo que este é o mais restritivo no sistema, considerando uma visão integrada, pois o processo de envio para Usina acontece após a carga estar disponibilizada no estoque do pátio no porto. Deste modo, neste estudo foi considerado que o porto é o elemento principal dessa cadeia logística. Assim, uma vez que os resultados de validação do sistema portuário correspondessem ao sistema real portuário, considerou-se que o modelo estava válido.

Para a validação foram considerados os navios do statemenet of facts - SOF's, que atracaram nos anos de 2014 e 2015. Os dados foram tratados para que navios que voltaram à barra fizessem apenas uma atracação, com os novos dados inseridos na planilha de Log de validação, que faz com que nessa etapa o modelo seja determinístico e sem as variáveis estocásticas de chegada de navios, aleatoriedades de tamanhos de navios por exemplo, ou seja, nessa etapa foram utilizados os dados reais de movimentação no terminal.

Desse documento foram extraídos os NOR Tendered como chegadas dos navios no modelo e as cargas reais. Além de terem sido calculados os tempos de fila, manobra de atracação, pré-operação e operação.

No modelo foram utilizados os dados reais de manobra, pré-operação e taxa como input, além de terem sido respeitados a ordem de chegada real. Os outputs foram analisados a partir do primeiro ponto em que a fila zerou em ambos os sistemas, no navio número 50, denominado "Aquila". O modelo respondeu tempo médio em fila de 6,89 dias e uma ocupação do berço de 64,7\%, desde o início, enquanto a realidade mostrou 7,26 dias e ocupação de 64,4\%. O motivo do descarte dos dados de fila é a necessidade do warm-up do modelo. Na realidade o primeiro navio analisado já acumulava 17 dias de fila, enquanto no modelo este mesmo navio é recém-criado. 
Isso faz com que seja necessário aquecer e descartar os primeiros resultados até que o sistema entre em regime permanente, o que acontece após 300 dias de operação comparando o log de output do modelo com os dados reais.

A Tabela 5, apresenta os resultados do cenário de validação do modelo.

Tabela 5 - Cenário de validação

\begin{tabular}{|l|c|c|c|c|}
\hline \multicolumn{1}{|c|}{ DESCRIÇÃO } & UNIDADES & VALIDAÇÃO & REAL & DESVIO \\
\hline Número de navios atendidos & Und. & 109 & 109 & $0 \%$ \\
\hline Número de navios gerados & Und. & 109 & 109 & $0 \%$ \\
\hline Taxa de descarga & Und. & 748 & 743 & $1 \%$ \\
\hline Tempo médio de navio em fila & Dias & 6,89 & 7,26 & $5 \%$ \\
\hline Tempo médio de atracação & Horas & 3,26 & 3,16 & $3 \%$ \\
\hline Tempo médio de pré-operação & Horas & 3,96 & 4,34 & $10 \%$ \\
\hline Tempo médio de operação & Dias & 3,47 & 3,50 & $1 \%$ \\
\hline Taxa de ocupação de berço & $\%$ & $65 \%$ & $64 \%$ & $0,5 \%$ \\
\hline
\end{tabular}

Fonte: Autor

Pode-se observar que os desvios ou erros entre o modelo computacional e o sistema real ficaram na ordem, entre $0 \%$ a $10 \%$. O critério para adoção de validade do modelo avaliou que o limite percentual de erros deveria estar na faixa de $10 \%$.

Netto et al. (2015) descreve que, quando o modelo é construído, é necessário verificar se as lógicas e regras existentes foram implementadas de forma correta, se o modelo representa corretamente o sistema que estamos estudando. Essa verificação de validade de um modelo de simulação é chamada de validação e deve ser feita por meio de índices de desempenho e outros parâmetros obtidos na análise de dados reais de operação do sistema. 
Assim como aplicado no paper de Netto et al. (2015), este trabalho considerou um erro absoluto máximo de $10 \%$ entre os dados obtidos pela empresa (proprietária do terminal) e os resultados do modelo de simulação.

Deste modo foi considerado que o modelo computacional estava apto e validado para simular cenários de demanda que envolvesse também o processo de carregamento para a Usina, conforme será visto a seguir.

\subsection{CENÁRIOS SIMULADOS}

A operação do sistema integrado usina porto, requer uma visão sistêmica das variáveis que podem influenciar na tomada de decisão da melhor forma de contratação ou encomenda de navios em função dos produtos demandado pela Usina.

Para testar o impacto dessas variáveis, foram definidos em conjunto com as áreas de interesse da companhia, dois cenários de simulação.

CENÁRIO 1: neste cenário foi considerado o intervalo de chegada de navios regido por uma distribuição exponencial, conforme mostrado na Figura 44. O modelo verifica o balanço de massa a cada 6 meses e garante o volume de acordo com a chegada exponencial dos navios. Os outros parâmetros relativos ao sistema foram considerados os mesmos conforme mostrados na tabela dos parâmetros de entrada de validação.

CENÁRIO 2: nesse cenário a geração exponencial de navios foi substituída por um sinal em função da taxa de consumo da Usina, que dispara um comando de necessidade de navio considerando a distribuição lead times conforme mostrado na Figura 39, Figura 40, Figura 41. Nessa configuração, a variável de estoque de segurança é bastante importante pois, através dela e de sua manipulação, é possível identificar a fila atual no terminal. Ou seja, a encomenda de navios leva em consideração o lead time mais a cobertura em dias dos produtos nos pátios de armazenagem. 


\subsubsection{Resultados dos cenários simulados}

A Tabela 6 apresenta os resultados do cenário 1 e 2. Estes são resultados considerando as características descriminadas anteriormente.

Tabela 6 - Cenários simulados

\begin{tabular}{|l|c|c|}
\hline DESCRIÇÃO & CENÁRIO 1 & CENÁRIO 2 \\
\hline Tempo médio de fila de navios & 19,30 & 13,07 \\
\hline Tempo médio de ocupação do berço & 4,21 & 4,28 \\
\hline Tempo médio de operação do berço & 3,84 & 3,91 \\
\hline Tempo médio de estadia do navio & 23,60 & 17,49 \\
\hline Tempo médio de fila de trens no carregador & 0,95 & 0,98 \\
\hline Tempo médio de fila de trens no virador & 0,25 & 0,18 \\
\hline Ocupação do berço & $65 \%$ & $67 \%$ \\
\hline Ocupação dos trens & $72 \%$ & $68 \%$ \\
\hline Ocupação dos carregador & $38 \%$ & $39 \%$ \\
\hline Ocupação dos virador & $76 \%$ & $77 \%$ \\
\hline Dias que a Usina ficou sem ao menos um dos produtos & 28 & 1 \\
\hline Dias que a Usina ficou com estoque de ao menos um dos produtos abaixo da segurança & 78 & 166 \\
\hline Dias que a Usina ficou sem estoque do Produto 0 & 13 & 0,5 \\
\hline Dias que a Usina ficou sem estoque do Produto 1 & 27 & 0,5 \\
\hline Dias que a Usina ficou sem estoque do Produto 2 & 21 & 0,0 \\
\hline Dias que a Usina ficou com estoque do Produto 0 abaixo da segurança & 21 & 106 \\
\hline Dias que a Usina ficou com estoque do Produto 1 abaixo da segurança & 31 & 32 \\
\hline Dias que a Usina ficou com estoque do Produto 2 abaixo da segurança & 32 & 39 \\
\hline
\end{tabular}

Fonte: Autor

\subsubsection{Cenário 1}

Observa-se pela Figura 28 que quando comparamos os resultados dos tempos em fila real com os dados da Tabela 6 - Cenários simulados, houve um aumento de 6,73 dias no tempo de espera dos navios. Isso deve-se ao fato de que a distribuição exponencial não gera os navios de forma sequencial, ou seja, as chegadas são distribuídas ao longo dos tempos, porém com a probabilidade acumulativa, podendo chegar em um determinado tempo vários navios em um curto intervalo de tempo, concentrando as chegadas e consequentemente aumentando a espera dos navios no terminal. 
Uma análise adicional que foi realizada, refere-se aos níveis de ocupação de estoque geral no sistema porto e usina. A Figura 43 representa a variação dos estoques por tipo de produto no sistema.

Figura 43 - Nível de ocupação de estoque (cenário 1)

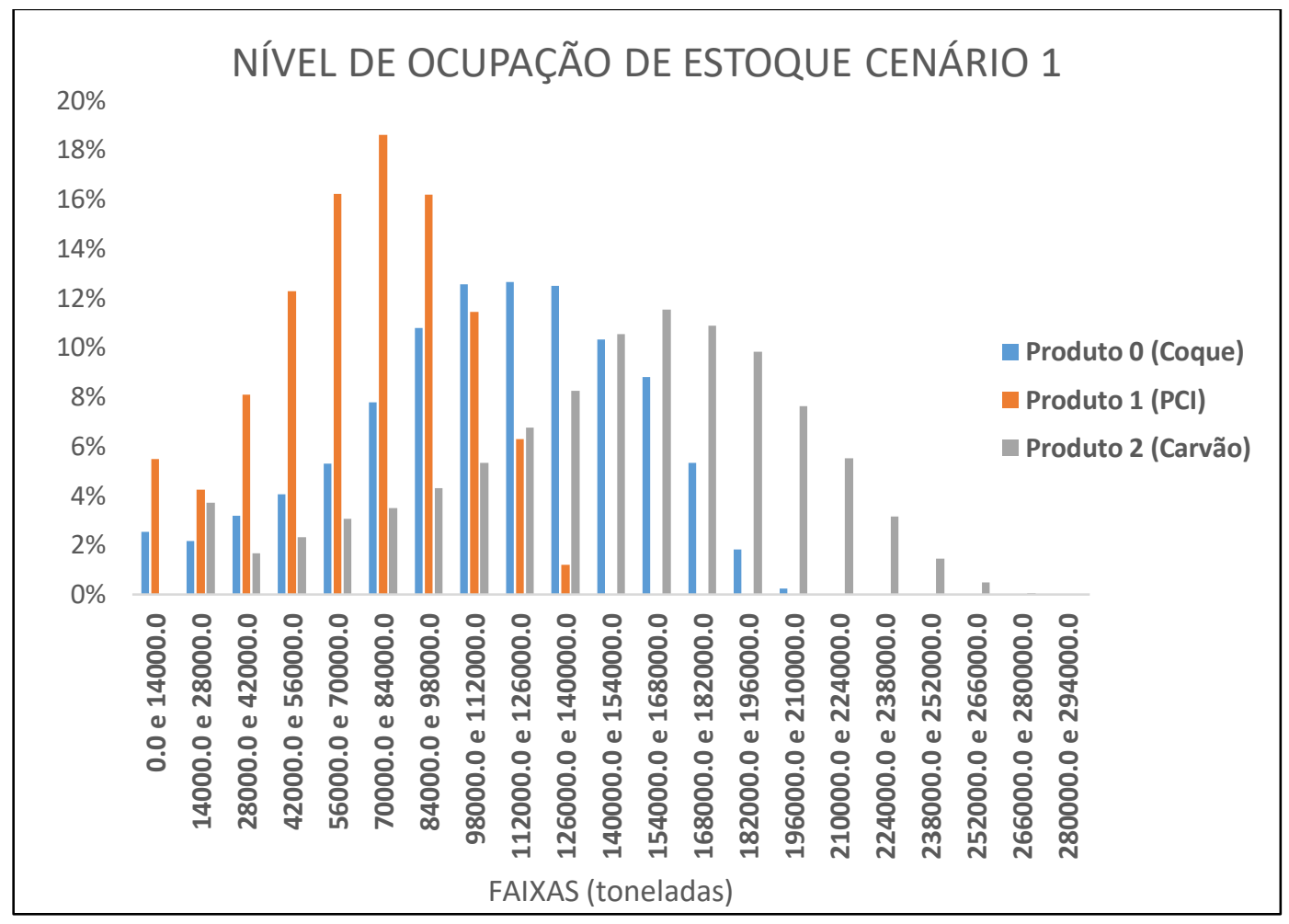

Fonte: Autor

Pode-se observar pelos resultados apresentados na Figura 43, que o produto que obteve maior ocupação no estoque, foi o produto $1(\mathrm{PCl})$ devido ao menor consumo em detrimento dos outros produtos que compõe a operação na usina. Isso tem uma correlação direta com a distribuição de chegada de navios no sistema, uma vez que pode ter ocorrido uma concentração de navios do produto 1(PCl). Esse fenômeno é claramente explicado quando, comparamos a distribuição de chegada de navios gerada pelo modelo de simulação conforme mostrado na Figura 44. 
Figura 44 - Distribuição de chegada de navios por produtos (cenário 1)

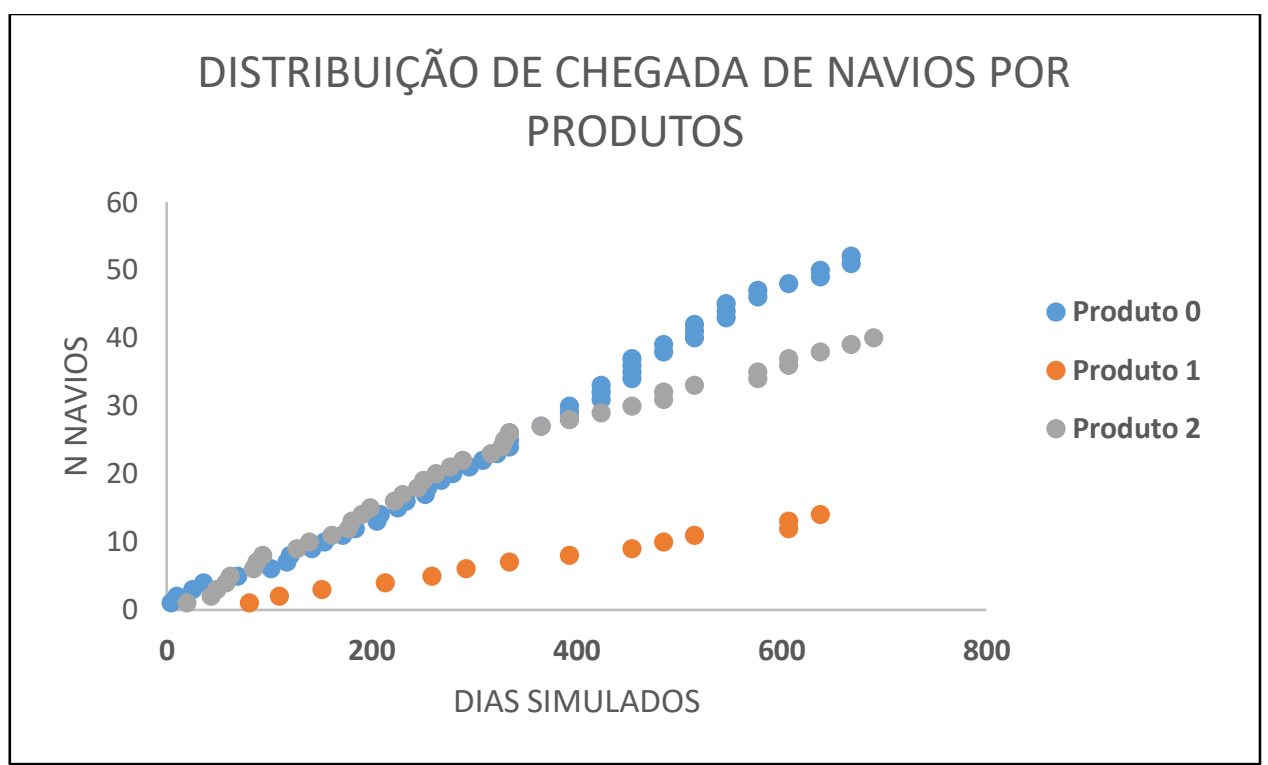

Fonte: Autor

Pode-se observar pela Figura 44 , que a distribuição de chegada de navios do produto 1 apresenta um comportamento mais espaçado em função da quantidade de produtos demandados pela Usina e pela taxa de consumo diário na ordem de 1500 tonelada/dia. Entre o primeiro e o terceiro navio o intervalo médio de chegadas é da ordem de 71 dias, quando comparados com o quarto navio, esse tempo aumenta para 133 dias. Contudo a cobertura de estoque dos 3 primeiros navios representa 140 dias, isso demostra o efeito da maior taxa de utilização dos pátios ser do produto 1, uma vez que cada navio ao chegar no porto descarrega 70 mil toneladas. Deste modo os resultados apresentados para o cenário 1 estão condizentes com a chegada de navios adotadas e seu impacto no sistema.

\subsubsection{Cenário 2}

Nota-se pela Tabela 6 que o cenário 2 desenvolvido, tem uma grande redução entre o principal índice de nível de serviço portuário, fila de navios, onde através de uma encomenda de navios atrelada ao consumo diário da usina, faz com que, apesar da chegada de navios ter uma característica de distribuição exponencial, advinda das 
probabilidades dos leads time por produtos, há um maior controle em sua chegada. A diferença na fila de navios, de aproximadamente 6 dias entre um cenário e outro, permite comprovar que essa é a melhor forma de gerir a cadeia logística de insumos. Percebe-se que, a partir de um planejamento onde se considera o lead time de cada produto, a taxa de consumo médio por produto na unidade siderúrgica e os níveis de estoques de segurança, permite uma maior integralidade de todos os elos da cadeia, havendo uma maior harmonia no sistema.

Outro ponto importante dessa análise, vai ao encontro com a cobertura de estoque e a ausência de dias em que a usina ficou sem os seus produtos. Importante reforçar ao leitor que, a falta de insumo para uma usina, pode acarretar gravíssimos problemas operacionais, inclusive paralisando seus altos-fornos.

Figura 45 - Nível de ocupação de estoque (cenário 2)

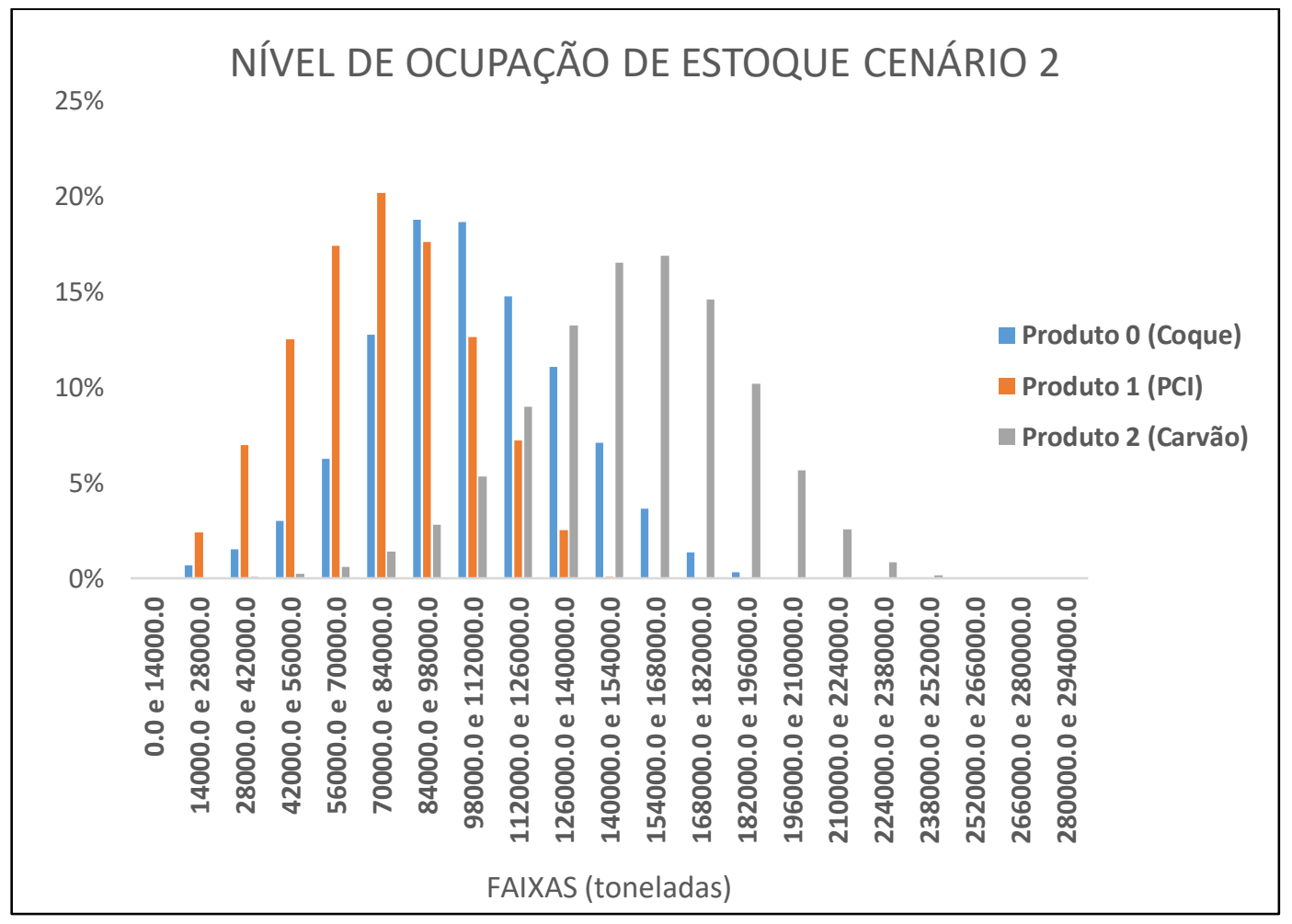

Fonte: Autor

A Figura 45 mostra que o nível de estoque dos insumos não zerou para nenhum produto e, os percentuais dos produtos de coque e carvão, por serem produtos com 
uma maior taxa de consumo, tiveram uma melhor distribuição entre as faixas de estoques. Em contrapartida, o produto de $\mathrm{PCl}$, teve uma distribuição bem similar ao primeiro cenário, com as faixas entre 14.000 a 154.000 . Por se tratar de um insumo de menor taxa de consumo e um tamanho grande de lote, com aproximadamente 70 mil toneladas no navio, esse produto acaba ficando um maior tempo nos pátios de estocagem.

O cenário 2 foi exaustivamente simulado até encontrar o estoque de segurança ótimo e condizente com a fila atual do terminal. As análises com as variações desse parâmetro, serão apresentados no item 5.6 Análise de Sensibilidade.

\subsection{ANÁLISES DE SENSIBILIDADE}

A partir do modelo ideal a ser utilizado e que configura o melhor cenário para o terminal, as análises de sensibilidade poderão requisitar a geração de novas alternativas e soluções para o problema proposto.

O primeiro cenário com as análises de sensibilidade realizadas no modelo propõe uma variação no estoque de segurança dos produtos de coque, carvão e $\mathrm{PCl}$ a fim de identificar as alterações na fila de navios do terminal.

Essas primeiras análises são referentes à possibilidade de políticas adotivas pelas equipes de gestão de estoque, compras e do terminal que podem em detrimento de uma redução de custos, assumir algum tipo de risco frente a ausência de insumos para o abastecimento e operação da Usina Presidente Vargas, compartilhadas no item 5.5.1.

Outra análise bastante comum em desenvolvimento de cenários para aumento de capacidade de um terminal portuário ou redução de fila de navios, quando o gargalo são os pátios de armazenagem, é justamente a avaliação do aumento da área de estocagem a fim de analisar o comportamento dessas variáveis. Essas avaliações estão apresentadas no item 5.5.2 desse estudo. 


\subsubsection{Análise de sensibilidade variando o estoque de segurança}

Sabe-se por conceito que a partir do momento em que se permite uma redução no estoque de segurança, o volume mínimo necessário por produtos nos estoques reduz ao ponto de aumentar a disponibilidade de área para descarga de insumos dos navios.

Outro ponto importante a ser discriminado nesse estudo é o fato de o estoque de segurança ser menor que lead time dos produtos. Esse fator faz com que a encomenda de um navio, deva ser analisada e realizada com uma antecedência considerável, aumentando a variabilidade do processo. A encomenda desses navios se dará a partir da verificação do estoque no porto e com a variabilidade da distribuição das faixas do lead time por produtos. Em média os produtos de coque, $\mathrm{PCl}$ e carvão tem seu lead time com 75, 76 e 74 dias respectivamente, sendo o que difere nesse aspecto são as probabilidades dentro das faixas de lead time de cada produto.

A relação dessa variação impacta diretamente na fila de navios no terminal e podese verificar o seu impacto na Tabela 7 e Tabela 8. 
Tabela 7 - Análise de sensibilidade - Estoque de Segurança do Cenário 2

\begin{tabular}{|c|c|c|c|c|c|c|c|c|c|c|c|c|c|}
\hline ANÁLISE DE SENSIBILIDADE - CENÁRIOS DE VARIAÇÃO DO ESTOQUE DE SEGURANÇA & cenário 2.1 & cenário 2.2 & cenário 2.3 & cenário 2.4 & cenário 2.5 & cenário 2.6 & cenário 2.7 & cenário 2.8 & cenário 2.9 & cenário 2.10 & cenário 2.11 & cenário 2.12 & cenário 2.13 \\
\hline Estoque de Segurança (dias) & 5 & 6 & 7 & 8 & 9 & 10 & 11 & 12 & 13 & 14 & 15 & 16 & 17 \\
\hline Tempo médio de fila de navios (dias) & 2,87 & 2,96 & 2,95 & 3,12 & 3,18 & 3,32 & 3,27 & 3,46 & 3,64 & 3,70 & 3,93 & 4,23 & 4,59 \\
\hline Tempo médio de ocupação do berço (dias) & 4,3 & 4,3 & 4,2 & 4,3 & 4,3 & 4,3 & 4,2 & 4,3 & 4,3 & 4,3 & 4,3 & 4,3 & 4,3 \\
\hline Tempo médio de operação do berço (dias) & 3,9 & 3,9 & 3,8 & 3,9 & 3,9 & 3,9 & 3,8 & 3,9 & 3,9 & 3,9 & 3,9 & 3,9 & 3,9 \\
\hline Tempo médio de estadia do navio (dias) & 7,3 & 7,4 & 7,3 & 7,6 & 7,6 & 7,7 & 7,6 & 7,9 & 8,0 & 8,1 & 8,3 & 8,6 & 9,0 \\
\hline Tempo médio de fila de trens no carregador (dias) & 0,73 & 0,73 & 0,72 & 0,75 & 0,76 & 0,77 & 0,77 & 0,80 & 0,82 & 0,82 & 0,85 & 0,86 & 0,88 \\
\hline Tempo médio de fila de trens no virador (dias) & 0,47 & 0,45 & 0,43 & 0,42 & 0,41 & 0,39 & 0,37 & 0,36 & 0,34 & 0,33 & 0,31 & 0,29 & 0,27 \\
\hline Ocupação do berço & $62 \%$ & $64 \%$ & $63 \%$ & $64 \%$ & $64 \%$ & $65 \%$ & $65 \%$ & $66 \%$ & $65 \%$ & $66 \%$ & $66 \%$ & $65 \%$ & $66 \%$ \\
\hline Ocupação dos trens & $81 \%$ & $82 \%$ & $80 \%$ & $80 \%$ & $80 \%$ & $80 \%$ & $78 \%$ & $79 \%$ & $77 \%$ & $76 \%$ & $75 \%$ & $74 \%$ & $73 \%$ \\
\hline Ocupação dos virador & $74 \%$ & $76 \%$ & $74 \%$ & $75 \%$ & $76 \%$ & $77 \%$ & $76 \%$ & $77 \%$ & $76 \%$ & $77 \%$ & $77 \%$ & $76 \%$ & $77 \%$ \\
\hline Dias que a Usina ficou sem ao menos um dos produtos & 46,8 & 34,4 & 40,4 & 31,3 & 27,6 & 19,6 & 23,3 & 14,0 & 18,7 & 12,8 & 12,4 & 12,9 & 9,8 \\
\hline Dias que a Usina ficou com estoque de ao menos um dos produtos abaixo da segurança & 77,9 & 74,4 & 87,9 & 85,9 & 90,2 & 89,1 & 98,0 & 94,5 & 103,5 & 100,7 & 105,1 & 106,8 & 108,1 \\
\hline Dias que a Usina ficou sem estoque do Produto 0 & 32 & 22 & 29 & 22 & 19 & 12 & 17 & 9 & 15 & 9 & 9 & 10 & 7 \\
\hline Dias que a Usina ficou sem estoque do Produto 1 & 18,0 & 8,0 & 17,1 & 10,4 & 9,3 & 3,4 & 9,8 & 2,3 & 9,0 & 4,6 & 5,4 & 6,7 & 4,7 \\
\hline Dias que a Usina ficou sem estoque do Produto 2 & 23,0 & 11,9 & 20,4 & 13,0 & 11,8 & 4,5 & 10,9 & 2,9 & 9,2 & 4,6 & 4,9 & 6,2 & 4,1 \\
\hline Dias que a Usina ficou com estoque do Produto 0 abaixo da segurança & 51 & 46,5 & 59,0 & 56,6 & 58,1 & 56,1 & 66,2 & 61,4 & 70,2 & 67,5 & 71,6 & 71,0 & 74,4 \\
\hline Dias que a Usina ficou com estoque do Produto 1 abaixo da segurança & 21 & 12 & 22 & 16 & 15 & 11 & 17 & 11 & 18 & 14 & 15 & 17 & 15 \\
\hline Dias que a Usina ficou com estoque do Produto 2 abaixo da segurança & 34 & 26 & 37 & 32 & 35 & 29 & 36 & 29 & 37 & 33 & 34 & 36 & 34 \\
\hline
\end{tabular}

\section{Fonte: Autor}


Tabela 8 - Análise de sensibilidade - Estoque de Segurança do Cenário 2

\begin{tabular}{|c|c|c|c|c|c|c|c|c|c|c|c|c|c|}
\hline ANÁLISE DE SENSIBILIDADE - CENÁRIOS DE VARIAÇÃO DO ESTOQUE DE SEGURANÇA & cenário 2.14 & cenário 2.15 & cenário 2.16 & cenário 2.17 & cenário 2.18 & cenário 2.19 & cenário 2.20 & cenário 2.21 & cenário 2.22 & cenário 2 & cenário 2.24 & cenário 2.25 & cenário 2.26 \\
\hline Estoque de Segurança (dias) & 18 & 19 & 20 & 21 & 22 & 23 & 24 & 25 & 26 & 27 & 28 & 29 & 30 \\
\hline Tempo médio de fila de navios (dias) & 5,25 & 5,59 & 6,46 & 7,17 & 8,17 & 9,26 & 10,00 & 10,89 & 12,02 & 13,07 & 14,04 & 15,07 & 16,37 \\
\hline Tempo médio de ocupação do berço (dias) & 4,3 & 4,3 & 4,3 & 4,3 & 4,3 & 4,3 & 4,3 & 4,3 & 4,3 & 4,3 & 4,3 & 4,3 & 4,3 \\
\hline Tempo médio de operação do berço (dias) & 3,9 & 3,9 & 3,9 & 3,9 & 3,9 & 3,9 & 3,9 & 3,9 & 3,9 & 3,9 & 3,9 & 3,9 & 3,9 \\
\hline Tempo médio de estadia do navio (dias) & 9,7 & 10,0 & 10,9 & 11,6 & 12,6 & 13,7 & 14,4 & 15,3 & 16,5 & 17,5 & 18,4 & 19,5 & 20,8 \\
\hline Tempo médio de fila de trens no carregador (dias) & 0,89 & 0,91 & 0,93 & 0,94 & 0,95 & 0,96 & 0,97 & 0,98 & 0,98 & 0,98 & 0,98 & 0,98 & 0,98 \\
\hline Tempo médio de fila de trens no virador (dias) & 0,26 & 0,24 & 0,22 & 0,21 & 0,20 & 0,19 & 0,19 & 0,18 & 0,18 & 0,18 & 0,18 & 0,18 & 0,18 \\
\hline Ocupação do berço & $67 \%$ & $67 \%$ & $67 \%$ & $67 \%$ & $67 \%$ & $67 \%$ & $67 \%$ & $67 \%$ & $67 \%$ & $67 \%$ & $67 \%$ & $67 \%$ & $67 \%$ \\
\hline Ocupação dos trens & $73 \%$ & $72 \%$ & $71 \%$ & $70 \%$ & $70 \%$ & $69 \%$ & $69 \%$ & $68 \%$ & $68 \%$ & $68 \%$ & $68 \%$ & $68 \%$ & $68 \%$ \\
\hline Ocupação dos carregador & $39 \%$ & $39 \%$ & $39 \%$ & $39 \%$ & $39 \%$ & $39 \%$ & $39 \%$ & $39 \%$ & $39 \%$ & $39 \%$ & $39 \%$ & $39 \%$ & $39 \%$ \\
\hline Ocupação dos virador & $78 \%$ & $78 \%$ & $78 \%$ & $77 \%$ & $77 \%$ & $77 \%$ & $77 \%$ & $77 \%$ & $77 \%$ & $77 \%$ & $77 \%$ & $77 \%$ & $77 \%$ \\
\hline Dias que a Usina ficou sem ao menos um dos produtos & 5,3 & 3,8 & 3,0 & 2,5 & 2,4 & 2,2 & 1,5 & 1,1 & 1,1 & 1,0 & 1,1 & 0,9 & 1,0 \\
\hline Dias que a Usina ficou com estoque de ao menos um dos produtos abaixo da segurança & 105,7 & 106,6 & 104,6 & 104,5 & 111,7 & 117,1 & 122,8 & 131,2 & 144,4 & 165,9 & 183,5 & 199,0 & 223,0 \\
\hline Dias que a Usina ficou sem estoque do Produto 0 & 3 & 3 & 2 & 2 & 2 & 1 & 1 & 1 & 1 & 0 & 1 & 0 & 0 \\
\hline Dias que a Usina ficou sem estoque do Produto 1 & 1,3 & 0,9 & 0,7 & 0,8 & 0,6 & 0,8 & 0,4 & 0,3 & 0,5 & 0,5 & 0,5 & 0,6 & 0,7 \\
\hline Dias que a Usina ficou sem estoque do Produto 2 & 0,7 & 0,4 & 0,3 & 0,2 & 0,1 & 0,1 & 0,0 & 0,0 & 0,0 & 0,0 & 0,0 & 0,0 & 0,0 \\
\hline Dias que a Usina ficou com estoque do Produto 0 abaixo da segurança & 70,7 & 73,1 & 70,1 & 69,0 & 76,9 & 78,9 & 83,1 & 85,4 & 92,0 & 106,1 & 115,5 & 124,4 & 135,8 \\
\hline Dias que a Usina ficou com estoque do Produto 1 abaixo da segurança & 12 & 11 & 12 & 12 & 12 & 14 & 16 & 19 & 24 & 32 & 39 & 50 & 62 \\
\hline Dias que a Usina ficou com estoque do Produto 2 abaixo da segurança & 30 & 29 & 29 & 30 & 30 & 32 & 31 & 34 & 36 & 39 & 44 & 44 & 52 \\
\hline
\end{tabular}

\section{Fonte: Autor}


A partir dessas simulações apresentadas na Tabela 7 e Tabela 8, pode-se observar em uma análise gráfica adicional o comportamento de três variáveis chaves. Quando se altera o número em dias da cobertura de estoque no porto, outras duas importantes variáveis se alteram: fila de navios e a ausência, em dias, em que a Usina ficou desabastecida sem ao menos um dos produtos.

Figura 46 - Análise de Sensibilidade - Estoque de Segurança do Cenário 2

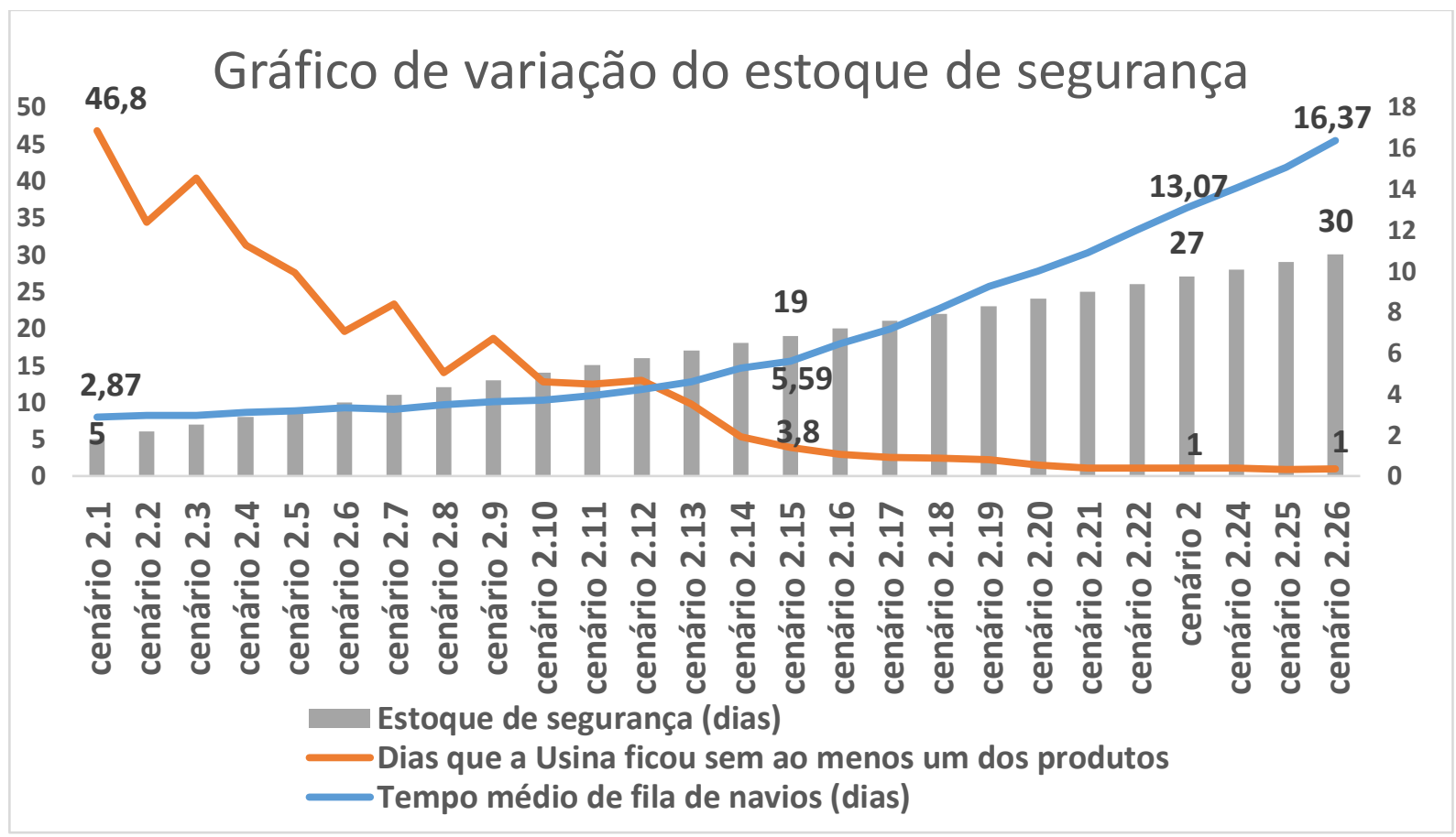

Fonte: Autor

A Figura 46, apresenta de forma bastante clara os limites de variação do estoque de segurança no porto. Pode-se interpretar que uma política de encomenda de navios, onde sua chegada considera uma cobertura de 5 dias apenas em estoque, cenário 2.1, mesmo que, com uma redução na fila para 2,87 dias, em um ano, deixará a Usina desabastecida em 46,8 dias sem ao menos um dos seus produtos no sistema, comprometendo seu processo de produção de aço.

Ao mesmo tempo, quando considerado um nível de estoque alto, a ocupação dos produtos nos pátios de armazenagem restringe, em alguns casos, que o navio 
descarregue seu produto após a sua chegada imediata no terminal, aumentando consequentemente os dias de espera dos navios em fila, pois ele deverá aguardar o consumo da usina e a redução no estoque para descarregar o seu produto.

Por outro lado, pode-se avaliar que, no cenário onde o estoque de segurança é reduzido para 19 dias por produto, cenário 2.15 , podemos verificar que a fila de navios reduz consideravelmente para 5,59 dias e, em apenas 3,8 dias, em um intervalo de um ano, ocorrerá em ausência de ao menos um dos produtos para a produção de aço na Usina.

Esse fenômeno poderá ser mitigado através de uma política de monitoramento constante do estoque e chegada dos navios onde, a equipe operacional da Usina, tendo em vista a possibilidade de desabastecimento, reduz o consumo dos insumos e consequentemente seu processo produtivo, aguardando a chegada do navio específico do produto em questão.

A análise desse risco deverá ser discutida entre todas as áreas da companhia para que se tenha um entendimento amplo da viabilidade dessa política de gestão. Acredita-se que em mais de 4 dias sem ao menos um dos produtos no terminal, poderá colocar em risco o processo produtivo da cadeia de suprimentos e consequentemente uma possível paralização da Usina.

\subsubsection{Análise de Sensibilidade Aumento de Pátio}

O segundo cenário com as análises de sensibilidade realizadas no modelo, propõe uma variação no aumento do estoque do porto, no intuito de identificar o que acontece com os outros parâmetros do sistema no terminal.

A capacidade atual do porto comporta 260.000 toneladas de insumos e a partir da variação do aumento de sua disposição, podemos identificar o impacto na variável fila de navios, conforme a Tabela 9. 
Tabela 9 - Análise de sensibilidade - Aumento de Capacidade de Estoque do Cenário 2

\begin{tabular}{|c|c|c|c|c|c|c|}
\hline ANÁLISE DE SENSIBILIDADE - CENÁRIOS DE AUMENTO DE CAPACIDADE DE ESTOQUE & Pátio Normal & \begin{tabular}{|c|} 
Aumento de \\
Pátio - $20 \%$
\end{tabular} & $\begin{array}{c}\text { Aumento de } \\
\text { Pátio - } 40 \%\end{array}$ & $\begin{array}{c}\text { Aumento de } \\
\text { Pátio- } 60 \%\end{array}$ & \begin{tabular}{|c|} 
Aumento de \\
Pátio - $80 \%$
\end{tabular} & $\begin{array}{l}\text { Aumento de } \\
\text { Pátio- } 100 \%\end{array}$ \\
\hline DESCRIÇÃO & CENÁRIO 2 & CENÁRIO 2.1 & CENÁRIO 2.2 & CENÁRIO 2.3 & CENÁRIO 2.4 & CENÁRIO 2.5 \\
\hline Capacidade do Porto & 260.000 & 312000 & 364000 & 416000 & 468000 & 520000 \\
\hline Tempo médio de fila de navios & 13,07 & 6,95 & 4,89 & 4,58 & 4,68 & 4,50 \\
\hline Tempo médio de ocupação do berço & 4,28 & 4,29 & 4,28 & 4,29 & 4,30 & 4,26 \\
\hline Tempo médio de operação do berço & 3,91 & 3,92 & 3,90 & 3,92 & 3,93 & 3,88 \\
\hline Tempo médio de estadia do navio & 17,49 & 11,37 & 9,30 & 9,01 & 9,12 & 8,89 \\
\hline Tempo médio de fila de trens no carregador & 0,98 & 1,00 & 1,00 & 0,99 & 0,99 & 0,99 \\
\hline Tempo médio de fila de trens no virador & 0,18 & 0,15 & 0,16 & 0,16 & 0,16 & 0,16 \\
\hline Ocupação do berço & $67 \%$ & $67 \%$ & $67 \%$ & $67 \%$ & $67 \%$ & $67 \%$ \\
\hline Ocupação dos trens & $68 \%$ & $67 \%$ & $67 \%$ & $67 \%$ & $67 \%$ & $67 \%$ \\
\hline Ocupação dos carregador & $39 \%$ & $39 \%$ & $39 \%$ & $39 \%$ & $39 \%$ & $39 \%$ \\
\hline Ocupação dos virador & $77 \%$ & $77 \%$ & $77 \%$ & $77 \%$ & $77 \%$ & $77 \%$ \\
\hline Dias que a Usina ficou sem ao menos um dos produtos & 1,0 & 0,5 & 0,4 & 0,6 & 0,6 & 0,5 \\
\hline Dias que a Usina ficou com estoque de ao menos um dos produtos abaixo da segurança & 166 & 106 & 112 & 118 & 114 & 118 \\
\hline Dias que a Usina ficou sem estoque do Produto 0 & 0,5 & 0,4 & 0,3 & 0,6 & 0,5 & 0,4 \\
\hline Dias que a Usina ficou sem estoque do Produto 1 & 0,5 & 0,0 & 0,1 & 0,1 & 0,0 & 0,1 \\
\hline Dias que a Usina ficou sem estoque do Produto 2 & 0,0 & 0,0 & 0,0 & 0,0 & 0,0 & 0,0 \\
\hline Dias que a Usina ficou com estoque do Produto 0 abaixo da segurança & 106 & 76 & 77 & 83 & 78 & 81 \\
\hline Dias que a Usina ficou com estoque do Produto 1 abaixo da segurança & 32 & 6 & 7 & 7 & 7 & 8 \\
\hline Dias que a Usina ficou com estoque do Produto 2 abaixo da segurança & 39 & 32 & 37 & 38 & 39 & 40 \\
\hline
\end{tabular}

\section{Fonte: Autor}


A Tabela 9 evidencia que a partir do aumento do estoque no porto, existe uma variação, somente, no indicador de fila de navios. Isso demonstra em linhas gerias que o principal gargalo do sistema hoje, é atribuído ao tamanho do estoque no terminal. A Figura 47 apresenta o gráfico da análise de sensibilidade do aumento do pátio e seu impacto na fila de navios.

Figura 47 - Análise de Sensibilidade - Aumento de Capacidade de Estoque do Cenário 2

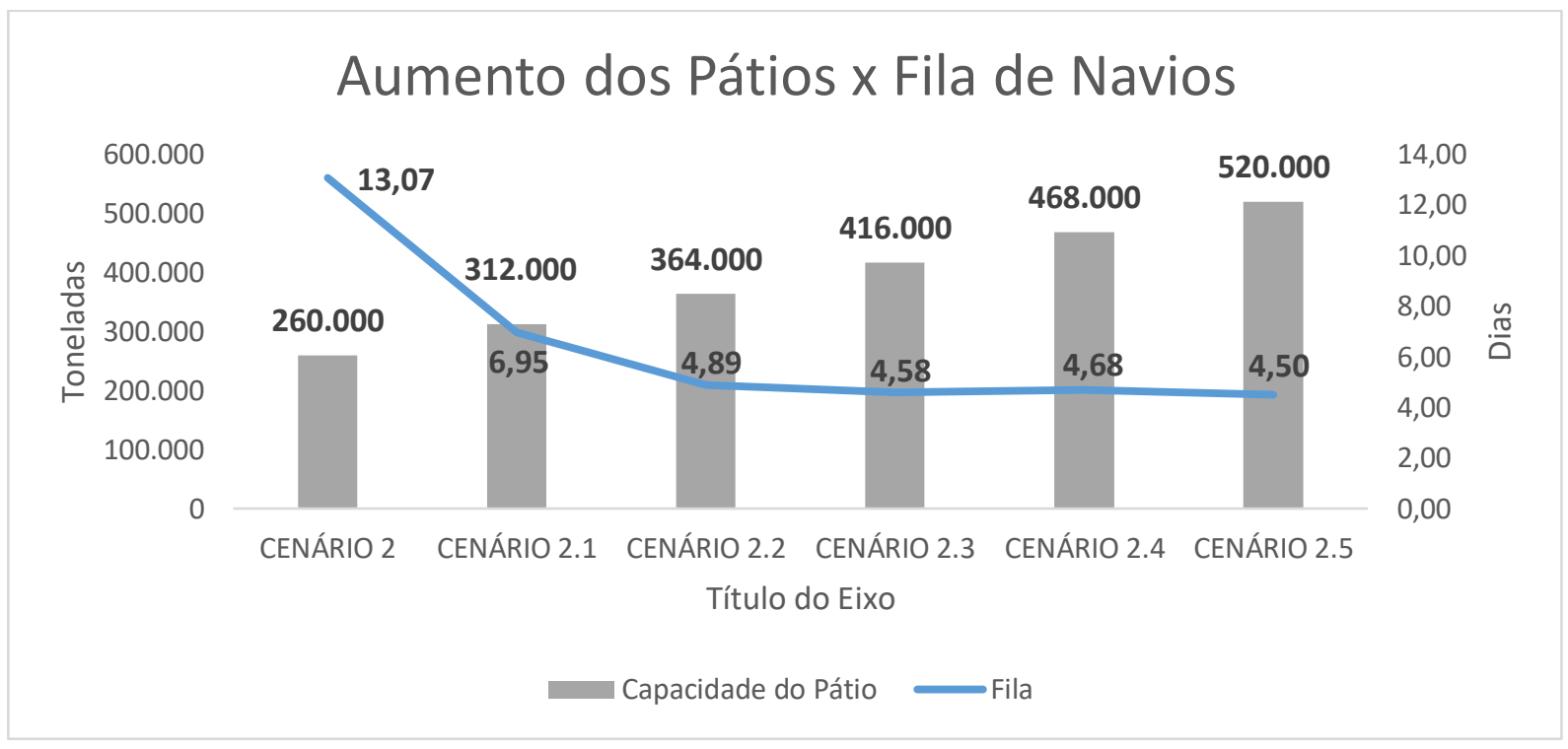

Fonte: Autor

Pode-se observar na Figura 47, que entre o cenário 2.2 e o cenário 2.5 da Tabela 9, a fila de navios praticamente permanece inalterada, mesmo com o aumento significativo do estoque. Isso demostra que, caso a empresa queira aumentar seu nível de serviço e reduzir os custos advindos da alta fila de navios, mantendo a gestão operacional atual, uma opção a ser considerada, seria o aumento do nível de estoque no porto para 364.000 toneladas. 


\section{CONCLUSÃO E RECOMENDAÇÕES}

A utilização da simulação computacional como método para melhorar a capacidade analítica dos problemas em terminais portuários vem se consolidando forte nas empresas e, cada vez mais presente no auxílio a tomada de decisão dos gestores.

Nesse aspecto a utilização da ferramenta de simulação de eventos discretos se mostra uma arma importante, principalmente, quando o assunto é resolver problemas de alta complexidade. O uso científico dessa aplicação contribuiu para a identificação dos gargalos operacionais, possibilitando um maior entendimento de todo sistema logístico e, auxiliando na busca de alternativas e soluções para o problema proposto no estudo.

Portanto, como principal conclusão e recomendação desse estudo, sobre o aspecto de aumentar o nível de serviço, quando associado a capacidade de um sistema portuário, é o uso da simulação de eventos discretos no planejamento operacional de uma cadeia logística integrada. O trabalho mostrou a eficácia de sua aplicação em um ambiente mais amplo e complexo do que pura e simplesmente o desenvolvimento e implementação de um modelo computacional.

Trazendo o objetivo inicial do trabalho para esfera da conclusão e recomendação do estudo, temos a seguinte pergunta. Qual é a melhor forma de receber os produtos no porto de Itaguaí de forma a minimizar a fila de navios no terminal e, aumentar o seu nível de serviço frente a capacidade já instalada do sistema portuário?

Constatou-se nos resultados a importância de verificação constante dos estoques, a partir da queima de matérias primas da Usina e, a necessidade de considerar os diversos lead times por produtos e seus fornecedores nas encomendas dos navios. Essa, portanto, é a melhor maneira de se organizar a chegada de navios no terminal de forma a minimizar o impacto na fila de navios.

Em entrevistas com os profissionais da companhia, que estão inseridos nesse processo, foi possível identificar que o planejamento da Usina se dá através de um plano anual de produção de aço. As datas necessárias para a chegada dos insumos trazidos pelos navios, são informados para área comercial e, a partir dessa informação se inicia as negociações com os fornecedores. Algo importante a se reparar é que, 
caso a área de suprimentos desconsidere a variação dos lead times durante a negociação, algo comum na condução comercial, a variação na chegada desses navios implicará no aumento das filas e, consequentemente, no nível de serviço do terminal.

Outro ponto importante observado durante a pesquisa foi, no intuito de diminuir o custo unitário da tonelada na aquisição dos insumos, identificou-se que a área comercial negocia a compra de 6 a 7 navios do mesmo produto de acordo com o plano inicial da Usina. Acontece que qualquer variação da chegada desses navios no terminal implica em um aumento no estoque e, consequentemente, na fila de navios no terminal.

Deste modo, é preciso envolvimento constante das áreas de interface: usina, porto e comercial, para que as informações disponíveis, como estoque e ritmo de produção, sejam discutidos de forma rotineira e, as tomadas de decisões sejam compartilhadas.

Como sugestão, é importante que a equipe de suprimentos, comercial e a equipe da Usina, tenham em suas metas de trabalho, não só a redução do custo unitário da matéria-prima, mas, também os custos de demurrage advindos da sobreestadia dos navios no terminal.

Uma observação pertinente a esse trabalho, e bem observada durante as entrevistas com as diversas áreas da companhia, é que, pelo fato do controle do custo de demurrage hoje, não ser de responsabilidade da Usina, a mesma parece não se incomodar com essa ineficiência do terminal, visto que, os navios aguardados em fila, funcionam como uma espécie de estoque flutuante no porto.

Por esse motivo também, foi pontuado dois problemas internos da equipe da Usina, o primeiro, a falta de conhecimento do time de planejamento, no que diz respeito, ao entendimento de toda cadeia logística integrada. E o segundo ponto que, os estoques de segurança estão muito acima do nível de incerteza do processo produtivo, o que, demonstra mais uma vez a ausência de entendimento por parte da equipe da Usina.

Como objetivos específicos do trabalho, foi possível avaliar a encomenda dos insumos das usinas alterando o nível de estoque de segurança dos produtos e, através das análises de sensibilidade, foi possível também identificar alternativas de gestão, no intuito de aumentar o nível de serviço no terminal, sem que haja grandes intervenções 
no processo. A encomenda de navios poderá considerar sua chegada no porto com uma cobertura de estoque de apenas 19 dias ao invés de 30 dias. Isso irá permitir que a fila de navios diminua drasticamente de aproximadamente 13 dias para 5,59 dias. Importante reforçar que essa alternativa peremptoriamente necessita de uma integração de todos os stakeholders envolvidos e da verificação constante de todas as variáveis inseridas no processo, criando uma espécie de rotina e retroalimentação do planejamento de abastecimento da Usina.

Esses resultados deverão permitir um entendimento maior de todos e poderá permitir uma mudança de mindset das equipes e dos tomadores de decisões.

Outra análise realizada no modelo, foi a construção de cenários a partir do aumento de capacidade de armazenamento de produtos no porto. Caso a Usina entenda que a redução da cobertura de estoque não seja uma opção viável, a alternativa de investimentos para aumento do estoque no terminal deverá ser discutida no âmbito de projetos para que essa alternativa se viabilize.

E, por fim, sugere-se que essa metodologia seja replicada no âmbito, não apenas em um processo de importação de insumos integrado a uma unidade de produção, mas também em cenários similares onde se tenha a necessidade de avaliar o nível de serviço associado a capacidade de terminais portuários. 


\section{REFERÊNCIAS}

BALLOU, R.H. Gerenciamento da Cadeia de Suprimentos/Logística Empresarial/ 5. Ed. Porto Alegre. 2006.

BRITO, T.B., (2011). Aplicabilidade da Simulação Híbrida em Sistemas Logísticos. Dissertação (Mestrado) - Escola Politécnica da Universidade de São Paulo. Departamento de Engenharia de Transportes. Engenharia de Sistemas Logísticos. São Paulo, 2011

BORTOLOTTO, L. S. 5 Curiosidades sobre filas que você não sabia. Disponível em: <www.zerofila.com.br/blog/mobile/entry/5-curiosidades-sobre-filas-que >. Acesso em 15 nov. 2016.

BOTTER, R.C. Introdução às técnicas de Simulação e ao Programa Arena, PECE, Agosto, 2001.

BOTTER, R.C. Apresentação e trabalhos desenvolvidos. Disponível em: $<$ https://aapa.files.cms-

plus.com/SeminarPresentations/2012Seminars/12LatinAmericanCongress/RUI\%20C ARLOS\%20BOTTER.pdf>. Acesso em 04 mar. 2020.

CAMPOS, Vicente Falconi Campos, TQC - Controle da Qualidade Total (no estilo japonês). Belo Horizonte, Ed. Editora de Desenvolvimento Gerencial, 1999.

CARTONI, D. M. Manual de monografia geral. Valinhos: FAV - Faculdade de Valinhos. Não publicado. 2007.

CHOPPRA, S.; MEINDL, P. Gerenciamento da Cadeia de Suprimentos. São Paulo: Prentice Hall, 2003.

CHWIF, L. Redução de modelos de simulação de eventos discretos na sua concepção: uma abordagem causal. Diss. Universidade de São Paulo. 1999.

CHWIF, L., MEDINA, A.C. Modelagem e simulação de eventos discretos: Teoria e Aplicações. Elsevier, Vol. 4. Rio de Janeiro. 2015.

COELHO, L. C.; FOLLMANN, N.; RODRIGUEZ, C. M. T. O Efeito Chicote e o seu Impacto na Gestão das Cadeias de Suprimentos. Simpósio de Excelência em Gestão e Tecnologia, Resende, Rio de Janeiro, Brasil, v. 4, 2007.

CSN. Companhia Siderúrgica Nacional. Disponível em: <www.csn.com.br $>$. Acesso em: 07 de nov. 2019

DAUDT, T. K. Mensuração do efeito chicote e a sua correlação com os níveis de estoques em uma empresa do ramo siderúrgico. 2014.

Dias, G. P. P. Gestão dos estoques numa cadeia de distribuição com sistema de reposição automática e ambiente colaborativo. Diss. Universidade de São Paulo, 2003. 
FILIPPINI, R., Operations Management Research: Some Reflections on Evolution, Models and Empirical Studies in OM. International Journal of Operations and Production Management, v. 17, n.7, p. 655-670, 1997.

FIGUEIREDO, K., ARKADER, R. Da distribuição física ao supply chain management: o pensamento, o ensino e as necessidades de capacitação em logística. Revista Tecnologística, v. 33, p. 16, 1998.

GROSS, D., HARRIS, C.M. Fundamentals of Queueing Theory. John Willey and Sons, New York, 1974.

GUALDA, N. D. F. Terminais de transportes: contribuição ao planejamento e ao dimensionamento operacional. Tese de Livre Docência. EPUSP. Departamento de Engenharia de Transportes. São Paulo. 1995.

HOUAISS, A., VILLAR, M.S., FRANCO, F.M.D.M. Dicionário da língua portuguesa. Rio de Janeiro, Objetiva, 2001.

IABR. Instituto Aço Brasil. Disponível em: <www.acobrasil.org.com.br>. Acesso em: 07 de nov. 2016.

JULIÁ, A. F. Desenvolvimento de um modelo de simulação para dimensionamento de um sistema integrado pátio-porto na cadeia do minério de ferro. Diss. Universidade de São Paulo, 2010.

LEE, H.; PADMANABHAN, V.; WHANG, S. The bullwhip effect in supply chains. Sloan Management Review, n .38, p.93-102, 1997.

LEE, H. L.; PADMANABHAN, V.; WHANG, S. Information Distortion in a Supply Chain: The Bullwhip Effect. Management Science, v. 50, n. 12, 2004.

LEMOS, R. MODAL MARÍTIMO (Classificação, Portos, Legislação, OMI e etc). Disponível em: <https://logisticaeomundo.wordpress.com/2017/08/13/modalmaritimo-classificacao-portos-legislacao-omi-e-etc/>. Publicado em 13 ag. 2017. Acesso em 29 abr. 2020.

LOURENÇO, T. O impacto do setor do aço no desenvolvimento brasileiro e capixaba. Disponível em: http://esbrasil.com.br/o-impacto-do-setor-do-aco-no-desenvolvimentobrasileiro-e-capixaba/.Acesso em 07 nov. 2016.

MARTINS, G. A. Estudo de caso: uma reflexão sobre a aplicabilidade em pesquisas no Brasil. Revista de Contabilidade e Organizações, v. 2, n. 2, p. 8-18, 2008.

MOTA, D. D. O. Modelagem da programação de navios para otimização no canal de acesso ao porto de santos. Tese de Doutorado. Universidade de São Paulo. 2016.

NETTO, F. J., BOTTER, R.C., MEDINA, A.C. Analysis of capacity associated to levels of service at port terminals using systemic approach and simulation of discrete event. Winter Simulation Conference, California, 2015. 
PEREIRA, N. N. Alternativas de tratamento da água de lastro em portos exportadores de minério de ferro. Tese de Doutorado. Universidade de São Paulo. 2012.

PEREZ-FRANCO, R. Rethinking your supply chain strategy: a brief guide. 2016.

ROCHA, C. F., O Transporte de Cargas no Brasil e sua Importância para a Economia. Dissertação (Ciências Econômicas). ljuí, 2015.

SILVA, R.C.D.S. Análises de tradeoff em sistemas de transporte aquaviário com simulação de eventos discretos. Dissertação (Mestrado). Universidade de São Paulo, 2012.

SILVA, G. R. Desenvolvimento de um modelo de simulação para avaliação do desempenho de uma cadeia de suprimentos multicamadas do ramo de mineração através da adoção da estratégia colaborativa VMI (Vendor Managed Inventory). Dissertação (Mestrado). Universidade de São Paulo, 2010.

SILVA, E. L. D.; MENEZES, E. M. Metodologia da pesquisa e elaboração de dissertação. 3. ED. Florianópolis: UFSC, 2001.

SLACK, N., CHAMBER, S.; HARDLAND, C.; HARRISON, A. JOHNSTON, R. Administração da Produção. São Paulo: Atlas, 1999.

SREE PARIMALA, R.; PALANIAMMAL, S. Bulk service queueing model with servers single and delayed vacation. International Journal of Advances in Science and Technology, v. 2, n. 2, p. 18-24, 2014.

SVENSSON, G., The multiple facets of the bullwhip effect: refined and re-defined. International Journal of Physical Distribution \& Logistics Management. n. 35, 2005.

VERGARA, S. C. Projetos e Relatórios de Pesquisa em Administração. Atlas 3. ED. São Paulo, 2000.

VOSS, C.; TSIKRIKTSIS, N.; FROHLICH, M. Case research in operations management. International journal of operations \& production management, 2002. 


\section{APÊNDICES}

\section{APÊNDICE A - Modelo do documento, Statment of Facts - SOF}

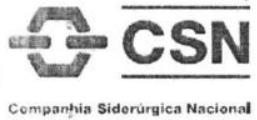

COMPANHIA SIDERÚRGICA NACIONAL.

Estrada da Ilha da Madeira, Porto de Sepetiba

Illha da Madeira - Itaguai - RJ - Cep 23.821-410

Companhia Siderürgica Nacional

E-Mail: sepetiba@csn.com.br

\section{STATEMENT OF FACTS}

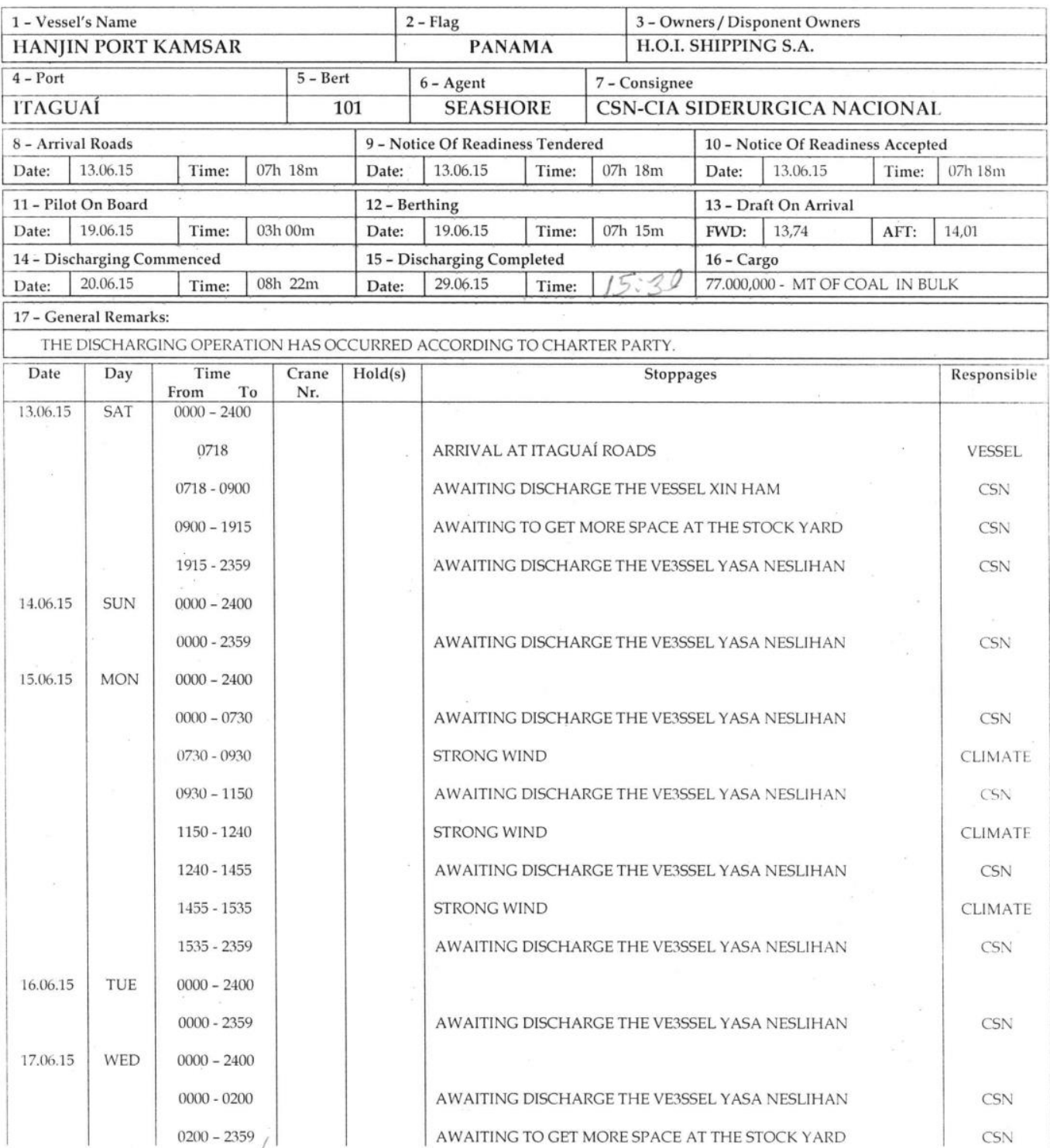

\begin{tabular}{|c|c|c|c|c|}
\hline Agent & Accepled as Indicated Above & Stevedores & Accepted as Indicated Above & Accepted as Indicated Above \\
\hline & 10. & 2 & & $\frac{1}{2} c$ \\
\hline - & $\begin{array}{l}\text { SeaShore Solution's } \\
\text { Com. e Sey. Maritimos Lida. } \\
\text { Roberto Carlos de Araújo Lucas } \\
\text { R. } 799.844 .447 .91\end{array}$ & Rusti & $\begin{array}{l}\text { Oo Sobza da Sifva } \\
\text { Coordenador } \\
\text { G: } 12.222 .562-6\end{array}$ & II NAM \\
\hline
\end{tabular}




\section{(1)韓淮洨逨 HANJIN SHIIPPING}

Hanjin Shipping Bldg, 25-11, Yoido-dong, Youngdeungpo-Ku, Seoul, Korea, Phone: (02) 3770-6770

\section{NOTICE OF READINESS}

Port of Itaguai, Brazil

Date : June 13th, 2015

To Messrs,

Please be hereby officially notified that M.V. HANJIN PORT KAMSAR

of which I am the Master, has arrived at the Port of Itaguai, Brazil

at 0718 hours on June 13th, 2015 and anchored at Itaguai outer anchorage, Brazil

and she is in all respects ready to commence Discharging cargo of Coal

in accordance with the terms and conditions as per governing Charter Party.

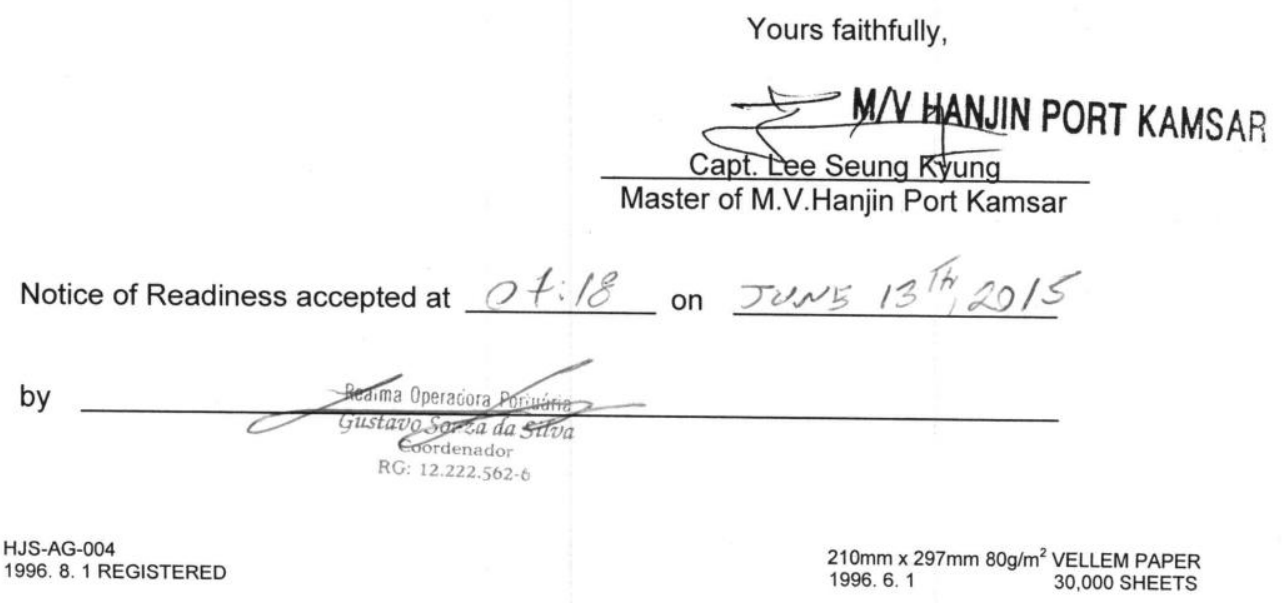


APÊNDICE C - Questionário 1) Processo de Abastecimento UPV

1) Nome da empresa: Companhia Siderúrgica Nacional - CSN

2) Nome do respondente: Leonardo Dutra Coutinho

3) Sua posição dentro da companhia: Gerente de planejamento e Controle da Produção

4) E-mail de contato: leonardo.coutinho@csn.com.br

5) Tempo de atuação no mercado da empresa. a). 1 a 5 anos b). 5 a 10 anos c). 10 a 15 anos d). Acima de 15 anos R: Acima de 15 anos na empresa

6) Poderia descrever suas atividades hoje na sua área de atuação?

Como Gerente de Planejamento e Controle da Produção, gerencio uma equipe responsável no planejamento as atividades envolvendo toda a cadeia logística de minério e carvão (transporte marítimo, ferroviário e rodoviário), controle de inventário dos produtos e operação portuária através do centro de controle operacional onde ocorre a execução do planejamento propriamente dito.

7) Qual sua interação com a gestão do estoque de carvão no Porto de Itaguaí TECAR?

No que tange a gestão de estoque de redutores no TECAR, temos como papel fundamental a atualização das informações necessárias tais como estoque de produto, fila de navios, entre outros que serão suporte para a tomada de decisão dentro do planejamento futuro. Essa gestão é focada mais na operacionalização do planejamento pré-definido pela UPV de forma maximizar a utilização dos operacionais portuários.

8) Poderia descrever o processo de abastecimento da Usina e, qual área faz a gestão do estoque no terminal portuário?

O processo de abastecimento da UPV é puxado através do plano anual de produção de aço. Com base nessas informações, a área técnica responsável pelo suprimento da UPV define qual a melhor mistura de carvão/coque considerando qualidade e custo 
e repassa para área de planejamento da UPV. De posse dessas informações e considerando as capacidades operacionais de estoque na UPV/Porto, ferrovia, rodoviário, estoque de segurança, entre outros indicadores operacionais, é realizado a compra dos redutores no horizonte de tempo, buscando o equilíbrio entre o custo mínimo operacional e o cumprimento do plano de produção anual.

9) Existe hoje algum problema de comunicação entre as áreas de PCP do Porto e de Planejamento da Usinas?

Entendo que o problema existente dentro da gestão de estoque de matérias primas atualmente não seja preponderantemente comunicação. Na minha visão poderia citar três grandes razões para que o resultado da gestão de suprimento de matéria prima ainda não tenha sido eficiente.

Falta de conhecimento dos analistas responsáveis pelo planejamento da UPV em gestão da cadeia de suprimento integrada;

Planejamento não direcionado para eficiência operacional global, onde os estoques de segurança nos pátios internos da UPV/Porto/em trânsito "dentro dos navios", estão muito acima do nível de incerteza do processo produtivo e comprometendo diretamente no nível de serviço Portuário;

Ausência de uma ferramenta capaz de simular/otimizar os cenários prováveis do sistema de forma integrada e prover "insights" para a tomada de decisão de forma mais eficiente.

10) Existe hoje alguma preocupação da área de planejamento da Usina, referente aos custos de demurrage advindos da fila dos navios no processo de descarga de carvão no TECAR? Qual área é responsável pela administração desses custos?

Atualmente o planejamento da UPV tem como "drive" garantir o suprimento da mistura de Carvão/Coque/PCl definida pela área técnica no planejamento anual. Este planejamento tem como premissa manter os estoques de segurança para suprir as variabilidades de todo o processo, porém, infelizmente tem sido visto pela dinâmica estocástica desse conjunto de operações, tais como, problemas operacionais diversos, manutenção corretiva, a variabilidade no lead time, variação no preço da matéria-prima afetando a demanda/oferta, dentre outros fatores, uma elevação dos 
custos de demurrage em alguns momentos bem acima do esperado com consequências comerciais (pagamento de multas a armadores/fornecedores), consequências operacionais (o não cumprimento das condições de fila "FIFO"), em função na não prioridade em realizar um planejamento abrangente que visa minimizar os custos operacionais balanceado com um nível de serviço coerente com a estrutura operacional existente.

Atualmente, o custo de demurrage é gerenciado pela área comercial, o que na minha visão, tem favorecido para uma gestão mais superficial e menos técnica quanto a necessidade de medidas que podem ser adotadas para reduzir esse custo relevante para a operação portuária, a níveis praticados por outras empresas do mesmo segmento. 
APÊNDICE D - Questionário 2) Processo de Abastecimento UPV

1) Nome da empresa: Companhia Siderúrgica Nacional - CSN

2) Nome do respondente: Bruna Moraes Gonçalves

3) Sua posição dentro da companhia: Analista Planejamento Portuário

4) E-mail de contato: bruna.goncalves@csn.com.br

5) Tempo de atuação no mercado da empresa. a). 1 a 5 anos b). 5 a 10 anos c). 10 a 15 anos d). Acima de 15 anos - 5 a 10 anos de empresa

6) Poderia descrever suas atividades hoje na sua área de atuação?

Como analista de Planejamento,sou responsável pelas atividades de programação da cadeia logística dos redutores dentro do Porto de Itaguaí. Essas atividades envolvem, no geral, a programação da fila de navios, bem como a gestão dos estoques dos granéis nos pátios de armazenamento e programação de envio desses materiais para a Usina seja por modal ferroviário.

7) Qual sua interação com a gestão do estoque de carvão no Porto de Itaguaí TECAR?

Sou responsável pelo controle dos estoques físicos e contábeis de redutores do porto.

A partir das informações de chegada de navios e carregamentos solicitados pela Usina elaboramos as projeções de estoques para datas futuras.

8) Poderia descrever o processo de abastecimento da Usina e, qual área faz a gestão do estoque no terminal portuário?

A Usina define seu plano de produção, e de acordo com ele, os redutores que devem ser comprados, para atender a esse plano. A área de suprimentos segue com as negociações e compras, e informa ao porto a possível data de chegada de cada produto (entradas). As etapas do lead time são: 
- Transit time do navio, considerada como sendo o primeiro dia de lay day no porto de origem; Tempo médio de negociação dos navios: 10 dias; Negociação de frete marítimo: em média 30 dias;

A Usina informa ao porto os produtos que devem ser carregados (saídas). A partir dessas informações, o PCP Porto faz a projeção do estoque do terminal portuário, e de acordo com a execução da descarga dos navios e carregamentos ferroviário e rodoviário, faz gestão real dos estoques.

Os tempos de descarga do trem na usina gira em torno de 8 horas e o seu transit time vazio e cheio, no ciclo entre porto e a unidade siderúrgica, em média, está em aproximadamente 6 horas.

9) Existe hoje algum problema de comunicação entre as áreas de PCP do Porto e de Planejamento da Usinas?

O problema atual é a falta de uma programação detalhada de produtos a serem enviados para a usina mensalmente, o que dificulta uma programação mais precisa do restante da cadeia, principalmente a projeção mais precisa dos estoques.

10) Existe hoje alguma preocupação da área de planejamento da Usina, referente aos custos de demurrage advindos da fila dos navios no processo de descarga de carvão no TECAR? Qual área é responsável pela administração desses custos?

Existe uma preocupação com demurrage, pois toda gestão da programação dos navios é feita de forma a reduzir o tempo de espera em fila e, consequentemente, os custos de demurrage. Porém, o fator mais importante para usina é ter um estoque de segurança confortável, de forma que isso se sobrepõe à preocupação com os gastos de demurrage.

Alguns problemas adicionais à questão das solicitações de insumos, pela área de planejamento da Usina, são as compras realizadas pela equipe comercial da empresa onde, para se ter melhores condições comerciais, muitas das vezes negociam a encomenda de 7 a 10 navios, por exemplo, do mesmo produto. Essa negociação pelo lado financeiro, há uma redução no preço, porém, implica em uma chegada de navios com o mesmo produto em um menor intervalo de tempo, aumentando o estoque e dificultando a descarga de outros navios, por falta de espaço nos pátios. 